UNIVERSIDADE DE SÃO PAULO

FFCLRP - DEPARTAMENTO DE PSICOLOGIA E EDUCAÇÃO

PROGRAMA DE PÓS-GRADUAÇÃO EM PSICOLOGIA

\title{
BRUNO DE PAULA ROSA
}

\section{Jovens solteiros: identidade, subjetividade e concepções acerca do casamento}

Dissertação apresentada à Faculdade de Filosofia, Ciências e Letras de Ribeirão Preto da USP, como parte das exigências para a obtenção do título de Mestre em Ciências, Área: Psicologia.

RIBEIRÃO PRETO

2010 



\section{BRUNO DE PAULA ROSA}

\section{Jovens solteiros: identidade, subjetividade e concepções acerca do casamento}

Dissertação apresentada à Faculdade de Filosofia, Ciências e Letras de Ribeirão Preto da Universidade de São Paulo para a obtenção do título de Mestre em Psicologia

Área de Concentração: Psicologia

Orientador: Prof. Dr. Geraldo Romanelli

RIBEIRÃO PRETO

2010 
Autorizo a reprodução e divulgação, total ou parcial deste trabalho, por qualquer meio convencional ou eletrônico, para fins de estudo e pesquisa, desde que citada a fonte.

\section{FICHA CATALOGRÁFICA}

Rosa, Bruno de Paula

Jovens solteiros: identidade, subjetividade e concepções acerca do casamento. Ribeirão Preto, 2010.

141 p. : il. ; $30 \mathrm{~cm}$

Dissertação de Mestrado, apresentada à Faculdade de Filosofia, Ciências e Letras de Ribeirão Preto/USP. Área de concentração: Psicologia.

Orientador: Romanelli, Geraldo.

1. Homens. 2. Identidade. 3. Subjetividade. 4. Masculinidade.

5. Casamento. 
ROSA, B. P. Jovens solteiros: identidade, subjetividade e concepções sobre o casamento. Dissertação apresentada à Faculdade de Filosofia, Ciências e Letras de Ribeirão Preto da Universidade de São Paulo para a obtenção do título de Mestre em Psicologia.

Aprovado em:

Banca Examinadora

Prof. Dr.

Instituição:

Julgamento:

Assinatura:

Prof. Dr.

Instituição:

Julgamento:

Assinatura:

Prof. Dr.

Instituição:

Julgamento:

Assinatura: 

Aos meus avós, Geraldo e Maria, José Amado (in memorian) e Maria (in memorian), com muito amor, admiração e saudades... 



\section{AGRADECIMENTOS}

A construção desta dissertação teve a contribuição de muitas pessoas que, de uma forma ou outra, cruzaram o meu caminho. Algumas delas já estavam comigo desde sempre, desde a infância, a adolescência, a graduação, o início do mestrado, outras delas passaram a fazer parte ao longo deste processo. Sou muito grato por cada fala, cada gesto, cada olhar, por tudo que pude aprender, compartilhar, sentir, pensar e vivenciar, perto ou longe de cada um de vocês.

Ao meu orientador, Prof. Geraldo Romanelli, pelos anos de convivência e por mais uma vez aceitar embarcar comigo rumo às aventuras da pesquisa, pela confiança depositada em meu trabalho e minhas capacidades. Pela disposição em sempre sanar minhas dúvidas e inquietações e pelas palavras tranquilizadoras e pelo incentivo em sempre continuar em frente. Pelas caronas sempre após cada supervisão, recortadas por conversas tão importantes para minha formação.

Ao meu querido pai, José Roberto, por encher de música a minha vida e por me ajudar a perceber o quão rico pode ser o encantamento diante de certas simplicidades da vida.

À minha querida mãe, Mariana, por me mostrar outras perspectivas sobre a vida e pelos conselhos que tanto me enriqueceram e me abriram novos caminhos.

À minha grande companheira e irmã, Brenda, por me ensinar a vislumbrar certas situações de formas engraçadas, por me surpreender com suas mudanças e perceber que, mesmo tão diferentes, podemos nos divertir tanto com tão pouco.

À Theo, pela parceria em análise e por me acompanhar na experiência da busca de mim mesmo, pela disposição emocional em acolher minhas angústias, pelo compartilhar tão genuíno e por me ajudar a me enxergar que o conhecimento de mim é algo custoso, mas muito útil. Obrigado por tudo.

À Mari, por todo o amor, pela docilidade que torna a minha vida mais plena, por sonhar junto comigo, pela paciência com as minhas inquietações e por me ensinar tanto sobre o nosso relacionamento. Amo você, minha flor.

Aos meus amigos e companheiros de república, Sujeito, Dani, Lucão e Frodo, por tantas boas lembranças, conversas e risadas que não tiveram lugar nem hora para acontecer, por me ensinarem que grandes amizades precisam ser adubadas com muita confiança e respeito.

Ao Barão, pelo incentivo insistente para o ingresso no mestrado no final do quinto ano de graduação e pelo companheirismo em disciplinas, longas e inesquecíveis discussões. Aos companheiros de grupos de pesquisa Du, Pedro e Felipe, pela disposição e ajuda oferecidas sempre que as solicitei.

Aos Profs. Drs. Sócrates Nolasco e Marko Monteiro, pelas críticas e contribuições valiosíssimas e desafiadoras ao meu trabalho, que me impulsionaram ao estudo, à reflexão e deixaram entrever detalhes importantes a serem valorizados na pesquisa. 

Aos professores e colegas que me acompanharam no Mestrado, pela troca de conhecimentos, experiências e por trazerem indagações tão pertinentes ao meu cotidiano.

Aos meus avós, tios e primos, minha família, cujos encontros me fazem sentir que a beleza da vida está também na possibilidade de estarmos juntos e unidos. Por todos os momentos que me aquecem o coração.

Aos meus eternos amigos de colégio, por existirem e permanecerem em meu caminho e, apesar da distância, estarem tão próximos. Por me fazerem acreditar que longas e verdadeiras amizades são possíveis e lapidadas com o tempo e as intempéries da vida.

À Grazi, Naná, Junia, Keilla, Carlos, Luciana e aos meus amigos que vejo pouco, mas significam muito, pela fidelidade ao longo destes anos.

Aos meus companheiros do LEO Clube, pela hospitalidade, pela amizade sincera, por vivenciarem comigo momentos, eventos e viagens que me acrescentaram muito. De forma particular, ao Danilo, Dersão, Paty, Joyce, Cristian e os meus sempre queridos dos LEO Clubes de Passos e Ribeirão Preto. Aqui dentro cabem muitas lembranças indeléveis.

Aos meus colegas de trabalho da Defensoria Pública, principalmente à Renata, Felipe, Marcelo, Marquinho, Fer, Rita, Raphael e João, pela companhia e parceria diárias.

À Fundação de Amparo à Pesquisa do Estado de São Paulo, pelo auxílio financeiro ao longo do desenvolvimento da pesquisa, sem o qual esta caminhada não seria possível.

Ao meu padrinho, Benedito, pela ajuda mais do que útil de última hora e pelo carinho de sempre.

Aos funcionários da Faculdade de Filosofia, Ciências e Letras de Ribeirão Preto, pelo esclarecimento de minhas dúvidas e respeito com que sempre me atenderam.

E, de modo mais do que especial, aos participantes desta pesquisa, que aceitaram dividir comigo sua vida, suas opiniões, concepções, planos e sonhos. Por desvelarem a mim suas dificuldades, seus medos, necessidades e desejos. Meu profundo respeito e minha consideração a vocês, sempre.

Enfim, minha gratidão à vida, que me permitiu tantos encontros transformadores nesta jornada. 
O menino é o pai do homem.

William Wordsworth 



\section{RESUMO}

ROSA, B. P. Jovens solteiros: identidade, subjetividade e concepções acerca do casamento. 2010, 141 f.. Dissertação (Mestrado). Faculdade de Filosofia, Ciências e Letras de Ribeirão Preto, Universidade de São Paulo, Ribeirão Preto, 2010.

Historicamente, a família vem passando por transformações e atualmente é difícil defini-la, pois ao lado da família nuclear - composta por pai, mãe e filhos - há várias outras configurações: famílias monoparentais, ampliadas, recompostas, casais homossexuais com filhos de relações anteriores ou adotados. Tal variedade de arranjos domésticos afeta relações familiares, espaços sociais ocupados por homens e mulheres e, por conseguinte, a própria posição masculina na família e na sociedade. A proposta deste projeto de pesquisa foi investigar como homens heterossexuais solteiros de camadas médias, de 25 a 35 anos, concebem sua masculinidade, como vivenciam e expressam seus sentimentos, as expectativas a respeito de relacionamentos afetivosexuais, suas concepções sobre casamento e a constituição de uma família. Foram entrevistados dez jovens, residentes na cidade de Ribeirão Preto - SP, com idades entre 26 e 31 anos. A coleta de dados foi realizada através de entrevistas semi-estruturadas gravadas e transcritas na íntegra e os dados foram analisados à luz de referenciais teóricos antropológicos e psicológicos. Tornar-se homem relaciona-se diretamente com assunção das responsabilidades esperadas do sexo masculino e a figura do provedor está ligada a duas esferas concretas: trabalho e família. $\mathrm{Na}$ construção da identidade masculina, relacionamentos com familiares e amigos, independência financeira e emocional em relação aos pais e valores como honestidade, responsabilidade, respeito e ética foram os aspectos mais citados. Conquistas pessoais, profissionais, materiais, afetivo-sexuais e a convivência com amigos do mesmo sexo foram apontadas como elementos positivos em suas vidas. Já fracassos pessoais e profissionais, dificuldades em relacionamentos com mulheres trazem à tona sentimentos de temor, relacionados inclusive com traição nas relações afetivas, com perda da virilidade e de impotência sexual. Os participantes apontaram como principal diferença entre homens e mulheres o lado racional masculino em contraposição ao lado emocional feminino. De modo geral, disseram se sentir muito bem sendo solteiros e assinalam como a maior vantagem dessa condição o fato de terem menos responsabilidades a assumir - especialmente para aqueles que ainda moram com os pais - o que possibilita acumular mais dinheiro para ser investido em planos futuros, como o próprio casamento. Para alguns deles, o casamento está diretamente ligado à constituição de uma família e à chegada de filhos. A maioria dos participantes mencionou o propósito de se casar e todos manifestaram o desejo de serem pais, inclusive aqueles que têm pais separados e não têm contato com o genitor. Observam-se dificuldades para conciliação de estereótipos sociais solidificados com novas identidades masculinas e femininas e sobre o que é exclusivo dos homens, uma vez que papéis masculinos e femininos estão mais próximos e muitas vezes se confundem. A expressão afetiva ainda está impregnada de preconceitos e restrições, entretanto se nota por parte dos entrevistados um maior contato com seus sentimentos. O casamento civil e religioso não possui valor imprescindível, contudo a união com a atual namorada ou com uma companheira futura é considerada fundamental para a construção da sua identidade enquanto homem.

Palavras-chave: Homens. Subjetividade. Masculinidade. Casamento. 



\begin{abstract}
ROSA, B. P. Single young men: identity, subjectivity and conceptions about marriage. 2010, 141 f.. Dissertação (Mestrado). Faculdade de Filosofia, Ciências e Letras de Ribeirão Preto, Universidade de São Paulo, Ribeirão Preto, 2010.

Historically, the familial institution has been going through modification and nowadays it's difficult to define it because, besides the nuclear family - composed by father, mother and children - there are many other configurations: mono-parental families, extended families, recomposed families, homosexual couples with children of other relationships or adopted. This variety of domestic arrangements affects familial relations, social spaces occupied by men and women and consequently the male's function in the family and society. The proposal of this search project was to investigate how single heterosexual men of middle class, from 25 to 35 years old, conceptualizes their masculinity, how they live and express their feelings, the expectations about affective-sexual relationships, conceptions about marriage and the constitution of a family. Ten young men, from 26 to 31 years old, residents of the city of Ribeirão Preto - SP, were interviewed. The survey was made through semi-structured interviews recorded and transcribed word by word. The data were analyzed under the anthropological and psychological referential. Becoming a man is directly related to the assumption of male's expected responsibilities and the provider's role is related to the concrete dimensions of work and the family. In the male's identity construction, relationships with family and friends, financial and emotional independence towards to parents and standards as honesty, responsibility, respect and ethic were the most chosen aspects. Personal, professional, material, affective-sexual accomplishments and friendship with male friends were pointed out as positive elements in their lives. Regarding personal and professional failures, difficulties in relations with women bring fear of betrayal in affective relationships, that might cause loss of virility and sexual impotence. The participants pointed male rationality in contraposition to female emotionality as the main difference between men and women. Generally they prefer to be single and mentioned the fact of having less responsibilities to assume as the biggest advantage of this condition - especially for those who still live with their parents - what allows them to save money to be invested in future plans. For some, marriage is directly related to family's constitution and to have kids. Most of the participants mentioned the intention to get married and all of them manifested the desire of parenting, including those who have divorced parents and don't have contact with their progenitors. There are difficulties to conciliate solidified social stereotype with new male and female identities and to distinguish exclusive aspects of men, because male and female roles are intertwined and sometimes become confused. Among the participants the expression of affection is still impregnated with prejudice and restrictions however is notable a great contact with their own feelings. The civil and religious marriage don't have an essential value, nevertheless the union with the actual girlfriend or with a future partner is considered very important to the construction of male's identity.
\end{abstract}

Key words: Men. Subjectivity. Masculinity. Marriage. 



\section{SUMÁRIO}

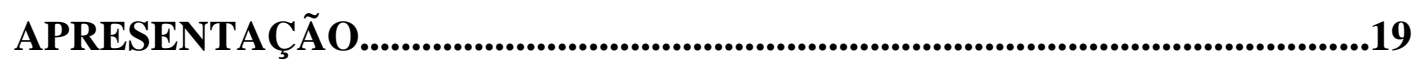

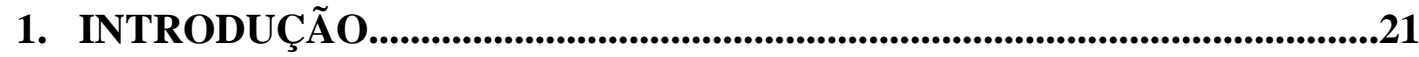

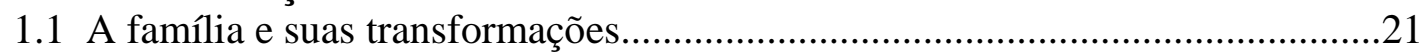

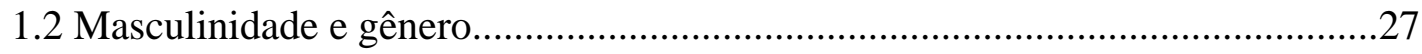

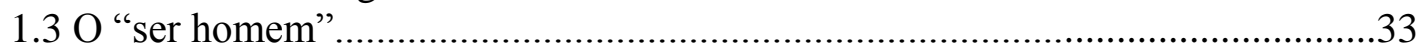

1.4 A construção da subjetividade masculina e a crise da masculinidade .................40

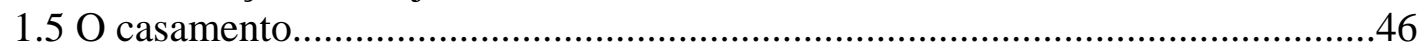

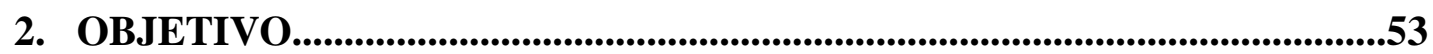

3. METODOLOGIA......................................................................................55

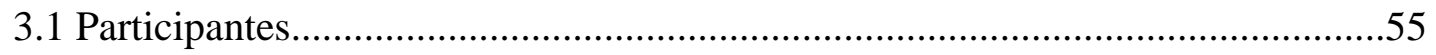

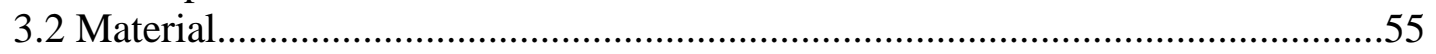

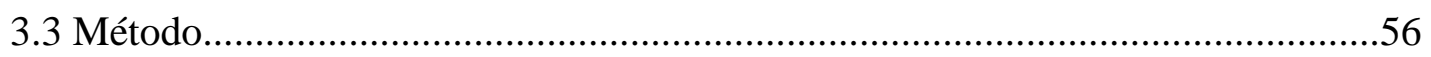

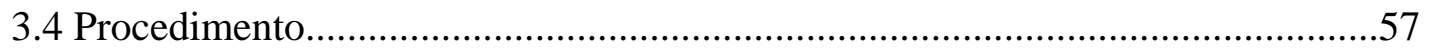

4. RESULTADOS E DISCUSSÃO_............................................................59

4.1 Infância e Adolescência...................................................................................60

4.2 A condição masculina....................................................................................66

4.3 As vivências masculinas...............................................................................73

4.4 As melhores (e as piores) situações da vida de um homem....................................76

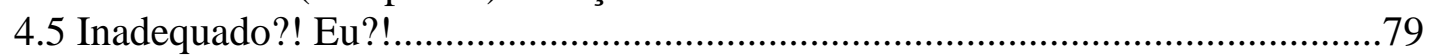

4.6 As delícias e as dificuldades da relação entre homens e mulheres........................81

4.6.1 A objetividade masculina $\mathrm{x}$ os "rodeios" femininos......................................82

4.6.2 É a mulher quem decide?A mulher atual, pela voz deles................................84

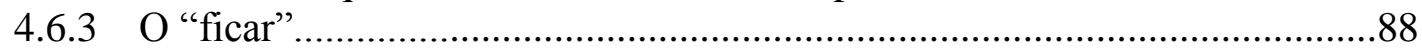

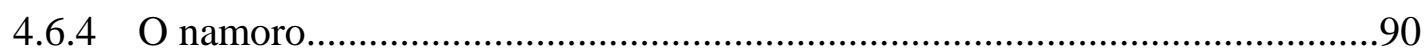

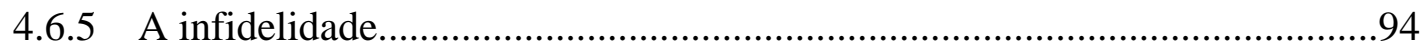

4.7 A relação com os amigos...................................................................................96

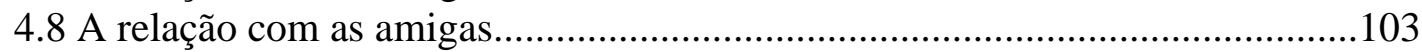

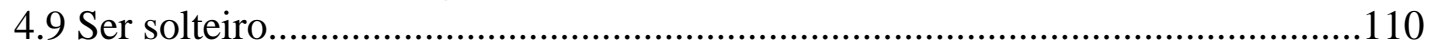

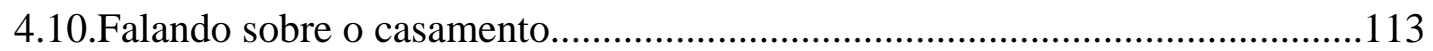

4.11.Ser macho, ser homem, homossexuais e travestis .......................................119

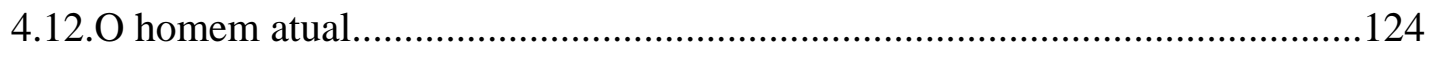

5. CONSIDERAÇÕES FINAIS............................................................................129

REFERÊNCIAS BIBLIOGRÁFICAS..........................................................133

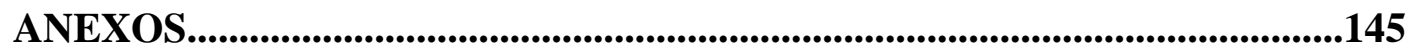




\section{APRESENTAÇÃo}

O interesse por pesquisar a masculinidade surgiu primeiramente durante meu quinto ano de graduação em Psicologia na Faculdade de Filosofia, Ciências e Letras de Ribeirão Preto - FFCLRP/USP, quando tive a oportunidade de participar do Projeto Rondon - Operação Nordeste 2007, na cidade de Aramari - BA, durante o mês de janeiro. Foi certamente umas das experiências mais marcantes ao longo da faculdade. Extrapolar os limites dos muros da Universidade se configurou em um choque de realidades extremamente benéfico - e necessário - para que eu pudesse, a partir dele, começar a traçar meus rumos profissionais.

Ao longo da operação, a equipe da qual eu fazia parte visitava comunidades rurais e realizava várias oficinas, visando sempre adequá-las às necessidades apresentadas por aquelas pessoas. Uma das oficinas executadas por nós tratava de Métodos Contraceptivos. E um dos aspectos que mais chamavam a nossa atenção era que a quase totalidade dos participantes destas oficinas era composta por mulheres. Os homens ficavam do lado de fora da sala e, ao serem convidados a participar, respondiam que não precisavam daquela "aula" (sic), uma vez que já sabiam como "funcionava o negócio" (sic). O mais interessante era observar que muitos deles, quando questionados a respeito de formas de contracepção, não respondiam, ou desafiados a colocar um preservativo em uma prótese peniana, não sabiam como fazê-lo!

Aquela postura me intrigou. Os homens daquelas comunidades pareciam ter muita dificuldade de se aproximar de aspectos da intimidade sexual e se escondiam atrás de um tão aclamado discurso que, testado, expunha a sua própria ignorância. Fiquei me indagando que valores, modelos e ideias estavam embutidos na construção da identidade e dos relacionamentos daqueles homens, especialmente com seus familiares, seus pares e com as mulheres.

Ali, durante aqueles quentes dias de janeiro, sob o sol e o calor da Bahia, era gerado o embrião deste projeto de pesquisa. 


\section{INTRODUÇÃO}

\subsection{A família e suas transformações}

Segundo Lévi-Strauss (1956), a família pode ser entendida como uma união mais ou menos duradoura e socialmente aprovada, entre um homem, uma mulher e seus filhos, que estaria presente em todo e qualquer forma de sociedade. Nessa perspectiva, a família se referiria a um grupo social dotado de ao menos três características: é originária do casamento; é formada pelo marido, esposa e filhos; e seus membros estão ligados entre si por laços legais, direitos e deveres econômicos, religiosos ou de outra natureza, uma união definida por direitos e proibições de ordem sexual, divisão sexual do trabalho e uma variedade de sentimentos psicológicos - amor, respeito, medo, entre outros.

Em praticamente todos os lugares do mundo e ao longo da história, a família vem sofrendo diversas transformações. No Brasil, como em vários outros países, por exemplo, é até mesmo difícil defini-la, tal a multiplicidade de arranjos que pode assumir, desde a família nuclear - composta por pai, mãe e filhos - até várias outras configurações. A partir dos anos 1970, apesar da dominância do modelo nuclear começam a despontar novas formas de conjugalidade. Cresce o número de vínculos afetivo-sexuais variados e de mulheres que escolhem serem mães fora da união legal do casamento.

Há também uma ampliação do número de pessoas que vivem sozinhas e de famílias chefiadas por mulheres, especialmente devido ao aumento das taxas de separações e divórcios. Também contribui para esse índice a maior expectativa de vida feminina, o que ocasiona maior volume de viúvas e de mulheres solteiras com filhos, não só por abandono dos homens, mas como opção das mulheres (CASTELLS, 1999)

A união consensual, ou coabitação sem vínculos legais, como uma alternativa ao casamento passa a ser mais expressiva numericamente, além de ser aceita legal e socialmente. O tamanho das unidades domésticas tende a encolher, com a diminuição do número de filhos devido à queda da taxa de fecundidade feminina. Ao mesmo tempo aumenta o número de recasamentos, de famílias ampliadas, recompostas, e de casais homossexuais com filhos de relações anteriores ou adotados. As famílias ampliadas são 
constituídas pelo casal, filhos e parentes diversos (BILAC, 1991); as famílias recompostas são formadas por parceiros em segunda união, e com filhos de casamento anterior (POITEVIN, 2006; THÉRY, 1993).

Apesar das variações nas formas de arranjos, a família se apresenta como unidade de reprodução biológica e social, responsável pela procriação e pela socialização dos filhos (BOURDIEU, 1997; DURHAM, 1983). A família é constituída pelo casamento legalizado ou por uniões consensuais, que criam relações de aliança ou de afinidade entre um homem e uma mulher. Para Lévi-Strauss (1956), o casamento, portanto, assume importância fundamental, uma vez que é através dele que se criam novas famílias.

Nesse sentido, torna-se importante analisar as mudanças que vêm ocorrendo nos padrões de casamento e na duração do vínculo conjugal.

Transformações substanciais vêm acontecendo dentro do núcleo familiar, relacionadas à alteração da posição relativa da mulher, aos novos padrões de relacionamento entre os membros da família, ao aumento de separações conjugais, à redução no número de casamentos e ao crescimento de uniões livres ou consensuais, isto é, sem casamento civil (BERQUÓ, 1998).

Essa variedade de modificações afeta os contornos do núcleo familiar e, por conseguinte, os lugares sociais ocupados por homens e mulheres dentro da família. Um sustentáculo da masculinidade, a figura patriarcal - símbolo do poder masculino - é um dos mais afetados por essas transformações.

O patriarcalismo, definido como o poder efetivo e socialmente sancionado pela figura paterna no núcleo familiar (OLIVEIRA, 2004), estabeleceu-se de forma indiscutível durante séculos, abrangendo espaços bem mais amplos do que o próprio núcleo familiar. Para Castells (1999), é uma das estruturas sobre as quais se erigiram as sociedades contemporâneas, em que prevalece a autoridade imposta do homem sobre a mulher e filhos dentro da família. E para que essa autoridade fosse exercida, foi necessário que o patriarcalismo se inserisse na sociedade, na política, na cultura, assim como nos relacionamentos interpessoais, inscritos com a violência e dominação oriundas da cultura e das instituições patriarcais.

Uma vez que patriarcalismo e a dominação exercida pelo homem estão estreitamente relacionados, mudanças no primeiro podem ser sentidas na forma como se expressa a masculinidade. Entre essas transformações, se encontram as tendências para 
modificações na estrutura familiar, formada até então por esposa e filhos em torno da figura do marido ou do pai.

Em um mundo com famílias nucleares, recompostas, ampliadas, monoparentais, chefiadas por mulheres e de casais homossexuais, o cenário familiar ainda se apresenta como um lugar privilegiado de circulação do amor e, por conseguinte, de construção da identidade pessoal e social dos indivíduos. Para Singly (2007), a família busca solidificar o "eu" de crianças e adultos; essa consolidação do "eu" é permeada pelo olhar de outras pessoas, como pais, parentes e parceiros, que exercem influência uns sobre os outros.

$\mathrm{Na}$ Europa, essa lógica individualista e relacional surge em substituição à lógica grupal, presente no início do século XX aos anos 1960 e alicerçada no amor e na afeição, em que os adultos estão a serviço do grupo e especialmente das crianças. Ao pai cabia prover e sustentar a casa e a família com o seu trabalho, ao passo que a mulher devia ficar em casa para cuidar dos filhos e do marido, assegurando a felicidade de cada um deles.

As famílias atuais rompem com esse arranjo familiar anterior, na medida em que há uma importância substancial dada ao processo de individualização, deslocando o centro do grupo reunido para os membros que o compõem. A família passa a ser, então, um espaço privado a serviço do indivíduo. Valorizar os espaços individuais implica muitas vezes fragilizar a conjugalidade e vice-versa (SINGLY, 2000).

Segundo os dados da Pesquisa Nacional de Demografia e Saúde da Criança e da Mulher (2006), há cerca de 54,6 milhões de domicílios no país. A modalidade de arranjo domiciliar mais encontrada no Brasil é o de casal com filhos, respondendo por 47,56\% dos domicílios. Considerando juntamente com este arranjo a existência de outras pessoas (parentes ou não-parentes) residindo com a família no mesmo domicílio, ainda se observa que o arranjo domiciliar casal com filhos se apresenta como maioria no país $(58,68 \%)$. O segundo tipo de arranjo domiciliar mais comum no país é o monoparental feminino (12,33\%), superando em muito o do tipo monoparental masculino $(1,96 \%)$.

Os domicílios compostos por apenas um indivíduo ou unipessoais perfazem $8,67 \%$ e destes, $66 \%$ são constituídos por mulheres vivendo sozinhas. Mais de $25 \%$ dos domicílios unipessoais são formados por mulheres acima de 65 anos, ao passo que $8,1 \%$ destes domicílios são compostos por homens desta mesma faixa etária. 
Grande parte dos domicílios no Brasil $(67,8 \%)$ tem como responsáveis pessoas maduras, na faixa etária de 30 a 64 anos; destes, 17,2\% são jovens até 29 anos e 15\% são idosos, com idade igual ou superior a 65 anos. Em relação ao sexo do responsável pelo domicílio, 22,4\% dos domicílios brasileiros são chefiados por mulheres.

Transformações também na composição da força de trabalho contribuem para a emergência de novas atribuições dentro das famílias. Cada vez mais as mulheres se inserem no mercado de trabalho, assumindo funções e alterando a dinâmica de poder dentro da família, uma vez que esta depende também dos rendimentos femininos para se sustentar.

Desse modo, com a participação cada vez maior dos salários das mulheres no orçamento familiar, a idéia do exercício da dominação e de privilégios pelo provedor masculino ficou bastante enfraquecida. (OLIVEIRA, 2004)

Mudanças nos padrões de casamento e em sua duração foram documentadas pelo Instituto Datafolha, em pesquisa realizada em outubro de 2007. Atualmente 49\% da população brasileira são casados e os solteiros correspondem a 37\% dos brasileiros; esses índices permaneceram estáveis em relação à pesquisa anterior, realizada em 1998.

Já o percentual de divorciados subiu de $8 \%$ para $9 \%$ e o de viúvos seguiu em $6 \%$. A pesquisa em questão considera somente aqueles que possuem ou já possuíram relacionamento matrimonial. Segundo o mesmo levantamento, os casamentos têm a duração média de 16 anos e 2,7 filhos por família (FOLHA DE SÃO PAULO, 07/10/2007)

Entre 1998 e 2007, o percentual de pessoas que se casaram em cartório ou na igreja caiu de $55 \%$ para $44 \%$. Vem ganhando cada vez mais importância no Brasil o número de casamentos não legalizados, a coabitação sem vínculos legais. Houve também um declínio na quantidade de uniões apenas religiosas, mas que ainda são valorizadas especialmente em contextos marcados pela ausência de cartórios de registro civil (DATAFOLHA, 07/10/2007).

A mesma pesquisa ainda registrou que $24 \%$ dos solteiros ainda moram com os pais - 65\% têm nível médio e 15\% têm nível superior. A maior parte (59\%) dos solteiros que moram com os pais é de homens e a média de idade nesse grupo é de 23 anos. Há ainda solteiros que moram com filhos ou que dividem a casa com os filhos e com seus pais (2\% em ambos os casos) e ainda aqueles que moram com outras pessoas (5\%).

O percentual de solteiros que já foi casado ou que já viveu com alguém é de 17\%. Entre os solteiros que moram com outras pessoas, que não sejam seus pais nem 
seus filhos, $56 \%$ são homens e $44 \%$ são mulheres, e a idade média é de 28 anos. Os homens também são maioria entre os que moram sozinhos: são 59\% dos que integram esse grupo, no qual a idade média é de 48 anos.

Aproximadamente $69 \%$ dos brasileiros consideram a família a instituição mais importante do país. Em 1998, a família aparecia empatada com os estudos (61\%), os quais foram considerados muito importantes por $65 \%$ dos brasileiros em 2007. Em seguida vieram o trabalho (58\%), a religião (45\%), o lazer (32\%), o casamento $(31 \%)$ e o dinheiro (30\%). Em 1998, o dinheiro (36\%) era considerado mais importante que o casamento (31\%) (DATAFOLHA, 07/10/2007).

Já a pesquisa do IBOPE Mídia a respeito do homem do século XXI traz que, entre os homens brasileiros, $44 \%$ são casados e $31 \%$ dos brasileiros casados têm até 34 anos. Além disso, há mais homens solteiros no país (50\%) do que mulheres solteiras (42\%). De acordo com essa mesma pesquisa, 12\% dos homens de 25 anos ou mais moram sozinhos e, apesar de serem independentes financeiramente, $61 \%$ deles afirmam preferir morar com os pais (IBOPE, 2007). Apesar dessas mudanças, os dados da pesquisa do Instituto Datafolha revelam que se há queda no número de casamentos legalizados, ou da nupcialidade legal, o aumento de uniões consensuais sugere a importância de se constituir família, o que indica a vitalidade da instituição doméstica.

Entretanto, ainda que ocorram essas mudanças significativas, traços de relacionamentos tradicionais ainda se fazem presentes. $\mathrm{O}$ modelo antigo concebia os dois sexos como "naturalmente" biopsicossocialmente distintos, as identidades masculinas se encontram delimitadas com precisão: ao homem cabe a esfera pública, à mulher, o espaço doméstico. A função masculina está associada ao trabalho, à virilidade e ao sustento familiar, o casamento é considerado uma instituição indissolúvel e diretamente ligado à reprodução. No novo modelo, as identidades de homens e mulheres são fluidas, há uma presença marcada do individualismo, o casamento carrega consigo a sua dissolução, expressa pelo descomprometimento entre os parceiros, separações e divórcios, a sexualidade está desvinculada da reprodução.

Para Negreiros e Féres-Carneiro (2004), os dois modelos de relação - o antigo e o novo - não foram completamente incorporados, já que o primeiro não foi vivido de forma original, em função das transformações ocorridas ao longo da história nos papéis de homens e mulheres e o segundo não se consolidou de fato - por exemplo, a assunção do papel de provedora pela mulher não foi acompanhada por novos papéis domésticos assumidos pelo homem. 
Para Negreiros e Féres-Carneiro (2004), o incômodo com essa posição é proveniente da ambivalência em relação aos dois modelos, em que se percebe que os comportamentos tradicionais se mostram inadequados diante da realidade atual, ao passo que as posturas que os substituíram não o fizeram a contento.

$\mathrm{Na}$ sociedade em que vivemos, para alguns autores, os indivíduos são competitivos, consumistas, adotando uma forma hedonista e materialista em que viver é buscar sensações prazerosas e imediatas, sem preocupações com as formas e as consequências.

Lasch (1991), por exemplo, denuncia a estrutura e a dinâmica precárias da família, que espelha a situação da sociedade como um todo, criando uma sensação de ameaça e tornando a vida social um estado de guerra disfarçado de uma cooperação amistosa. Nesse contexto, abre-se espaço para a emergência de rupturas, de relacionamentos efêmeros e superficiais. A antiga família extensa, composta por avós, pais, filhos, netos, tios, sobrinhos e demais membros da parentela se converteu em um pequeno núcleo, formado por pais e filhos, mães e filhos, casais sem filhos. As relações se mostram descartáveis e sem importância, passíveis de serem substituídas com facilidade.

Para Negreiros (2002), em meio a esse panorama de transformações aceleradas, já não há um lugar social definido para os mais velhos. Se em épocas passadas os valores e os papéis se construíam com base nas gerações precedentes, hoje se observa que são os jovens que passam a ser imitados pelos mais velhos, na prática de exercícios físicos, no culto ao corpo, no vestuário.

Não é também assegurado aos mais velhos a rede de apoio após a aposentadoria do trabalho ou a saída dos filhos de casa. Os adultos, inseridos no mercado de trabalho e preocupados em produzir e consumir, não têm disponibilidade para o cuidado dos idosos nem das crianças. Ainda que o cuidado esteja mais ligado à esfera feminina, as mulheres também não cumprem essa tarefa, uma vez que também trabalham. Desse modo, creches, escolas, hospitais, asilos, casas de repouso acabam absorvendo e acolhendo, segundo Negreiros (2002), os "fardos” dessa dinâmica familiar.

Tal conjuntura permite dizer que não chegamos ao fim da família, mas à dissolução da família idealizada. Sendo assim, os indivíduos têm de construir sua identidade e seus comportamentos sem um modelo pronto de conduta.

Negreiros e Féres-Carneiro (2004) pontuam que novas modalidades familiares estão sendo construídas e ainda é cedo para avaliar os resultados. Há muitas crianças e 
adolescentes sendo criados em famílias até então consideradas marginais ou inconcebíveis, como casais homossexuais, famílias adotadas ou que lançaram mão da inseminação artificial e mães tardias que adiaram a maternidade por razões profissionais.

O que se pode dizer é que os grupos familiares atuais têm de arcar com um número grande de papéis possíveis a homens e mulheres e buscam realizar arranjos para lidar com tarefas e afetos presentes neste meio. Houve muitas transformações importantes no conceito de família, do masculino e do feminino, das condutas, obrigações e possibilidades assumidas pelos indivíduos dentro deste contexto tão múltiplo e complexo que é o atual. Para as autoras citadas acima:

É importante manter uma postura crítico-reflexiva e não preconceituosa sobre as novas configurações familiares, na medida em que as novas famílias estão abrindo mão de uma dimensão maniqueísta, que opõe masculino e feminino, o que sem dúvida pode contribuir para o estabelecimento de uma nova ótica e de uma nova ética das relações entre homens e mulheres no contexto sócio-familiar contemporâneo (NEGREIROS; FÉRES-CARNEIRO, 2004, p.45)

Portanto, torna-se relevante pesquisar como jovens solteiros avaliam as relações conjugais, a condição masculina no interior da unidade doméstica - e fora dela - e o significado que atribuem à constituição de uma família.

\subsection{Masculinidade e gênero}

O termo masculinidade deriva do vocábulo masculinus e foi introduzido apenas em meados do século XVIII, em uma época em que se propunha o estabelecimento de critérios mais claros de diferenciação sexual (OLIVEIRA, 2004).

Para o autor acima citado, a masculinidade pode ser definida provisoriamente como "um lugar simbólico/imaginário de sentido estruturante nos processos de subjetivação", que "se apresenta como uma significação social, um ideal culturalmente elaborado ou sistema relacional que aponta para uma ordem de comportamentos socialmente sancionados" (OLIVEIRA, 2004, p.13). Essa visão é compartilhada por Gomes (2008) que considera a masculinidade como um espaço simbólico que se presta 
a estruturar a identidade de ser homem, construindo atitudes, comportamentos e emoções a serem adotados.

Um dos conceitos utilizados sobre masculinidade atualmente é adotado por Connell (1995a, p.71):

\begin{abstract}
Masculinidade, até onde ela pode ser definida de maneira tão breve, é simultaneamente um lugar nas relações de gênero, as práticas através das quais homens e mulheres engajam aquele lugar de gênero e os efeitos dessas práticas na experiência corporal, na personalidade e na cultura.
\end{abstract}

Têm-se encontrado, atualmente, referências à diversidade dos modos de ser masculino na mídia escrita e falada e na literatura sobre o tema. (MEDRADO, 1997; OLIVEIRA; BILAC; MUSZKAT, 2000). Essa diversidade é resultado das mudanças socioculturais e político-econômicas que vêm ocorrendo nas três últimas décadas, em que o movimento feminista teve papel significativo. Na realidade atual vivenciada pelos homens, ainda há muitas dificuldades em colocar em prática valores de gênero incorporados recentemente e influenciados pelo ideal da universalidade de direitos. Tais dificuldades se mostram por meio das contradições e na tensão entre transformação e permanência (GARCIA, 2006).

Ao tratar de mudanças e permanências de valores, recorre-se às contribuições teóricas a respeito da relação entre estrutura e agência desenvolvidas por Bourdieu (1977) e Giddens (1991). Ambos sugerem que as ações dos indivíduos e a estrutura social estão intimamente ligadas e, se a estrutura social condiciona a ação dos indivíduos, ela também pode ser transformada por meio dessa ação. Giddens (1997) propõe que as transformações realizadas pelas instituições modernas se relacionam diretamente com a vida individual.

As masculinidades se configuram como uma construção social que se institui a partir das relações de gênero. A masculinidade hegemônica para certa cultura é edificada em relação a outras possibilidades de exercício da masculinidade e também em relação às mulheres. No caso da cultura ocidental e, mais especificamente, na cultura brasileira, a masculinidade hegemônica é representada pelo modelo de homem branco, de camadas médias, heterossexual, bem sucedido profissionalmente, capaz de gerar e manter uma família; um homem que demonstre segurança, proteção e confiança. Esse modelo corresponde ao que Bilac et al. (2000), denomina "homem de família". 
O conceito de identidade hegemônica (CONNELL, 1995a) se apresenta como uma configuração de gênero que busca legitimar o patriarcado, garantindo a posição dominante dos homens e a subordinação feminina. A hegemonia se dará de fato apenas se houver correspondência entre o padrão cultural e o poder institucional (individual e/ou coletivo). Quando há transformações nas condições do patriarcado, os alicerces para a dominação de uma masculinidade são gradualmente esfaceladas. Desse modo, a hegemonia é passível de mudanças.

Essa imagem hegemônica do homem não corresponde necessariamente às características dos homens mais poderosos de fato, mas o que sustenta o seu poder e o que muitos homens são incentivados a apoiar. Edificada em relação às outras masculinidades e às mulheres, a masculinidade hegemônica esconde e subordina outras formas de masculinidade, apesar de não as extinguir por completo (CONNELL, 1987).

Giffin (2005, p.53) assinala que a cumplicidade de todos com essa masculinidade que goza de uma hegemonia é explicada pelo fato de que é "a expressão cultural da sua dominação sobre as mulheres, que legitima e naturaliza práticas de subordinação". Nesse sentido, a autora acima ainda afirma que o conceito dessa masculinidade explicita como as transformações constantes nas formas de masculinidade auxiliam a reproduzir a dominação e a submissão.

Nos anos 1980, os primeiros especialistas dos men's studies, ou estudos do homem, concordaram com a idéia de que não há uma masculinidade única, um modelo masculino universal que seja válido para todas as épocas e culturas; a masculinidade se configuraria como uma ideologia que tende a justificar a dominação masculina, uma vez que suas facetas apenas se transformam para a manutenção do poder do homem sobre a mulher (KORIN, 2001).

A antropóloga Margareth Mead foi a pioneira a defender a idéia da multiplicidade masculina, demonstrando que nossa sociedade é um excelente laboratório de observação dessa diversidade: a masculinidade carrega consigo suas diferenças, não somente de acordo com a época e a cultura, mas também segundo a classe social, a raça e a idade do homem.

Já Beauvoir (1980) propunha que a mulher não nasce mulher, mas que se faz mulher. Dessa forma, o mesmo se aplicaria ao dito primeiro sexo: o homem não nasce homem. Ele se torna homem. Se a masculinidade pode ser ensinada e construída, ela pode também ser transformada, ou desconstruída, para ser construída novamente. 
Atualmente, para alguns autores, o homem não é mais considerado como "o Homem", isto é, como o modelo do que é humano, mas o indivíduo do gênero masculino é apenas um aspecto da humanidade. A masculinidade, por sua vez, é reconhecida como um conceito relacional, porque somente pode ser definida em relação à feminilidade. Os teóricos anglo-americanos, como Kimmel (1998), destacam a concepção de que masculinidade e feminilidade são construções relacionais: ainda que o macho e a fêmea possam ter características universais, não se pode compreender a construção social da masculinidade ou da feminilidade sem referência ao outro pólo relacional.

A introdução do caráter relacional do gênero promoveu uma revisão dos estudos centrados nas mulheres e apontou para a necessidade de pesquisas sobre as relações de gênero, já que a história das mulheres não pode ser enxergada de forma separada da história dos homens. Para Araújo (2005), o mundo das mulheres faz parte do mundo dos homens, não são esferas separadas. Conceber esses dois mundos como esferas separadas, segundo a autora citada, reforça o mito de que a experiência de um sexo tem muito pouco ou nada a ver com o outro sexo.

Ao tratar dos temas sexo e gênero, é fundamental entender estes dois conceitos para que se possam compreender determinados comportamentos humanos no que diz respeito à sexualidade. Gênero e sexo não são sinônimos, mas dimensões distintas das experiências humanas.

O sexo é definido pelas características anatômicas e pelo funcionamento do aparelho reprodutor que determinam o sexo ao qual pertence o indivíduo. Gênero é uma construção social que define o que significa ser de um sexo ou de outro na sociedade (HARDY; JIMÉNEZ, 2000; SCOTT, 1995;). Gênero compreende uma série de significados culturais atribuídos às diferenças biológicas. Estes significados variam temporalmente em uma cultura, entre uma cultura e outra, espacialmente, e longitudinalmente ao longo da vida de um mesmo indivíduo (KORIN, 2001).

Para Butler (1990, p.33), o gênero é “a estilização repetida do corpo, um conjunto de atos repetidos entre o enquadramento altamente regulatório que se congelou através do tempo para produzir a aparência de substância, de um tipo natural de ser".

De forma geral, gênero é a forma pela qual as capacidades reprodutivas e as diferenças sexuais dos corpos humanos são trazidas para a prática social e tornadas partes do processo histórico. 
A noção de gênero, diferentemente da concepção de sexo, mais do que se restringir à referência ao exercício da prática sexual, abrange atitudes, relações, comportamentos, valores, conceitos e preconceitos, que são social, histórica e politicamente construídos. Segundo Medrado (1996, p.3):

O conceito de gênero surge como uma tentativa de aglutinar interesses comuns e ampliar a compreensão das relações entre os sexos, apoiando-se na idéia de que existem machos e fêmeas na espécie humana, mas, principalmente, que a qualidade de ser homem e ser mulher é definida em termos de relação entre ambos e do contexto sócio-histórico mais amplo em que eles interagem.

Desse modo, ao se tratar de gênero, trabalha-se com práticas, símbolos, representações, normas e valores que dizem respeito à diferenciação sexual, com uma ocorrência histórica, que se fazem presentes na cultura e são compartilhados pelos indivíduos inseridos em certa sociedade. Segundo Scott (1995), a utilização do conceito de gênero ocorreu inicialmente para se referir à organização social entre os sexos; posteriormente, para enfatizar o caráter social das distinções fundadas sobre sexo e rejeitar o determinismo biológico implícito nos termos sexo ou diferença sexual. A autora citada propõe que o uso do termo gênero para designar relações sociais entre os sexos rejeita radicalmente explicações biológicas que encontram um denominador comum para diversas formas de subordinação feminina.

O termo gênero se configura, dessa forma, como uma maneira de indicar construções culturais sobre papéis adequados aos homens e às mulheres. Trata-se de uma forma de se referir às origens exclusivamente sociais das identidades subjetivas de homens e de mulheres. Gênero é, de acordo com essa definição, uma categoria social imposta sobre um corpo sexuado. Com a proliferação dos estudos sobre sexo e sexualidade, gênero tornou-se um termo bastante útil, uma vez que oferece um meio de distinguir a prática sexual dos papéis sexuais atribuídos às mulheres e aos homens.

Ampliando a análise, Scott (1995) considera que gênero é um elemento constitutivo das relações sociais alicerçadas nas diferenças percebidas entre os sexos e também um modo primordial de dar significado às relações de poder. Essas duas proposições estão intrinsecamente relacionadas, pois as mudanças na organização das relações sociais correspondem sempre a mudanças nas representações de poder; entretanto, a direção da mudança não segue necessariamente um único sentido. Embora gênero não seja o único campo no qual o poder se articula, ele parece ter constituído um 
meio persistente e recorrente de dar eficácia à significação do poder no ocidente, nas tradições judaico-cristãs e islâmicas.

Assim, a análise das relações sociais de gênero é importante para se compreender que as relações de poder entre homens e mulheres não têm um fundamento natural e imutável, mas que são socialmente construídas e, portanto, podem ser modificadas no processo histórico de construção das identidades de gênero.

Para Bourdieu (1995), a divisão do mundo, assentada sobre as diferenças biológicas que se referem à divisão sexual do trabalho, procriação e reprodução, opera como a mais fundada das ilusões coletivas. Estabelecidas como um conjunto objetivo de referências, as representações de gênero estruturam a percepção e a organização concreta e simbólica de toda a vida social.

$\mathrm{Na}$ medida em que essas referências estabelecem distribuições de poder, o gênero encontra-se relacionado com a concepção e a construção do poder. Entende-se, portanto, que gênero é uma categoria empírica e histórica e, assim sendo, pode ser usado como categoria analítica. Apreendido a partir da realidade empírica, gênero expressa as relações históricas e as formas de existência da realidade social entre homens e mulheres. (ARAÚJO, 2005).

Essa qualidade dinâmica da categoria gênero manifesta-se nas características psicológicas, nas posições sociais e econômicas, que culminam em ações e comportamentos específicos de homens e mulheres. Antes mesmo de a criança nascer, sua masculinidade ou feminilidade já começa a ser formada na imaginação dos futuros pais pelo desenho de um comportamento diferente para meninos e meninas (PASCHOALICK; LACERDA; CENTA, 2006).

O gênero também traz consigo novas possibilidades para se pensar a questão do homem e da mulher, articulando as relações entre sujeito e sociedade (SCOTT, 1989). Ao incluir o homem neste debate, observa-se a relevância do questionamento das posições sociais que caracterizam o modelo masculino em nossa cultura, percebendo o modo como os homens se vêem, como se representam e como constroem a própria identidade. 


\subsection{O "ser homem"}

O que é, afinal, ser homem? Para Nolasco (1997), meninos e meninas crescem acreditando que mulher e homem são o que são por natureza. No modelo masculino a ser seguido, a ênfase recai sobre a idéia de que o homem de verdade é reservado no que diz respeito a suas experiências pessoais ou, quando prático e superficial, é impulsionado à ação e a realização de atividades. Além disso, o homem de verdade está ligado ao heterossexual, provedor e pai de família (WELZER-IANG, 2001)

Segundo González Rey (2003, p.263), a identidade deve ser entendida como "um sistema de sentidos que se articula a partir das configurações subjetivas historicamente construída na história de um sujeito concreto e nas condições concretas dentro das quais ele atua neste momento".

A identidade, seja ela de sexo, etnia ou raça, é uma entidade abstrata e fundamental como ponto de referência; é também uma construção discursiva que transcende indivíduos e grupos restritos, inserindo-os em uma perspectiva totalizante dada em um determinado contexto histórico (COUTINHO, 2000). Para Ortiz (1985), a identidade não é algo estático, mas uma construção histórica, reunindo características fragmentadas em instâncias mais gerais, como nos exemplos da masculinidade e da feminilidade. Desse modo, traços esperados de homens e mulheres acabam por definir o que se chama "identidade" masculina e feminina.

A preocupação com a identidade não é algo novo (SANTOS, 1994). As discussões e reflexões têm apontado que o homem é a construção do próprio homem (ELIAS, 1994), em processo a ser realizado. Sendo assim, desconstrói-se uma visão essencialista, observada nas sociedades modernas, em que as identidades eram consideradas homogêneas e passa-se a adotar uma perspectiva mais condizente com a realidade atual, que abarca a flexibilidade, a heterogeneidade e a pluralidade.

Para Hall (2000), o sujeito que viveu possuindo uma identidade unificada e estável, sem modificações, está se tornando fragmentado, sendo constituído não de uma única, mas de várias identidades que, por vezes, mostram-se contraditórias e não resolvidas. As identidades tradicionais passam por um processo de declínio e o que atualmente é designado por crise da identidade é parte de um processo de transformações na sociedade moderna. A identidade emerge como problema quando se 
encontra em crise, quando algo fixo é vivenciado como algo sujeito a muitas transformações.

De modo geral, a noção de identidade tem uma dimensão pessoal e outra social. A identidade pessoal está relacionada aos atributos pessoais do sujeito, à sua subjetividade e constitui um processo de auto-identificação construído no decorrer da vivência de cada um em diferentes esferas da vida social. A identidade social inclui as características atribuídas a cada indivíduo, em função de sua inclusão em determinado universo social (GOFFMAN, 1978).

As identidades sociais podem, portanto, ser concebidas como contraditórias, fragmentadas, abertas e inacabadas, sujeitas a renegociações. Dessas renegociações, poderiam emergir novas identidades sociais, que se distanciam dos padrões adotados na cultura.

Conforme a integração do indivíduo em contextos sociais específicos, como os de classe social, ocupação, religião, etnia, o sujeito incorpora características desses universos (GOFFMAN, 1978). Tanto a identidade pessoal quanto a social são contrastantes, isto é, estabelecem semelhanças entre seus portadores e diferenças entre eles e outros sujeitos individualizados e entre eles e os componentes de outros grupos (OLIVEIRA, 1976).

Segundo Mucchielli (1986), a aquisição da identidade social, étnica, psicológica ou sexual é um processo extremamente complexo, que traz em seu bojo uma relação positiva de inclusão e uma relação negativa de exclusão. Assim sendo, identificamo-nos tanto através das semelhanças com algumas pessoas quanto pelas diferenças com outras.

Tal constatação demonstra não somente a relevância do reconhecimento social da diferença dos gêneros para que a criança tenha um claro sentimento de identidade, mas aponta também para o fato de que esta diferenciação continua a se desenvolver - e que, logo, pode ser modificada - por meio das diversas experiências vivenciadas.

Para Santos (1994), o primeiro nome moderno da identidade é a subjetividade, formado a partir do termo subjetivo, referindo-se a aquilo que pertence à consciência individual, assim como ao pensamento humano. Assim sendo, a subjetividade pode ser definida como o fundamento da identidade, pessoal e individual. Castoriadis (1999, p.35) busca articular as noções de sujeito e subjetividade:

O sujeito é essencialmente aquele que faz perguntas e que se questiona, seja no plano teórico ou no que chamamos prático. 
Chamarei subjetividade à capacidade de receber o sentido, de fazer algo com ele e de produzir sentido, dar sentido, fazer com que cada vez seja um sentido novo.

Para Ortner (2003, p. 376), a subjetividade é compreendida como "o conjunto de modos de percepção, afetos, pensamento, desejo, medo, e assim por diante, que animam os sujeitos atuantes" e é a base da agência, uma parte da compreensão de como os indivíduos agem no mundo. A agência é constituída enquanto desejos e intenções específicas imersas em sentimentos, pensamentos e significados culturalmente construídos.

Seidler (1991) analisa a construção do gênero masculino através da sua identificação com a razão. Os homens são forçados a serem independentes e autosuficientes para poderem competir no âmbito público, o que os leva a relegar necessidades afetivas em prol da razão. Assim sendo, pagam um alto preço ao assumirem essa identidade: a fragmentação de um ser dividido contra si mesmo.

Desde a concepção do bebê macho até a virilidade adulta, a construção da condição e da subjetividade masculinas é cheia de obstáculos. Os perigos se iniciam desde sua constituição biológica, e se estendem ao longo da existência física, psicológica e sociocultural dos homens. Ainda no útero materno, o embrião, e posteriormente o feto do sexo masculino, têm maiores dificuldades de sobrevivência, já que é maior o número de abortos de embriões e fetos machos, o que talvez indique a sua maior fragilidade em relação aos embriões do sexo feminino (BADINTER, 1993).

Tal ameaça de fragilidade se mantém no primeiro ano de vida, pois morrem mais crianças do sexo masculino nesta faixa etária. Outro dado é que se sabe que a mortalidade masculina é significativamente superior à das mulheres, ao longo de toda a vida (BORIS, 2000).

Um dos principais motivos da maior vulnerabilidade física masculina, segundo Badinter (1993) é o fato de que ela, provavelmente, é oriunda da também maior fragilidade psíquica dos homens. Desse modo, o menino, gerado e nascido no ventre de uma fêmea, deve diferenciar-se da mulher ao longo da maior parte de sua vida - ao contrário da menina - uma vez que só pode ter garantida a sua existência de macho ao opor-se a sua mãe, a sua própria feminilidade original e a sua condição de dependência e passividade.

Assim, "por três vezes, para afirmar uma identidade masculina, deve convencerse e convencer os outros de que não é uma mulher, não é um bebê e não é um 
homossexual" (BADINTER, 1993, p. 35), afirmando sempre que é um homem, que é um adulto e que é um heterossexual. Ser homem representa a oposição de não ser "veado", "bicha", homossexual, "maricas", "corno", que são figuras portadoras de representações de feminilidade, fraqueza e subordinação (PARKER, 1991).

Já Gikovate (2000) pontua que uma das particularidades da cultura brasileira é permitir uma maior liberdade para o exibicionismo físico feminino do que para o masculino. No caso de meninos/homens, há um pavor de que o prazer de chamar a atenção fisicamente acabe culminando na homossexualidade. Desse modo, o padrão de masculinidade se constrói não em oposição à feminilidade, mas com o objetivo de impedir a homossexualidade. A masculinidade seria, então, edificada em oposição à homossexualidade, ao passo que a feminilidade seria construída em oposição à masculinidade.

Essa situação é agravada devido ao fato de que a masculinidade do menino é menos estável e menos precoce do que a feminilidade da menina. De fato, a masculinidade é social e culturalmente construída, secundária e frágil, sendo desenvolvida a partir da feminilidade original, pois é significativamente mais importante para os homens do que é a feminilidade para as mulheres (HACKER, 1957). São comuns situações cotidianas nas quais os homens se esforçam para demonstrar, provar e reafirmar sua virilidade, o que não é tão comum entre as mulheres no tocante à sua própria feminilidade.

A construção social do homem se apresenta, fundamentalmente, homossocial: implica numa constante auto-aprovação e aprovação dos outros homens (KORIN, 1996; GRIMBERG, 1999). Embora haja uma variação nas masculinidades no que toca a diferenças internas de classe social, idade, raça, etnia ou orientação sexual, de forma geral significam "Não ser como as mulheres" (KIMMEL, 1997). Como há a dependência da aprovação dos outros homens, a emoção mais pronunciada é o medo, o que coloca a homofobia como principio organizador da definição de virilidade. Desse modo, o medo leva à vergonha, ao silêncio e à violenta afirmação da masculinidade.

O paradigma de virilidade que reinava de forma inconteste até recentemente resultava de um processo socializador opressivo por meio do qual o menino aprendia desde cedo a relegar suas emoções e a desvalorizar seus desejos mais profundos. Cresciam estimulados a serem livres e independentes, a supervalorizar suas conquistas, a contar vantagens e a desenvolver a competitividade como um dos traços principais para se estabelecer quando adulto. A preocupação com o seu desempenho era constante 
ao longo da vida e havia um estímulo para atividades e jogos que tinham duas possibilidades: ganhar ou perder. O perdedor era humilhado e ridicularizado, o vencedor, festejado e elogiado (WANG; JABLONSKI; MAGALHÃES, 2006).

Para os autores acima citados, o controle emocional e corporal levado ao extremo ocasionava um embotamento afetivo que limitava as possibilidades de usufruir o prazer masculino somente ao órgão sexual e, em decorrência, a sexualidade masculina também se empobrecia - já que o pênis tinha de arcar com toda a responsabilidade pela fruição da satisfação sexual.

Esses fatos possibilitam entrever as formas como o homem está inserido nesta sociedade de tradição patriarcal, ou seja, a partir de valores hegemônicos e estruturas de poder que o diferenciam da mulher e que, simultaneamente, moldam seu comportamento.

Segundo Medrado (1998), são poucos os homens que conseguem seguir a contento o modelo de comportamento esperado e a ele atribuído pela sociedade em que vive. O estereótipo masculino considerado normal nas sociedades contemporâneas ocidentais está relacionado à idéia de um sujeito fisicamente forte, competitivo, produtivo, ativo em seu trabalho, com capacidade de sustentar sua família e possuir várias mulheres. Convém observar que esse modelo aproxima-se do "homem de família" e que se refere fundamentalmente à posição de homem casado, responsável por sua família.

A adequação dos homens a este modelo de homem ideal não é atingível por praticamente nenhum homem, mas de forma análoga, exerce um efeito de controle que exclui da vivência masculina todo um campo afetivo que é concebido como sendo feminino (MEDRADO, 1998). É nesse sentido que Nolasco (1993) menciona a negação da sensibilidade masculina, comum na educação dos homens, e a atribui ao fato de que a dinâmica subjetiva sempre foi considerada propriedade das mulheres, o que levaria muitos homens, ainda hoje, a adotar para si mesmos parâmetros de comportamento pautados nessa negativa ou numa pretensa objetividade masculina. Sobre a apregoada objetividade masculina, Campolim e Lima (1998, p. 27) alertam que os homens apenas parecem ser mais

[...] pragmáticos. Mas, na verdade, não o são. Essa aparência se mantém à custa da negação de certos elementos da experiência, tais como o acaso, os sentimentos, as oscilações emocionais, que a atitude 
masculina põe de lado ou nega para poder manter o sentimento de que as coisas estão transcorrendo dentro de uma aparente racionalidade.

Entre as várias características da construção da condição masculina, Nolasco (1993) destaca as dificuldades profissionais vivenciadas num contexto social que desqualifica a manifestação da individualidade, da singularidade e da subjetividade dos homens, a ausência impactante do pai em suas vidas, bem como sua inserção social através de atitudes autoritárias, competitivas e violentas, que se opõem a qualquer manifestação afetiva em seu cotidiano.

A esse pensamento hegemônico de masculinidade, tem-se atribuído a gênese de muitos agravos à saúde e a permanência de relações assimétricas entre homens e mulheres. Tal hegemonia, aceita e acatada por homens e mulheres, cada vez mais é geradora de tensões, mal estar, conflitos para os homens e de dificuldades de relacionamento entre eles e as mulheres (PASCHOALICK; LACERDA; CENTA, 2006).

Estudos demonstram que os homens, de forma geral, sofrem mais de condições crônicas e severas de saúde do que as mulheres e também morrem mais do que elas pelas principais causas de morte. Do mesmo modo, observa-se que a presença de homens nos serviços de atenção primária à saúde é menor do que a feminina (GOMES, NASCIMENTO ; ARAÚJO, 2007). Nesse sentido, também se faz necessária uma reflexão acerca da própria masculinidade para um melhor entendimento dos comprometimentos da saúde do homem.

Para Badinter (1993), o refúgio no álcool e nas drogas e também a impotência são produtos da fragilidade masculina diante de novos imperativos sociais, que impõem aos homens novas demandas e obrigações sexuais. A manutenção do ideal viril tem um preço muito alto para os homens, que se esforçam enormemente para se encaixarem em um modelo de masculinidade que supervaloriza o tamanho do pênis e o desempenho sexual, o que pode causar angústia, depressão, crises de stress e ansiedade, dificuldades afetivas e comportamentos destrutivos.

Segundo Gomes e Nascimento (2006, p.909):

A construção da masculinidade com marcas identitárias - como a adoção do status quase que exclusivo de ser ativo, a crença de que deve expressar invencibilidade, a associação do masculino à necessidade de expor-se ao risco, a naturalização do descontrole 
sexual e a redução do exercício da sexualidade à penetração - pode influenciar a não adoção de medidas de proteção contra doenças.

Os homens que não conseguem atender ou satisfazer todos os atributos dessa representação de masculinidade sofrem terrivelmente, tanto no plano social quanto no psicológico, para demonstrar sua macheza. Ao não demonstrarem os atributos masculinos esperados, poderiam ser vistos como mulheres ou homossexuais, condição que deve ser veementemente repudiada (KORIN, 2001).

Assim sendo, garantir a posição de poder tradicionalmente atribuída ao sexo masculino é tarefa árdua para os homens. Sentir-se fraco, ficar doente, ser traído pela mulher, perder o emprego, ser estéril ou impotente, tornam-se não são apenas condições e circunstâncias desagradáveis, mas indícios ameaçadores do referencial de virilidade. É justamente tentando ser forte que o homem se torna vulnerável e passa a sofrer consequências do papel que ele se propõe a representar na sociedade (MUSZKAT, 1998).

A esse respeito, Gikovate argumenta (2000, pp.13-14):

Uns mais e outros menos, todos os rapazes acabam por constatar que a condição masculina não é tão vantajosa assim. Imaginam como se sentem as moças - as mais atraentes, é claro - que estão sempre sendo assediadas [...] Não há como escapar da conclusão: as mulheres têm uma arma a mais do ponto de vista sexual.

O sofrimento experimentado na interioridade, na esfera psicológica masculina, acaba sendo fruto da subordinação dos homens ao pensamento hegemônico de masculinidade. A concepção de "ser homem" oferece, por um lado, poderes e privilégios; entretanto, por outro lado, é fonte de dor e de alienação, pela maneira com que os homens interiorizam e reforçam tal representação. A alienação masculina também é uma alienação de sentimentos, afetos e de relacionamentos humanos de cuidado (LYRA, 1998).

Neste sentido, é relevante problematizar aspectos da vivência masculina dentro da pesquisa em questão, no que se refere às condições e formas de expressão de afetos e emoções dentro de seus relacionamentos. 


\subsection{A construção da subjetividade masculina e a crise da masculinidade}

Analisando as relações sociais de gênero e, particularmente, a questão do poder masculino, Bourdieu (1998) discute a necessidade de esclarecer a dominação masculina, mostrando como as mulheres podem contribuir para sua própria dominação. Segundo o autor, somente o reconhecimento de que as próprias mulheres são construídas socialmente e que reproduzem o poder masculino pode propiciar uma verdadeira revolução simbólica e a consequente transformação das relações sociais de gênero.

As diferenças sexuais estão inseridas e submersas num sistema de oposições, em que a oposição masculino/feminino carrega consigo uma necessidade objetiva e subjetiva (BOURDIEU, 1998). Apesar da divisão dos sexos estar inscrita na ordem social das coisas - sendo, portanto, objetiva - essas divisões objetivas estão inscritas nos corpos, por meio de disposições, e se tornam princípios subjetivos de visão através das quais os indivíduos enxergam e edificam o mundo como realidade significativa.

Pode-se observar que traços da dominação masculina ainda estão presentes em vários locais do mundo, inclusive na atual sociedade brasileira. Os homens ainda dominam a esfera pública, ainda têm salários mais altos do que as mulheres, mas já não podem ser considerados como únicos provedores; a heterossexualidade ainda é predominante, mas a homossexualidade vem se tornando cada vez mais um estilo de vida aceitável (WERNECK, 1987).

Entretanto, pode-se perguntar o que vem acontecendo com a subjetividade e a condição masculinas quando sistematicamente as mulheres vêm avançando em diversos espaços sociais, conquistando novas posições no mercado de trabalho e na família e, consequentemente, provocam transformações nas relações sociais de gênero.

Diante de tantas mudanças, o homem do final do século XX não sabe mais como se definir com clareza, ao menos com a mesma segurança de que dispunha. Atualmente, a masculinidade vem sofrendo múltiplas transformações socioculturais e assumindo uma diversidade subjetiva tamanha que se tornou também difícil sua definição por parte daqueles que se dedicam aos estudos da condição e da subjetividade masculinas.

Nos últimos anos, o debate a respeito da identidade masculina tem apontado para uma crise da masculinidade do homem contemporâneo, que estaria sendo colocado em "xeque" porque estaria perdendo a noção de sua própria identidade e procurando uma 
melhor definição de si mesmo. A discussão em torno da diferença entre os sexos seria uma das características dessa crise da masculinidade a que se refere (SILVA, 2000).

Especialmente a partir dos anos 1960, embora tênue e sutil, começou a se desenvolver uma crescente postura entre alguns homens que, se já não adotam a conduta e a linguagem machistas de tempos anteriores, ainda não encontraram uma atitude alternativa diante das diversas mudanças socioculturais que vêm se desenvolvendo nos últimos anos, particularmente quanto às conquistas das mulheres. É nesse sentido que, no cenário das investigações sobre gênero, surgem cada vez mais estudos específicos sobre o homem e a masculinidade.

Desde a década de 1970, a questão masculina tem sido objeto de muitos estudos, em diferentes países, como Estados Unidos, Canadá, França, Brasil e Peru (BADINTER, 1993; BLY, 1991; CARRIGAN; CONNELL; LEE, 1985; FULLER, 1997; NOLASCO, 1993). Com o movimento feminista e o significativo volume de estudos sobre as mulheres, alem da participação do movimento e dos estudos gays, a hegemonia da ideologia que pregava a superioridade masculina se viu sob forte contestação. Nas universidades, e em espaços da classe média, homens se dedicavam à reflexão a respeito de suas próprias vivências no patriarcado e reconheceram os hábitos masculinos de dominação e desvalorização como seus. Segundo os participantes, "havia sentimentos de muita culpa; como no feminismo, havia discordância e conflito" (GIFFIN, 2005, p. 49).

O final da década de 1960 e início dos anos 1970 são períodos importantes nas mudanças dos papéis femininos e masculinos na sociedade brasileira. O Brasil começou a sentir os efeitos do movimento feminista, que estava sendo constituído nos Estados Unidos e na Europa, através dos meios de comunicação como revistas, jornais, cinemas e teatros, que passaram a oferecer espaço para as propostas e reivindicações femininas. Para Goldenberg (2001), o denominador comum das lutas feministas foi o questionamento da divisão tradicional dos papéis sociais, com a negação da visão da mulher como o "sexo frágil" ou o "segundo sexo", cujo expoente é o papel de "esposamãe".

A expansão da psicanálise também auxiliou sobremaneira a rejeição de práticas que eram concebidas como autoritárias e repressivas, assim como o questionamento da obrigatoriedade de se vivenciar a sexualidade dentro do casamento legítimo. As mulheres reivindicaram igualdade na esfera pública e privada e a negação de valores morais sexuais diferentes para homens e mulheres. Viviam também o dilema entre 
continuar sendo a "esposa-mãe", voltada ao mundo doméstico e aos filhos, ou ser uma mulher inserida no mercado de trabalho, independente, que busca o controle de sua própria vida e sua satisfação sexual - modelo este defendido pelas lutas feministas e pela psicanálise (GOLDENBERG, 2001)

À medida que o movimento feminista levantava uma discussão sobre os novos papéis sociais estabelecidos, tanto para homens quanto para mulheres, e essa discussão passou a se pautar sob a perspectiva feminina, ficou mais definida e solidificada a representação da mulher enquanto um "ser social". As pesquisas passaram a tematizar o estudo do homem, propondo também uma nova forma de se ver o masculino. Como reflexo desse cenário, os homens passaram também a reivindicar uma nova qualidade no espaço social, reconstruindo e revisando sua própria identidade (SILVA, 2000).

A literatura da década de 1970 começa a tratar das contradições entre a identidade masculina hegemônica e as reais condições de vida dos homens, o que levantava a discussão a respeito das desvantagens de ser homem.

Diversos teóricos das ciências humanas, principalmente dos Estados Unidos, inauguraram os questionamentos sobre os estereótipos masculinos, entendendo-os como fonte de alienação para os próprios homens, como fator gerador de desentendimento com as mulheres e como inibidor do exercício harmonioso das tarefas relativas à paternidade.

Essa década produziu os primeiros trabalhos científicos sobre masculinidade, que tinham o tom da paixão que acompanhava suas denúncias. Os anos 1980 constituíram um período de incerteza, carregado de angústias e de dúvidas, pois mais do que nunca o homem passou a ser compreendido como um problema a ser resolvido, não mais como uma questão dada e preconcebida (Boris, 2000).

Tendo por objetivo primordial repensar o masculino e compreender os processos de mudança por que passam os homens, tais estudos adotaram em suas análises a perspectiva social e/ou relacional de gênero:

Longe de ser pensada como absoluta, a masculinidade, atributo do homem, é relativa e reativa. Tanto que, quando a feminilidade muda em geral, quando as mulheres querem redefinir sua identidade - a masculinidade se desestabiliza (BADINTER, 1993, p.11) 
Repensar a questão masculina pressupõe a revisão de modelos de comportamentos, teorias e discursos que, ao longo da história, têm sido usados para explicar a masculinidade (NOLASCO, 1995; OLIVEIRA, 1998).

Com a necessidade de trabalhar para complementar a renda familiar e/ou realização pessoal, a mulher se depara com novas questões, como o controle da reprodução biológica e a necessidade de dividir tarefas e responsabilidades na esfera doméstica. Como consequência, todas essas questões tiveram implicações na vida dos homens. O que não quer dizer, segundo Nolasco (1993), que a transformação vivida pelos homens seja apenas decorrência do movimento das mulheres, uma vez que o movimento dos homens tem características próprias.

A mudança das mulheres e a mudança dos homens expressam a crise do individualismo vivenciada como crise do sentimento de identidade. Ainda para Nolasco (1993), a crise de identidade dos homens se inicia com a crise do mundo do trabalho e da família e não com o feminismo.

Os vários estudos sobre a condição masculina vêm questionando e reavaliando a posição social masculina nas guerras, nas políticas de dominação e nos problemas trabalhistas, raciais, sexuais e propriamente de gênero, a partir da constatação de que muitos homens conquistaram sua autonomia de vida ao preço de um desenvolvimento desumanizado, esquecidos de seus afetos e envoltos numa enorme solidão.

Neste sentido, Goldberg (1994) aponta que a existência masculina é pautada numa rotina uniforme e contínua no que diz respeito a seus afetos e ao trabalho, tendo na representação da ausência paterna seu expoente máximo.

No presente, observa-se em diversos homens uma atitude contrária às posturas distantes, inexpressivas e padronizadas no contato com os filhos, sinalizando suas angústias e ansiedades frente à paternidade, diferenciando-se da representação divina da figura do pai no ocidente, caracteristicamente alicerçada em uma moral repressiva e distanciadora, e tentando construir uma nova relação com os filhos, fundada na cumplicidade, no prazer e na gratidão.

A partir da década de 1980 nos Estados Unidos e dos últimos anos da década de 1990, no Brasil, nasceu uma discussão a respeito dessa chamada "crise da masculinidade". Mas de que crise se fala? Gomes (2003) aponta que o masculino não está em crise, já que, enquanto gênero em si, vive em crise permanente. Desse modo, a masculinidade não é algo que já vem pronto e dado, mas é algo que deve ser 
conquistado. $\mathrm{O}$ feminismo e suas conquistas não causaram a crise masculina, mas a tornaram mais visível.

Para Goldenberg (2000), talvez o estereótipo de machão viril esteja realmente passando por uma crise, mas é possível que ele sobreviva. Entretanto, terá de conviver com outras formas de ser homem. O que já não sobrevive mais é um modelo hegemônico masculino com base na agressividade, virilidade e poder, ainda que homens e mulheres avalizem esse ideal.

Cresceu de forma significativa o número de pesquisas e reportagens tratando de novos comportamentos e concepções adotadas pelos homens. A publicidade, os meios de comunicação e a literatura também contribuíram para o incentivo à aquisição e à adoção de novos produtos e serviços e, consequentemente, de novos hábitos masculinos.

Um tipo de homem cada vez mais encontrado na publicidade é o denominado masculino "equilibrado" (GARBOGGINI, 2005), um homem sensível e participante, representado desde a segunda metade da década de 1990. O homem em equilíbrio, ou nas palavras de Badinter (1996), o "homem reconciliado", mantém sua masculinidade e convive bem com sua sensibilidade, sem maiores problemas em exercer atividades consideradas femininas.

De acordo com Wilm (2002), o homem “sensível” está retratado em publicações destinadas ao público feminino, como as revistas Cláudia, Marie Claire e Elle, ao passo que o homem "conquistador" está mais presente em revistas masculinas, como Exame, Playboy e VIP. Interessante observar que o modelo de homem apresentado está relacionado ao público alvo que os anúncios pretendem alcançar. Nas revistas femininas, os homens aparecem como o parceiro dedicado, preocupado com o prazer da companheira, o pai atencioso. Já na revistas masculinas, é apresentada uma imagem de superioridade, invariavelmente.

Emerge também nesse contexto a figura do metrossexual, termo utilizado pela mídia internacional e formado pela junção das palavras metropolitano e heterossexual, indicando um homem urbano preocupado demasiadamente com sua aparência e que gasta muito com cosméticos, acessórios e roupas de marca.

No Brasil, desde o final da década de 1980, tem-se questionado o comportamento masculino, o que de certo modo tem contribuído para que os homens possam modificar-se ou, ao menos, cria condições propiciando uma "autorização social" (NOLASCO, 1988, p. 17) para que realizem tarefas até então consideradas das 
mulheres. Tal panorama despertou certo reconhecimento e até mesmo uma valorização de situações cotidianas e de sensações que não lhes eram permitidas, sem o risco de serem considerados "maricas", como ocorria anteriormente. Neste período, conforme informa Nolasco (1988, p. 18):

[...] um pequeno número de homens brasileiros, individualmente, começa a repensar como constroem seus vínculos afetivos e de trabalho fora do crivo do estereótipo social para eles definido. Estes indivíduos buscam encontrar caminhos próprios para suas vidas, ampliando-os para além da redução a que ficaram submetidas pelo patriarcado que separa a "vida de um homem" da "vida de macho". Neste sentido, procuram compreender as razões que os fizeram adotar um padrão de comportamento a que obedecem cegamente. [...] Os homens interessados em repensar sua forma de adesão à vida começam a avaliar o "preço que pagam" para manter esta senhorilidade, e se perguntam se vale a pena sustentá-la.

No final do século XX e início de século XXI, ainda se notam tensões na construção da identidade sexual masculina. A pesquisa de Goldenberg (1991) reflete essas tensões frente a padrões socialmente construídos. Há a presença de alguns marcos para a afirmação da identidade masculina: a iniciação sexual com prostitutas; a referência constante a certo padrão de comportamento sexual masculino; o desejo de corresponder às expectativas sociais, especialmente dos amigos e das mulheres e a negação veemente da homossexualidade.

Nesse mesmo sentido, tratando das fronteiras da masculinidade na classe média, Tolson (1983), alerta que o papel masculino imposto ao homem é uma imagem de machismo e de virilidade, muitas vezes tão mutiladora para o homem como a imagem de feminilidade para a mulher. Dessa forma, a possibilidade de um movimento de libertação dos homens está diretamente relacionada a uma tomada de consciência por parte deles das limitações que lhes são impostas pela própria sociedade sexista.

Ao realizarem essa trajetória reflexiva, os homens estão se tornando mais conscientes dos conflitos impostos pelo machismo e descobrindo a possibilidade de, livres dos estereótipos construídos, reconhecerem suas reais necessidades afetivas e buscar meios de satisfazê-las sem se sentirem menos "machos" por isso. Abre-se, desse modo, a possibilidade da descoberta do prazer de amar e de se relacionar de outro modo, em que a abertura para a intimidade, para a troca afetiva e para o contato com os sentimentos pode tornar-se uma experiência significativa (NOLASCO, 1993). 
Atualmente, ao menos nas sociedades ocidentais, homens e mulheres estão se distanciando dos modelos estereotipados de gênero e lançando mão de novas formas de subjetividade, livres do imperativo das divisões traçadas pelas representações sociais até então vigentes. A idéia de que existe um modelo masculino ou feminino universal não se sustenta mais.

Amparados pela pluralidade e pela singularidade, nascem diferentes formas de ser da masculinidade e da feminilidade que convivem, de forma já não tão conflituosa, com os modelos hegemônicos de gênero ainda existentes. Nesse cenário, abre-se a possibilidade concreta de construir relações de gênero mais democráticas, nas quais o direito à igualdade e o respeito à diferença são imprescindíveis. Para Araújo (1999), esse continua sendo o ideal de relacionamento perseguido no casamento e na família desde a modernidade.

Dentro dessa perspectiva de tantas transformações, em que novos modelos masculinos estão sendo construídos, novas modalidades de relacionamento também estão sendo estabelecidas. Torna-se necessário e extremamente importante o questionamento a respeito de como o homem atual se enxerga, se descreve e se compreende inserido em uma realidade tão instável e passível de mudanças. Cabem também indagações sobre a maneira como ele compreende seus relacionamentos, que concepções e visões de mundo estão alicerçando a constituição de seus vínculos afetivos, as posições e papéis assumidos e negados por ele; suas opiniões acerca da relação com pais, mães, irmãos, amigos, amigas, namoradas. Suas expectativas no tocante à constituição de uma família. E, de forma especial, sobre o casamento.

\subsection{O casamento}

O casamento contemporâneo se insere como uma relação significativa muito intensa na vida dos sujeitos, já que pode incluir intimidade e envolvimento afetivo muito intenso. Para Féres-Carneiro (2005), o casamento cria determinada ordem que possibilita que a vida seja experimentada com mais sentido e essa atribuição do casamento como forma de construção da identidade o coloca como uma das relações mais significativas para os indivíduos contemporâneos. 
No caso do casamento, para Féres-Carneiro (1998, p.381), o fascínio e os percalços de ser casal residem no fato de que essa modalidade de relação encerra

[...] ao mesmo tempo, na sua dinâmica, duas individualidades e uma conjugalidade, ou seja, de o casal conter dois sujeitos, dois desejos, duas inserções no mundo, duas percepções do mundo, duas histórias de vida, dois projetos de vida, duas identidades individuais que, na relação amorosa, convivem com uma conjugalidade, um desejo conjunto, uma história de vida conjugal, um projeto de vida de casal, uma identidade conjugal.

Atualmente tem-se problematizado a questão do casamento de forma a compreender mais profundamente como ocorre essa forma de relacionamento, tamanha a complexidade que assumiu dentro da sociedade. Das uniões legais e religiosas, que eram atributo quase que imprescindível para a construção familiar nas últimas décadas, hoje se assiste a uma diversidade ampla nos relacionamentos conjugais.

Para Féres-Carneiro (1998), o casamento é uma forma de relação que protege o indivíduo de sua anomia. No mundo adulto, é fundamental o estabelecimento de vínculos significativos e o casamento constitui uma relação validada nesse sentido. $\mathrm{O}$ casamento ganha um caráter dramático, já que os mundos de dois indivíduos até então estranhos e desconhecidos um ao outro se encontram e se ressignificam por meio do vínculo. Desse modo, o casal constrói o presente e reconstrói o passado, integrando as memórias de dois passados individuais.

Uma modalidade de relação conjugal, proposta por Salem (1989, p.27), é denominada de "casal igualitário" e se assenta sobre a percepção da parceria como constituída de duas unidades fundadas mais em ligações subjetivas do que em regras sociais. Esse traço se reflete na crença de que o laço conjugal é concebido como

[...] suficientemente forte e auto-referido a ponto de isolar a parceria no campo das relações familiares - o que necessariamente, remete para a pressuposição de que ela deve estar dotada de uma identidade interna mais forte do que aquela que vincula cada um de seus membros aos respectivos núcleos de origem.

O casal, para a autora citada acima, é inteligível em seus próprios termos e independente do funcionamento tanto da unidade doméstica quanto da procriação. A ligação marital, com exceção da ligação pais-filhos, é enxergada como mais fundamental e próxima do que qualquer outra. Há um sentido de completude atribuído a essa união, expresso por uma busca incessante por esse ideal, o que talvez sugira a 
vulnerabilidade da ligação, quando o casal se torna uma unidade sobrecarregada de desejos, expectativas e frustrações e implode.

Nesse sentido, torna-se essencial a reflexão sobre o próprio relacionamento - o famoso "discutir a relação" - em que os parceiros se vêem em permanente estado de transformações.

Féres-Carneiro (1998) discute os efeitos do ideal do casamento contemporâneo, em que se deseja o outro por inteiro e se pretende penetrar na intimidade do parceiro por completo. O outro se torna um reservatório inesgotável de conteúdos latentes e a entrega total pode trazer consigo uma sensação de esvaziamento. Há uma idealização do parceiro e uma superexigência consigo mesmo, o que pode levar à ocorrência de tensões e à posterior separação do casal.

Estudos a respeito do casamento e separação no Brasil assinalam uma crescente taxa de divórcios e uma significativa diminuição dos casamentos formais, como já exposto anteriormente. Além de se casarem cada vez menos, os brasileiros estão se casando cada vez mais tarde. A idade média dos homens ao se casarem aumentou de 26,9 anos em 1990, para 31,6 anos em 2002 e das mulheres, de 23,5 anos para 26,3 anos no mesmo período avaliado (ANUÁRIO ESTATÍSTICO, 2004).

O aumento do número de divórcios na sociedade contemporânea parece indicar, em um primeiro momento, que o casamento acaba não sendo o lócus da auto-realização social e a base dos relacionamentos na esfera privada. Entretanto, para Féres-Carneiro (1998), é justamente porque o casamento é tão importante que os indivíduos não suportam que ele não atenda a suas expectativas. É essa dificuldade que o divórcio reflete e é bem comum que divorciados voltem a se casar.

Em sua obra Até que a vida nos separe, Jablonski (1991) formula o conceito de "fam-ilha”, uma versão contemporânea da família tradicional, uma ilha comandada pela lógica individualista, com a presença de desejos, vontades e demandas contraditórias. A vida conjugal é definida como "quase que impossível”, dados os paradoxos de nosso tempo: como conciliar monogamia, permissividade, fidelidade, liberdade, individualidade, vida familiar e social?

Esse questionamento traz à baila a reflexão de como se dão as relações dentro da família e como os meios de comunicação também contribuem para o estabelecimento de "ilhas" ou microcosmos no ambiente familiar.

Uma pergunta que surge nesse momento é se o avanço dos meios virtuais de comunicação diminuiu a distância no contato entre as pessoas, mas também aumentou a 
solidão e o isolamento do indivíduo, que ainda persistem. Há quem diga que o homem nunca esteve tão só na história como está agora. O tempo atual é associado a um saudosismo e à perda de algo que não se sabe o quê (TEIXEIRA, 2001).

Sobre esse aspecto Zeldin (1994) assinala que as pessoas viviam de modo confortável em uma família ou tribo e nem sequer sabiam o que era solidão, não se enxergando como indivíduos separados. Depois de pouco tempo, essa unidade foi desfeita e há uma epidemia de solidão convivendo lado a lado com a prosperidade e quanto maior o êxito, maior a probabilidade de sofrer desse mal, que o dinheiro não consegue resolver. Atualmente, a vivência de uma relação que não se desenvolve tornou-se ainda muito mais preocupante e a sede por novas experiências e diversos relacionamentos é maior do que nunca (ZELDIN,1994).

Nota-se, porém, que é uma relação mais integrada do ponto de vista reflexivo, embasada em questionamento persistente e contínuo, para o qual fazem suas contribuições jornais, revistas, programas de televisão, sites da Internet, entre outros.

Essa relação é permeada diretamente por um compromisso entre os parceiros, não é uma co-dependência, mas cada indivíduo deve estar inserido no relacionamento de forma segura do seu próprio valor, ainda que o vínculo esteja sujeito a tensões que abrem a possibilidade do seu término.

Deste modo, nota-se o que Giddens (1995) denomina de relacionamento puro, que se pauta na manutenção de um compromisso na medida em que o relacionamento proporcione satisfação às partes envolvidas e que desvincula amor e sexualidade, abrindo espaço para outras expressões de sexualidade, além da heterossexualidade, e propiciando uma reformulação na identidade feminina através da queda gradual da concepção de casamento vigente até então.

Com efeito, ocorre a imposição de uma reformulação no modo como se compõe a identidade masculina. O campo emocional permanece distante e historicamente inacessível ao homem em função também do papel que este assumiu na sociedade, de busca de status entre outros homens através de recompensas materiais e associado a rituais de solidariedade masculina.

Diferentemente da mulher, que durante muito tempo construiu sua autoidentidade através do casamento e dos relacionamentos, o homem construía sua autoimagem a partir do trabalho, sem uma compreensão reflexiva do "eu".

Como implicação do relacionamento puro, surge outra forma de amor, chamada amor confluente, que se contrapõe ao amor romântico pelo fato de que, ao contrário 
deste, o amor confluente não se sustenta na complementaridade inter-gêneros onde cada qual das partes envolvidas, incompletas se consideradas em separado, se unem para formar uma totalidade sustentada no par idealizado. $\mathrm{O}$ amor confluente presume igualdade na doação e no relacionamento emocional. A aceitação por parte de cada um dos parceiros é o que mantém esse tipo de relacionamento, cada um obtém da relação benefício suficiente que justifique sua continuidade (GIDDENS, 1995).

Tal igualdade de investimento emocional para a manutenção do relacionamento afeta os valores das famílias, como aponta Heilborn (2004), ao tratar das famílias de camadas médias, pois os valores que interferem no comportamento e na relação entre os indivíduos estão alicerçados sobre a liberdade e singularidade individuais, o que propiciou a emergência de uma recusa da distinção entre os gêneros e a explicitação da homossexualidade.

Desse modo, o casal contemporâneo tem de se haver com um paradoxo: de um lado, os ideais individualistas impulsionam o sujeito à autonomia, destacando que o casal deve sustentar o desenvolvimento de cada um dos cônjuges; por outro lado, emerge a necessidade de se viver a conjugalidade, seus planos e desejos (FÉRESCARNEIRO, 1998).

Segundo Béjin (1987), a tensão e as exigências dos cônjuges impossibilitam a viabilidade e a duração dos relacionamentos atuais, já que desempenhar diferentes papéis, como o de amante, esposo, amigo, irmão, confidente das pessoas com quem se convive acaba se configurando como um fardo pesado.

Para Augé (2005), a principal característica dos tempos atuais não é o fim da modernidade, mas o excesso, a hipertrofia e a deformação do tempo, do espaço e do eu. Os indivíduos não se enxergam como pertencentes a grandes coletivos sociais, mas a identidades particulares. $\mathrm{Na}$ ausência de referências culturais que legitimem a experiência com o outro, enquanto diferente e desejável, o eu acaba por investir em si mesmo como objeto de amor e de sustentação de sua identidade.

Uma transformação da perspectiva subjetiva do homem atual é a mudança da primazia do sentimento/pensamento para a sensação/corporeidade (COSTA, 1998), em que as identidades se sustentam mais pela imagem do que pela reflexão, mais pelo consumo do que pelo cultivo.

Em um mundo em que as pessoas estão voltadas a si mesmas, encantadas consigo mesmas, o amor se torna um sentimento de ligação frouxa com o outro. A 
queixa principal é o sentimento de solidão, com ressentimento do egoísmo e da superficialidade nos relacionamentos (RIOS, 2008).

Neste contexto contemporâneo em que está presente esse isolamento, percebe-se uma possibilidade maior de escolhas nas relações. Todavia, esse aumento de possibilidades significa também uma melhora na qualidade dos relacionamentos? E por que essa "expansão de possibilidades" que se dá dentro da era das comunicações ainda não conseguiu diminuir a solidão dos indivíduos?

Buscando investigar o tema da solidão e da sociabilidade na virada do século em Portugal, Teixeira (2001) estudou anúncios pessoais publicados numa revista (Notícias Magazine), uma associação promotora de encontros entre pessoas livres e linhas telefônicas de ajuda. Fica claro, segundo a autora, que a abertura do leque de possibilidades de relacionamentos não corresponde diretamente a uma melhoria na qualidade destes.

Perguntados sobre os elementos mais atrativos no sexo oposto, os homens elegeram a atração física, a voluptuosidade e a sensualidade; as mulheres apontaram, por sua vez, a cultura, a ternura, a inteligência e o carinho.

Os dados da pesquisa parecem apontar que os homens têm dificuldades em lidar com a emancipação feminina, enquanto as mulheres desejam estar mais próximas do chamado relacionamento puro, uma relação de igualdade emocional e sexual.

Nesse sentido afirma Giddens (1995, p. 103), citado por Teixeira (2001):

\begin{abstract}
A igualdade é um elemento intrínseco na transformação da intimidade, como o é a possibilidade de comunicação. A raiva masculina contra as mulheres é hoje, numa medida substancial, uma reação contra a autoafirmação feminina em casa, no trabalho e noutros lugares. As mulheres zangam-se, por sua vez, com os homens devido aos sutis e não tão sutis modos através dos quais eles lhes negam os privilégios materiais que reclamam para si próprias. Pobreza econômica para as mulheres, pobreza emocional para os homens: é este o estado do jogo da relação entre os sexos?
\end{abstract}

Tratar da conjugalidade contemporânea é uma tarefa árdua, uma vez que as transformações sociais, econômicas e culturais se fazem sentir nessa modalidade de relacionamento, em que a relação e as posturas até então conferidas a homens e mulheres passam por um processo de flexibilização. Já é difícil estabelecer de forma categórica e imperativa quais as atribuições de cada um dos parceiros e, nessa medida, o casamento ganhou significados e perspectivas muito particulares para cada indivíduo. 
A experiência da sexualidade foi outro aspecto profundamente afetado por todas essas mudanças, pois hoje se assiste a uma liberação sexual, especialmente para as mulheres. A sexualidade, até então um predicado relacionado ao casamento, atualmente é considerada fundamental para a experiência da intimidade e da união dentro da conjugalidade, além de estar inscrita também nas vivências dos jovens solteiros. A primeira experiência sexual de adolescentes é cada vez mais precoce. 



\section{OBJETIVO}

A proposta deste projeto de pesquisa foi investigar como homens heterossexuais solteiros de camadas médias, de 25 a 35 anos, concebem sua masculinidade, como vivenciam e expressam seus sentimentos, as expectativas a respeito de relacionamentos afetivo-sexuais, suas concepções acerca do casamento e da constituição de uma família. 



\section{METODOLOGIA}

\subsection{Participantes}

Participaram da pesquisa dez homens, heterossexuais e solteiros (com ou sem namorada), entre 26 e 31 anos, pertencentes à classe média. Nove possuem ensino superior completo, sendo um deles pós-graduado.

Para Velho (1985), as camadas médias se apresentam como portadoras mais características da vertente psicologizante das ideologias individualistas. Priorizam a esfera da intimidade e da privacidade, demonstrando, em tese, uma tendência a desqualificar a esfera pública da vida social como referência para sua construção de identificação.

Por outro lado, há um "subjetivismo" das camadas médias, o que propiciou o questionamento e as transformações dos núcleos familiares burgueses - até então vigentes - além do surgimento de modalidades alternativas de identidade e conjugalidade (COSTA, 1996).

A faixa etária foi escolhida porque, de forma geral, essa fase do desenvolvimento está diretamente relacionada à conclusão do ensino superior, ao ingresso no universo do trabalho e também pelas cobranças no que diz respeito à independência financeira, especialmente nas camadas médias.

\subsection{Material}

As entrevistas foram registradas por meio de gravação em fitas K-7. O pesquisador tinha à mão um roteiro de entrevista previamente elaborado, mas que, por ser semi-estruturado, permitia que outras perguntas fossem formuladas quando se considerasse necessário.

Segundo Almeida (2000), citando Benney e Hughes (1956), a entrevista é um objeto de investigação de estudo privilegiado, um modo original de interação, significativo de tipos novos e importantes de relações - entre indivíduos e entre grupos - produzidos pelas sociedades modernas. 
As impressões do pesquisador sobre a situação de entrevista, inclusive o contato anterior e posterior a sua realização, foram registradas em diário de campo.

\subsection{Método}

A pesquisa se baseou em uma abordagem qualitativa, entendida como um conjunto de práticas interpretativas que busca investigar os sentidos que os sujeitos atribuem aos fenômenos e ao conjunto de relações em que eles se inserem (MINAYO, 2006).

O tamanho do universo de entrevistados se justifica pela natureza qualitativa da análise e a escolha dos participantes foi bastante cuidadosa, buscando-se certa homogeneidade nas condições vividas pelos sujeitos, no que se refere à idade, ao nível de instrução, à renda mensal e ao estado civil.

Buscou-se caracterizar de forma abrangente os entrevistados, no que tange a informações pessoais e profissionais, e tornar o clima da entrevista agradável e favorável ao participante, a fim de se reunir uma quantidade relevante de dados a serem analisados e articulados entre si.

Ao cruzar dados, fazer comparações entre diversos tipos de discurso, confrontar depoimentos de diferentes indivíduos a respeito de uma realidade, é construída a tessitura da vida social em que valores, emoções e atitudes estão inscritos. Sem estes recursos, segundo Fonseca (1999), é possível que se alcance uma visão simplificada e incompleta da realidade.

Como complemento à coleta de dados através de entrevista lançou-se mão também da utilização de um Diário de Campo, um instrumento complexo que permite o detalhamento de informações, reflexões e observações sugeridas no decorrer da investigação ou no momento observado (BOGDAN; BIKLEN, 1994). O Diário de Campo foi composto por notas descritivas, como o ambiente da entrevista, a sequência em que os fatos ocorreram, e por notas analíticas, correspondentes às reflexões pessoais do pesquisador. 


\subsection{Procedimento}

Inicialmente o projeto e o roteiro de entrevista (Anexo A) foram submetidos ao Comitê de Ética da Faculdade de Filosofia, Ciências e Letras de Ribeirão Preto (FFCLRP-USP), para que fossem avaliados. Após aprovação do projeto por esse Comitê (Anexo B), deu-se início à coleta de dados. O roteiro de entrevista foi submetido a um pré-teste a fim de avaliar a adequação do roteiro e a formulação das perguntas apresentadas. Como essa entrevista trouxe resultados bastante interessantes para a pesquisa, optou-se por utilizá-la na análise dos dados.

Em primeiro lugar, o acesso aos sujeitos foi facilitado por pessoas do círculo de relações do pesquisador, que indicaram conhecidos que possuíssem características próximas às exigidas pelo projeto (homens heterossexuais, solteiros com ou sem namorada, de camadas médias, entre 25 e 35 anos). A partir disso, foi feita uma seleção de possíveis participantes para a pesquisa.

$\mathrm{O}$ pesquisador fez contato com onze jovens, havendo apenas uma recusa. $\mathrm{O}$ contato inicial com todos os entrevistados foi feito por telefone e, com o aceite do convite, eram combinados local, data e horário convenientes para a realização da entrevista. Das dez entrevistas realizadas, nove ocorreram na casa dos participantes e apenas uma se deu no local de trabalho do sujeito.

Após a apresentação do pesquisador e dos objetivos e métodos de estudo, foi perguntado ao jovem se este aceitava participar da pesquisa e se permitiria a gravação da entrevista. Enfatizou-se que a participação deveria ser inteiramente voluntária e foi garantido aos entrevistados sigilo sobre as informações reveladas e que suas identidades seriam mantidas no anonimato. Além disso, foi explicado que ele poderia interromper a entrevista a qualquer momento e que poderia recusar-se a responder qualquer pergunta que fosse feita.

Por questões éticas, foi apresentado o Termo de Consentimento Livre e Esclarecido (Anexo C), a fim de que o participante o lesse e, caso concordasse com seu conteúdo, o assinasse autorizando a utilização dos dados.

A entrevista foi dividida por temas gerais (Infância e Adolescência, a Condição Masculina, Relações Afetivo-Sexuais, Casamento, Família e Filhos), que deram abertura a outros pontos específicos, relevantes à pesquisa. Os temas foram abordados 
pelo pesquisador previamente ao início das perguntas, de maneira resumida, a fim de introduzir ao participante sobre o que tratariam.

Procedeu-se então à realização da entrevista e, ao final desta, solicitou-se ao entrevistado que indicasse outro jovem que se encaixasse no perfil estabelecido para realização da pesquisa.

Após a realização da entrevista, o pesquisador registrou em diário de campo suas impressões, observações e reflexões acerca do processo da entrevista.

Todas as entrevistas, após serem realizadas, foram transcritas. 


\title{
4. RESULTADOS E DISCUSSÃO
}

Neste item são apresentados os resultados obtidos com as entrevistas, acompanhados de suas análises, bem como a apresentação de informações que constam no diário de campo.

Apresenta-se a seguir uma breve caracterização de cada um dos participantes, ressaltando-se que os todos os nomes utilizados, inclusive as referências feitas a terceiros pelos entrevistados, são fictícios.

\begin{abstract}
Aluísio
26 anos, graduado em Administração de Empresas, mestrando em Administração, consultor na área de finanças, renda mensal de aproximadamente R \$3.000,00. Mora com os pais, um irmão mais novo e a avó materna, não tem namorada.
\end{abstract}

Bernardo

29 anos, graduado em Direito, advogado, renda mensal aproximada de R \$ 1.800,00. Mora com a mãe, sem namorada.

\section{Eduardo}

29 anos, graduando do curso de Audiovisual, produtor e editor de filmes, renda mensal aproximada de $\mathrm{R} \$ 1.500,00$. Namora há dois anos e meio e mora com a namorada há cerca de um mês.

\section{Glauber}

29 anos, graduado em Comunicação Social, publicitário, trabalha na área de mídia, renda mensal de aproximadamente $\mathrm{R} \$ 2000,00$. Mora com os pais e dois irmãos mais novos. Marcos, também entrevistado, é seu irmão. Namora há três anos.

\section{Leandro}

28 anos, graduado em Administração Pública, trabalha como analista de engenharia pleno, renda mensal aproximada de R \$ 2500,00. Mora com a mãe, uma irmã mais velha e um irmão mais novo. Sem namorada. 


\section{Sérgio}

31 anos, pós-graduado em Administração, trabalha em uma operadora de telefonia celular, renda aproximada de $\mathrm{R} \$ 3500,00$. Mora sozinho, sem namorada e tem um filho de um ano.

\section{Lucas}

27 anos, graduado em Administração Pública, trabalha como analista de rotas em logística, renda mensal aproximada de $\mathrm{R} \$ 2000,00$. Mora com dois amigos e namora há um ano e três meses.

\section{Marcos}

26 anos, graduado em Administração, trabalha no setor de eventos de uma escola da cidade e tem uma empresa de recreação e lazer infantil. Renda mensal aproximada de $\mathrm{R} \$ 3.500,00$, mora com os pais e dois irmãos, namora há nove anos. É o irmão do meio de Glauber.

\section{Guilherme}

30 anos, graduado em Administração, cursa mestrado na área, trabalha como professor universitário e tem um site de ensino à distância, renda mensal de aproximadamente $\mathrm{R} \$ 3.500,00$. Mora com a mãe e o padrasto, namora há três anos.

Fábio

30 anos, trabalha como técnico em arte dramática, é também bartender, modelo e ator publicitário, com renda mensal de R \$ 1.500,00. Mora com um amigo, sem namorada.

\subsection{Infância e Adolescência}

[...] Eu não gostei muito da minha infância, nem da minha adolescência, eu prefiro o que eu vivo hoje muito mais do que o meu passado. (Aluísio)

[...] Muita afinidade, muita afinidade pra viajar, pra confidência, pra tudo, né, então um relacionamento muito bacana. Tanto é que até 
Questionados a respeito de como foram a infância e a adolescência, os entrevistados responderam relacionando tais fases do desenvolvimento principalmente a atividades que realizavam na escola, com familiares e amigos. Alguns deles pontuaram as dificuldades de relacionamento com os colegas, em especial na escola, descrevendo conflitos e angústias que experienciaram:

Eu acho que eu tive uma infância legal até, eu pude brincar bastante, mas meio conturbada [...] Me usavam de bode expiatório, então eu sofri muito [...] Hoje eu sei que isso daí, tipo assim, me deixou meio com a auto-estima baixa, às vezes eu me sinto incapaz de fazer as coisas [...] Sempre foi na escola esses problemas e isso aí eu acho que marcou muito na minha vida, até a maneira como eu me tornei homem e como eu sou hoje. (Aluísio)

Eu acho que a grande dificuldade que eu tive na minha infância era que eu era muito ruim de esportes, eu sempre fui muito ruim e aí... Era sempre o último a ser escolhido no time de futebol, sabe essas coisas assim? Era meio traumático. (Guilherme)

No ensino infantil, eu era um pouco folgado, porque a minha mãe era dona da escola, então, tipo, eu me achava o dono da escola, não achava que eu era um aluno como os outros. Aí a minha mãe me expulsou da escola dela e me botou numa escola particular, porque eu tava dando muito trabalho (Bernardo)

[...] Eu cheguei na sala de aula, eu era novato, então eu apanhava todo dia [...] Aí chegou um outro novato e esse pessoal, veterano, chegou pra mim e falou: "É o seguinte: se você não bater naquele cara, a gente vai continuar te batendo o ano inteiro". Então, tecnicamente, eu levantei e fui lá e bati no moleque porque eu não queria apanhar o resto do ano. Então, assim, foi meio complicada a parte da escola. (Eduardo)

De acordo com Knobel (1981), a adolescência é definida como a etapa da vida em que o indivíduo procura estabelecer sua identidade adulta, apoiando-se nas primeiras relações objeto-parentais internalizadas e avaliando a realidade do meio social em que vive por meio do uso de elementos à disposição e que tendem à estabilidade da personalidade em um plano genital, o que se torna possível somente quando se dá o luto pela identidade infantil.

Durante essa fase, o indivíduo sofre influências biológicas, e seu corpo passa por transformações profundas à sua revelia, com repercussões psicológicas, como a 
elaboração do luto pela perda do corpo e identidade infantis e a reformulação de conceitos a respeito de si e dos outros. Essas mudanças, por vezes contraditórias, também repercutem na esfera social, uma vez que, em alguns momentos é exigido dele uma postura adulta e, em outros, é colocado na posição de criança, muitas vezes pela própria insegurança dos adultos, os quais também sofrem influência das mudanças ocorridas com o adolescente.

Segundo Aberastury (1983, p.16), a adolescência é

[...] um período de contradições, confuso, ambivalente, doloroso, caracterizado por fricções com o meio familiar e o ambiente circundante. Este quadro é com frequência confundido com crise e estados patológicos, o que alarma o adulto e o leva a buscar soluções equivocadas.

A adolescência é descrita pelos entrevistados como um período de transformações importantes, em que se nota uma valorização da sociabilidade entre os pares. Emerge a busca pela independência em relação aos pais e a luta pela construção de uma identidade única e singular:

[...] A gente dependia dos pais, eles nunca foram bem, bem assim de vida [...] Na época, eu era promoter das baladinhas, então eu conseguia convite pra todo mundo ir, eu dava um jeito de ir, sabe, pra evitar problema com os pais, né, ficar mais independente um pouco. Desde cedo eu fui assim (Marcos)

Adolescência, aí eu já julgo que foi um pouco mais complicado, porque, assim, adolescente costuma ser um pouco cruel em certos aspectos. E eu sempre fui o melhor aluno da sala e isso normalmente me gerava um certo nível de problema na adolescência (Guilherme)

Segundo Calligaris (2000), a finalidade da adolescência repousa sobre o desejo do adolescente em ser adulto. Todavia, ainda que esteja maduro no corpo e no espírito para lançar-se a essa condição, não pode fazê-lo por uma "moratória": para o reconhecimento de sua condição de adulto, é necessário um tempo de espera. Entretanto, um problema se apresenta nesse contexto, já que ao ordenar que o adolescente seja independente e autônomo, a sociedade acaba por induzir a 
desobediência da moratória, isto é, para haver o reconhecimento, o adolescente não deve se conformar.

Ao falar sobre o relacionamento com os pais, alguns dos jovens ainda destacam com qual deles se identificavam mais ou com quem possuíam maior afinidade:

Minha mãe é o meu referencial, não é o meu pai, minha mãe, minha mãe às vezes é pai, sabe? (Aluísio)

[...] Eu sempre tive mais uma ligação muito grande com a minha mãe, só que a minha proximidade era maior com o meu pai, né, pra... Digamos que o pai era aquele lado mais humano e a mãe era aquele lado mais que puxava pra trabalho, pra responsabilidade, né, e o pai era o lado que puxava mais pro relacionamento [...] (Sérgio)

[...] Os relacionamentos com os meus pais sempre foram, assim, razoáveis, vamos dizer assim, com o meu pai melhor do que com a minha mãe. Mãe tem aquela coisa, né, um pouco de... Como eu vou te dizer? Com o menino, ela fica tentando impor e a gente fica naquela... Menino é meio desafiador, né, não gosta muito de imposição, com o meu pai eu acabava me dando melhor (Guilherme)

Um aspecto mencionado por quase todos os entrevistados refere-se ao relacionamento com as mulheres. Observa-se que há um cuidado por parte de alguns participantes em ressaltar não só as conquistas afetivas, mas também as decepções e as dificuldades nos relacionamentos. A adolescência, na fala dos jovens, parece ganhar mais sentido a partir do momento em que é possível impressionar e conquistar o sexo oposto, considerado quase que um "troféu" para eles.

Para Gikovate (2004), impressionar as mulheres significa fazer coisas diferentes das usualmente feitas, tem o sentido de se destacar, se diferenciar da média de alguma maneira, o que pode ser percebido na voz de Marcos:

Por a gente gostar muito de dançar, a gente ir nessas festas, assim, a gente dançava, por ter um grupo de dança, as meninas se aproximavam bastante. Então a gente era popular, a gente acabou ficando popular [...] (Marcos)

Outros entrevistados também relatam como se comportavam na arte da conquista feminina:

Referente a mulheres, eu era um cara que ficava com bastante menina, ia nas festinhas, tal, naquela época em São Paulo era moda as baladinhas dance, então ia bastante, na própria escola mesmo, ficava com as meninas, bem ficar mesmo, naquela época, só. (Lucas) 
A adolescência foi foda numas coisas [...] O meu óculos era grosso, eu morria de vergonha de chegar perto das meninas, não beijava nenhuma, era uma coisa meio foda. E aí elas tiravam o meu óculos, às vezes, "Fica melhor sem óculos", era grosso, porra! (Fábio)

Eu tinha mais problema com relacionamento com mulheres mesmo, porque assim: eu não conseguia ter relacionamento como eu gostaria de ter, como a maioria dos meus amigos. Então sempre gostava da menina que não gostava de mim e a menina que gostava de mim, eu não tava nem aí. Então assim, eu sempre fiquei lá batalhando: "Nossa, como que eu gostaria de ter uma namorada...", de ter... E não tinha facilidade nisso. [...] Vou contar desde a primeira vez que eu tive contato com mulher, eu tinha 12 anos, eu fui namorar a primeira vez assim, sério, com 18. Então eu fiquei seis anos assim, só... (Glauber)

A fala de Glauber expressa de forma semelhante o que Gikovate (2004 p.122) também descreve a esse respeito:

O rapaz sofre, se entristece pelo amor não correspondido. Se existirem outras moças interessadas nele, isto não o consolará. Ele queria aquela que lhe parece especial; e esta não o quer. [...] Os jovens sofrem, mas seu coração está repleto de esperanças e sonhos.

Ainda para Gikovate (2004), os rapazes que cresceram com maiores inseguranças se colocam de uma forma muito mais tímida e comedida em relação às moças. Em geral, são receosos de que elas percebam seus interesses mais claramente sexuais e de ofendê-las agindo de modo mais explícito, uma vez que elas se comportam de uma forma que permite que eles pensem desse modo. Temem ainda, principalmente, a rejeição delas e se sentem inferiorizados em relação a elas e aos outros rapazes.

Nas falas de alguns entrevistados, nota-se a presença de um valor precioso de masculinidade e potência associado à capacidade de beijar muitas meninas. Ser o "pegador", o "garanhão" é um papel desejado pelo rapaz, o que garante um respaldo e um respeito entre os amigos e, principalmente, entre os grupos femininos. É, de certa maneira, livrar-se da possibilidade de ser ridicularizado por uma suposta incompetência em abordar as mulheres e ser chamado de "fraco" ou - o que seria muito pior para eles de ter a sua virilidade e heterossexualidade postas em questionamento pelos amigos.

Por outro lado, o incômodo devido à dificuldade em se relacionar com o sexo oposto fica claro nas falas de Aluísio e Fábio:

[...] Pra você ter uma idéia eu fui beijar minha primeira menina aos 18 anos de idade, entendeu? Eu não conseguia, eu era gordinho, eu tinha trauma de ser gordinho, eu era bem gordinho, aliás... Eu me sentia 
horrível, feio, minha auto-estima até hoje é baixa, mas lá era pior ainda. Então não tinha, não conversava com as mulheres, só tinha os meus amigos, que eram poucos. Não tinha contato nenhum, eu achava meio que impossível conversar com as meninas, sabe? (Aluísio)

Pô, eu beijei a primeira vez foi o quê? Eu tinha nove anos de idade... Não, a menina tinha nove e eu tinha onze. Foi ótimo, né, todo mundo queria beijar, tal... Mas eu era tímido de me aproximar, tanto é que essa menina, ela que se jogou mais, aí foi melhor, entendeu? Porque eu tinha aquela barreira dos óculos, aquela proteção. (Fábio)

Leandro ainda destaca o papel da natação, que contribuiu para construir laços com iguais e, inclusive, namorar, bem como lidar com a frustração de ter sido traído pela primeira namorada:

Fez parte, fez parte, em termos de relacionamento, a minha primeira namorada nadava comigo... Minha segunda nadava comigo, meu primeiro beijo foi dentro da natação [...] Nunca fui namorador de moleque, sempre fui mais quieto, tive uma primeira namorada na oitava série que me chifrou e aí o bicho pegou, cê é moleque, a mulher mais velha, cê fica: "Puta, que azar!".

Mesmo para aqueles que afirmam ter tido uma maior facilidade de relacionamento, ainda assim se nota a presença de ambiguidades e dilemas próprios dos adolescentes:

Eu comecei a namorar muito cedo, eu comecei a namorar, tipo, com 13 anos. E aí eu levava isso muito a sério [...] E isso eu acho que é uma coisa que me prejudica bastante até hoje ainda... [...] Porque eu sempre sinto que eu não tenho, que eu não aproveitei, tipo, pra ficar, pra zoar quando eu deveria, que eu namorei mais do que eu deveria ter namorado. (Bernardo)

[...] Com as meninas eu tive um pouco de dificuldade, mesmo porque eu era muito exigente, digamos assim. Eu sempre fui um cara que assim, "Eu quero aquela, tem que ser aquela, não pode ser outra", entendeu? [...] Mas, sempre assim, eu sempre me dei até relativamente bem dentro do que eu esperava, a minha maior dificuldade era mesmo com outros homens, na verdade, eu não me dava muito bem [...] Eu contava nos dedos os meus amigos homens [...] (Guilherme)

Esse panorama de pressões, mudanças e contradições vivenciadas trazem dificuldades na análise do comportamento do adolescente. Para Knobel (1981) é muito complexo definir o limite entre o normal e o patológico na adolescência e a comoção desse período deve ser considerada normal, assinalando também que seria anormal a presença de um equilíbrio estável durante o processo de viver a adolescência. 
Para Erikson (1972), o problema chave da identidade adolescente seria a capacidade de manter a semelhança e a continuidade frente a um desenvolvimento que é mutável. A situação mutável presente na adolescência obriga a reestruturações permanentes, internas e externas, vividas como intrusões dentro do equilíbrio conquistado na infância e que obrigam o adolescente, no processo de conquistar a sua identidade, a tentar refugiar-se ferreamente em seu passado enquanto tenta também se projetar intensamente no futuro. As mudanças corporais que se dão de maneira acentuada na adolescência trazem um sentimento de despersonalização que contribui para a crise de identidade vivida.

Entretanto, a dificuldade nos relacionamentos com os colegas durante a infância e adolescência, mais explícita nas falas de Guilherme e Aluísio, parece ficar mais diluída quando estes se tornam mais velhos e ingressam na faculdade. Outra fase, outro momento de vida, outros colegas, nova rotina e nova forma de sociabilidade a ser vivida. O depoimento de Guilherme ajuda a ilustrar esse outro momento de experiências:

[...] Eu ganhei um espaço pessoal muito grande, assim, que eu passei a ser respeitado, porque na faculdade a coisa muda, cê tá ali, tem pessoas no mesmo nível que você, então não tem mais aquele jogo de você ser o $\mathrm{CDF}$ da sala, porque todo mundo é um pouco $\mathrm{CDF}$, na faculdade pública, né? (Guilherme)

\subsection{A condição masculina}

Eu não fico tanto com aquela imagem que homem é aquele que vê TV, futebol na TV no domingo e sai pra beber cerveja com os amigos de sexta-feira, porque eu não sou assim. E eu sou homem, mas, pra mim é isso, é cuidar mesmo. (Aluísio)

Ser homem é você ter caráter, é você tentar fazer das pessoas que tão mais perto de você, seu melhor amigo, às vezes. (Fábio)

Eu acho que o homem acaba sendo aquela eterna criança, no final das contas, eu me vejo como uma criança que não cresceu, que... Assim, só mudou o tamanho do brinquedo. (Guilherme) 
A primeira questão dirigida aos entrevistados sobre a condição masculina foi: "O que significa ser homem para você?". Foi uma pergunta que gerou muitas dificuldades para ser respondida por alguns entrevistados, o que pode ser percebido nas falas abaixo:

Nossa, cara, cê sabe que eu nunca parei pra pensar nisso! (Guilherme)

Ser homem? Eu não sei cara, se eu sei te responder o que significa. Eu não penso muito diferente, tipo homem e mulher, ser homem é ser uma pessoa, né? Não sei, não sei te responder essa pergunta, de verdade. (Bernardo)

Cê diz em que termos? [...] Ah, cara, é uma pergunta meio difícil. (Lucas)

O que significa ser homem? Nossa, que pergunta! Nossa, tá difícil responder isso! [...] Deixa eu pensar... (Marcos)

Essa dificuldade em refletir a respeito do que é ser homem também foi notada de forma geral por Gomes, Nascimento e Araújo (2007), especialmente entre entrevistados de baixa ou nenhuma escolaridade. Ainda que os entrevistados desta pesquisa possuam alto nível de instrução, esse problema foi encontrado nas respostas (ou na falta delas. Esse dado levanta um possível questionamento: a dificuldade em refletir acerca da própria condição masculina abrange todas as classes sociais?

Observa-se, a partir das falas a essa primeira pergunta e por relatos ao longo da entrevista, que a reflexão acerca da condição masculina não é realizada de forma profunda, quais sentidos, valores, atitudes e comportamentos são avaliados e pensados pelos sujeitos. Falas como "Eu nunca tinha pensado nisso antes”, "Nunca parei para pensar nisso", "Ninguém nunca tinha me perguntado isso" e expressões de surpresa permearam a grande maioria das entrevistas.

Fala-se, e muito, do verdadeiro significado do que é ser homem na contemporaneidade, talvez como resultado de sua inserção na cultura à qual pertence, onde, por conseguinte, precisa moldar-se sustentando ou criticando, aderindo ou rejeitando, integrando-se ou afastando-se, obedecendo ou resistindo às regras impostas pela cultura e definidas como normas, conformando características, comportamentos e papéis que não necessariamente sejam aqueles que condizem com aquilo que ele almeja para si enquanto traços identificatórios. 
As respostas variaram bastante em relação a essa pergunta. Alguns dos entrevistados relacionaram o significado de ser homem à assunção de papéis e funções, a valores morais e éticos, a características masculinas em contraposição às femininas, inclusive destacando a importância da diferença biológica entre os sexos:

Eu vejo o homem como um bicho um tanto quanto rústico, eu vejo um pouco da agressividade como algo inerente do ser masculino, né, a gente, diferente do que as pessoas falam, eu acho que a gente é mais impulsivo do que as mulheres no geral [...] Uma rusticidade misturada com um tanto de imaturidade no meio, que faz tudo parte desse parte desse pacote de ser homem [...] (Guilherme)

[...] Esse negócio de ser homem, eu acho muito complicado. Assim, o que é ser homem? Eu acho que eu ainda sou um pouco machista, naquilo de achar que tem que prover, sei lá, isso é parte minha. Eu acho que ser homem é cuidar [...] (Aluísio)

É ter responsabilidade, ter, vamos dizer assim, ética, né, respeito, é você saber se conduzir na sua vida, né, não perante a si mesmo, mas aos outros e à sociedade [...] (Eduardo)

Eu vejo que o homem hoje [...] Ainda vejo como o provedor da casa, como o responsável pela parte mais racional da criação dos filhos [...] Eu vejo o homem como também responsável por uma segurança, principalmente quando se fala em família [...] Não sei, acho que assumir o fator homem, né, sinceridade, honestidade, assumir as responsabilidades, o trabalho... (Sérgio)

[...] Eu fui criado com um jeito de homem, tipo, de o cara tem que ser decente, tem que ser honesto, tem que ser sincero, tem que assumir seus atos, tem que ser pai de família mesmo, tem que batalhar, trabalhar pra por comida em casa, sabe? Respeitar a mulher, filhos... (Leandro)

Ser homem pra mim é não depender de outro homem, é não depender de ser humano... Não que isso seja... É você assumir talvez um pouco o seu egoísmo, numa boa, falar assim: "Eu tenho pontos egoístas sim" e não ficar se fazendo de santo. Eu confio mais na bondade que assume o seu egoísmo e fala e é isso que eu percebo que eu tenho que achar pras coisas darem certo, às vezes. (Fábio)

O homem como um ser dominador e dotado de superioridade em relação às mulheres também é descrito nos depoimentos dos irmãos Glauber e Marcos:

$\mathrm{Eu}$ acredito que o homem ainda é o que consegue colocar o pé no chão porque ele vai mais pela razão das coisas [...] Eu acredito que o homem ainda tenha um papel mais importante na sociedade [...] Não que eu seja machista, mas eu acho que seria a parte mais importante ainda na sociedade, né, porque se você for analisar os animais, o que caça ainda é o macho, né? (Glauber) 
Sem querer ser muito machista, mas eu acho que o homem é a base, é a base de tudo. [...] E cê vê que hoje em dia, quem lidera, a maioria das lideranças aí são tudo homem, agora que as mulheres começaram a dar a cara, né? [...] Porque mulher, não que se espelha, mas acho que mulher é muito mais dependente do homem que o homem da mulher, eu acho. (Marcos)

$\mathrm{O}$ atributo de dominador é ainda um ponto relevante muito comum que serve de referência para a construção da identidade masculina. Nas falas de Glauber e Marcos, percebe-se que o homem é considerado o alicerce da família e, apesar do avanço feminino em diversas esferas sociais, o papel de líder da família ainda cabe a ele. Para Nascimento e Gomes (2008), ainda há resquícios da marca da masculinidade ligada à dominação, que continua a sustentar privilégios materiais, simbólicos e culturais dos homens em relação às mulheres, mantendo desiguais as relações de gênero.

Lucas, por sua vez, relaciona o ser homem à condição heterossexual:

Ser homem, primeiramente, é ser uma pessoa $100 \%$ heterossexual [...] Pode até ser uma visão meio machista, pra mim não tem essa de "Ah, eu já tive alguns relacionamentos com homens, com mulheres, mas eu sou homem".

Interessante notar que, ao contrário da forma como alguns homens se descrevem, a maioria dos entrevistados não associa diretamente o ser homem com "o não ser mulher" e "o não ser homossexual", mas o faz com base nas contraposições entre padrões masculinos e femininos. Ainda que a construção da identidade masculina muitas vezes se dê com base nessas negações - da feminilidade e da homossexualidade os entrevistados trazem em suas respostas atributos que julgam realmente pertencentes ao homem.

Tornar-se homem, para esses jovens, relaciona-se diretamente com a incorporação das responsabilidades esperadas do sexo masculino. A figura do provedor, bastante mencionada por eles, está diretamente relacionada a duas esferas concretas: o trabalho e a família, que são dois pilares para a inserção e o reconhecimento masculino. As falas acima podem também sugerir que exercer a masculinidade deve assegurar uma ligação entre a reprodução biológica e social da família (NASCIMENTO; GOMES, 2008).

A associação entre ser homem e ser provedor ainda está muito presente no imaginário social. Em um estudo realizado com uma amostra de dois mil indivíduos 
maiores de 18 anos, em 24 estados brasileiros, ressaltou-se uma forte ligação entre a função de prover e a figura masculina. (OLIVEIRA, 2005).

Quanto à construção do ser homem, alguns sujeitos elegeram as relações sociais, com familiares e amigos como um dos principais meios para sua realização. A independência em relação aos pais, não só do ponto de vista financeiro, mas psicológico, também se faz presente em alguns dos depoimentos:

Eu acho que responsabilidade, eu acho que você... Cê não precisa fazer o que os outros esperam que você faça, cê tem que fazer o que você acha que você tem que fazer. Você tem que não falhar com as suas expectativas. (Bernardo)

O homem, pra ele ser um homem, primeira coisa: ele tem que se portar como um, né? Ele tem que saber onde ele... Se impor, ele tem que saber o que é de direito dele, eu acho que ele tem que saber como se portar diante da sociedade, diante dos seus descendentes, se mostrar uma pessoa capaz de ser um líder, de defender, de ter o seu ponto de vista, ter respeito, ter bom caráter... (Glauber)

Eu acho que a família, a educação, acima de tudo, é o que faz você se tornar o que você é. [...] A educação que eu tive, não só dentro de casa, mas fora de casa também, pra te trazer conhecimento, eu acho que isso constrói um homem, as amizades que ele anda constroem ele também, sabe? Ele começar a entender e a criar a sua personalidade própria. (Leandro)

Eu acho que a partir do momento em que você se liberta dos seus pais, cê começa a trabalhar, cê começa a ter as suas responsabilidades, principalmente do lado financeiro, o lado de relacionamento também, né? (Sérgio)

[...] Tornar-se homem de verdade é cortar uma relação de dependência de pai e mãe, financeira, mas principalmente afetiva e começar a dirigir a sua própria vida, sem a influência deles. (Aluísio)

Uma coisa que talvez ajude a tornar o homem mais homem seja o fato de você, na fase da infância e da adolescência mesmo, largar o cara um pouco por sua conta, digamos assim, entendeu? Ter um pouco menos de paternalismo [...] (Guilherme)

Ainda nesse sentido, Leandro acrescenta que é fundamental que o homem se defina em termos de prioridades em sua vida, para que a partir dessa definição ele trace seu próprio caminho, com objetivos bem estabelecidos, o que traria menos conflitos a serem enfrentados.

Pode ser observado que o caráter biológico do homem é menos enfatizado pela maioria dos entrevistados quando se trata da construção da identidade masculina. 
Aluísio aponta que a ocorrência da primeira relação sexual também torna alguém um homem e Guilherme enfatiza a agressividade masculina como algo inato ao masculino. Os valores sociais parecem ter um papel mais relevante para os entrevistados em detrimento dos aspectos biológicos.

O papel social de provedor, diretamente relacionado ao sexo masculino pelos participantes, é historicamente datado, mas os estudos de gênero dos homens dos anos 1970 o tornaram universal, postulando que é uma característica fundamental do ser masculino (CONNELL, 1995a). A identificação masculina com a independência e a auto-suficiência e, posteriormente, com o trabalho fica clara nas falas de Guilherme e Fábio:

[...] O homem se identifica muito com a sua profissão, você chega e pergunta: "Fulano!", cê não quer saber onde o cara mora, a primeira pergunta que as pessoas fazem é: "O que você faz?" [...] Talvez isso cause um medo, né, como você se identifica pelo que você faz, você quer sempre também ser o melhor possível naquilo. (Guilherme)

Eu acho que isso é ser homem, é você passar pra frente, porque eu acho que o homem é o trabalho dele, cara. Eu percebi isso, tem até uma frase que é até assim: "O homem ama a mulher. A mulher ama o trabalho do homem", entendeu? Isso pode ser meio irônico, mas eu acho que é isso que acontece. Porque a mulher, ela te vê diferente a partir do momento em que você se mostra um trabalhador, por exemplo, umas coisas que você sabe que tá se virando, que você é auto-suficiente. A mulher busca essa segurança, entendeu, assim, em mínimos detalhes. (Fábio)

Os depoimentos acima vão ao encontro do que Seidler (1991) aponta a respeito da relação masculina com o trabalho. $\mathrm{O}$ autor acima pontua que os homens precisam se tratar como objetos, como indivíduos competitivos, tanto para manter o ritmo do trabalho, que não controlam, como na supressão de sentimentos de raiva e ressentimentos que são originários da falta de poder nessa relação. Esse panorama pode também ser visualizado ainda em uma das falas de Guilherme:

Até a forma com a qual a gente aborda o trabalho é um risco contra a nossa própria saúde. O homem aborda o trabalho com um nível de seriedade que às vezes compromete não só a saúde, como o próprio núcleo familiar.

Percebe-se que a identificação masculina com o trabalho afeta diretamente a forma como os homens estabelecem seus relacionamentos e também traz prejuízos à saúde masculina. Guilherme é quem mais toca nesse assunto, dizendo que o homem 
sofre uma pressão diferente daquela vivida pelas mulheres. Enquanto estas sofrem para encontrar seu espaço no mercado de trabalho, os homens são pressionados a assumir a função de provedor, o que para ele geraria dúvidas na definição da própria carreira profissional a seguir. A maior dificuldade para esse entrevistado seria garantir o sustento familiar, função que em geral recai sobre os homens.

O trabalho é a principal forma de inserção no mundo público e, desse modo, uma das bases sobre a qual se edifica a identidade masculina tradicional. Segundo Wang (2004), em alguns casos o sucesso profissional pode ser confundido com realização pessoal, tamanha a importância na vida do homem.

Além disso, também se perguntou aos jovens quais os valores mais importantes para a sua formação enquanto homem. Valores como honestidade, responsabilidade, respeito e sinceridade foram os mais citados pelos entrevistados:

Honestidade eu acho fundamental, honestidade com os outros, com a família, eu acho isso imprescindível. Ser sincero, que tá um pouco relacionado à honestidade, que é ser verdadeiro, na medida do possível, porque às vezes não dá pra ser tão verdadeiro. (Aluísio)

Eu acho que a verdade mesmo, a sinceridade, a questão de não ter a preguiça que eu te falei, ser um "bom vivant", ser sempre bom com os outros, mas não ser bobo também, né? (Marcos)

Eu acho que é a dignidade, o respeito, coragem, responsabilidade, humildade... O que mais? Honestidade... (Glauber)

Acho que honestidade, responsabilidade, prudência também, né, respeito, eu acho que esses são os principais. Não existe um ou outro, é um conjunto inteiro, mas eu acho que esses são a base: responsabilidade, respeito, honestidade... (Eduardo)

O caráter eu acho muito importante... A disciplina... Responsabilidade... Acho que esses são os principais. (Sérgio)

Somente Fábio elegeu a fé como um elemento essencial em sua vida:

[...] A fé eu acho que é um valor muito importante, é o que faz a gente não fazer coisas extremamente erradas. Porque existe esse Deus e a gente tem essa relação de tradição, e chega um momento que a gente volta nessa fé sempre pra não fazer o pior (Fábio)

Um ponto significativo a ser ressaltado nas respostas é o destaque dado à importância da família para a construção do caráter dos participantes, especialmente por Bernardo e Leandro: 
Eu acho que uma coisa importante é família, uma coisa que eu tenho pra mim que é uma coisa muito importante [...] (Bernardo)

É entender o que é a família, aí cê abre o leque dentro da família, do amor, do caráter da sua família, da dedicação interna ali, da sua família, de como você foi criado, da educação que cê teve ali, eu acho que são os maiores valores pra mim, pra sair pra fora aí... Entendeu? (Leandro)

\subsection{As vivências masculinas}

\begin{abstract}
Cê não vê homem sair em dois assim, homem, se ele vai sair, ele chama quatro, cinco, já marca um futebol, ou vai jogar sinuca, ou vamo fazer um churrasco, ou, porra, não tem nada pra fazer, vamo tomar uma cerveja ali na esquina? (Bernardo)
\end{abstract}

Homem, por exemplo, tem uma tendência muito grande a brigar, o contato físico mesmo. Todo homem tem uma paciência menor pra lidar com determinadas situações e prefere o contato físico. Isso é uma coisa clássica, diferencia muito mais das mulheres. (Lucas)

Perguntou-se aos entrevistados quais são as situações mais comuns vividas pelos homens, tanto de forma geral quanto de forma pontual. Um aspecto encontrado em praticamente todos os entrevistados foi que se referiram, em um primeiro momento, a situações gerais e alguns ainda tiveram dificuldades em apontar situações comuns e específicas que geralmente ocorrem na vida de um homem. Os jovens apontaram situações mais ligadas à sociabilidade masculina, como o relacionamento entre os homens e também com as mulheres:

Eu acho que o que mais acontece com o homem, eu acho que o homem é mais social do que a mulher, o homem procura, tipo, jogar bola com os amigos, ou fazer um churrasco com os amigos, eu acho que o homem se reúne mais entre homens [...] (Bernardo)

Ele sempre tá a procura de um trabalho legal pra poder ter uma grana legal, ter um carro legal, principalmente pra quê? Pra conquistar uma mulher legal e ele ter um relacionamento, né? Essa eu acho que a maioria dos homens faz isso, ele procura sempre ter as coisas pra 
conseguir ter mulheres, ele nunca procura a mulher primeiro pra depois ter as coisas. (Glauber)

Competição, em relação a tudo, em relação a outros homens, em relação a outros profissionais no trabalho, em relação a tudo. Eu acho que a essência do negócio é a competição, é a luta pelo terreno, a luta pela fêmea, digamos assim, então eu acho que a gente ainda tá muito no lado animal da coisa, modo de dizer. (Sérgio)

O cara sair e falar: "Ah, comi não sem quem, comi não sei quem", isso acontece muito, né? E isso vem do homem, a mulher não faz isso, é muito difícil. Daí quando a mulher começa a fazer isso, aí ela é vagabunda, aí ela é não sei o quê. Agora o homem não, o homem é o cara, né, se ele sai dali, ele vai, pega duas numa noite, isso pro homem é mérito, pra mulher já não é, né? (Marcos)

Todo homem bate punheta, né, a masturbação. É isso, bicho, o cara pode tá namorando, o cara pode tá amando a mulher, tudo, aliás... Até pra não trair é uma coisa saudável, porra, se você tá com uma mulher que você ama, a masturbação é um meio... (Fábio)

Eu acho que todo homem tem aquele medo da paquera, de tomar um fora no flerte, né, tem o medo do chifre e é também muito comum, todo homem tem isso. (Guilherme)

A respeito de situações que só acontecem com homens, os entrevistados se dividiram. A maioria afirmou que não há mais situações exclusivas para cada sexo, e outros citaram situações que, em sua opinião, ocorrem somente com homens:

Eu não vejo muita coisa que só acontecem com homens, praticamente tudo tá aí... Hoje em dia, tudo acontece com todo mundo, né, não tem mais uma coisa que é exclusiva: "Não, isso aqui só acontece com homem", não tem muito disso... (Guilherme)

Os homens se preocupam mais às vezes com o desempenho sexual com uma mulher do que as mulheres, né? O homem se preocupa com ejaculação precoce, a mulher não tem isso, né, o homem pode ficar impotente, ele se preocupa com a mulher, né? O cara não pode subir mais e aí a mulher pode arrumar outro, então é uma situação que só acontece com os homens. (Glauber)

Ah, exame de próstata, por exemplo, isso só acontece com homem, é assim, um negócio que deixa encabulado um homem, mesmo porque mexe um pouco, assim, com o psicológico dele [...] (Eduardo)

Com essa fala, Eduardo levanta um debate que põe em questão a representação da sexualidade masculina: o exame do toque retal como prevenção do câncer de próstata. No Brasil, esse tipo de câncer é um problema crônico de saúde pública. Segundo o Instituto Nacional de Câncer (INCA), a alta incidência e a mortalidade dessa 
neoplasia fazem com que essa enfermidade seja a segunda mais comum entre os homens brasileiros (Gomes, 2003).

O exame de toque retal é uma medida preventiva de baixo custo, mas perturba tanto o imaginário de homens que os afasta da prevenção do câncer. Para Gomes (2003 p. 828), é relativamente fácil descobrir porque esse exame afeta tanto a identidade masculina:

Fazer o toque retal é uma prática que pode suscitar no homem o medo de ser tocado na sua parte "inferior" [...] O medo da dor, tanto física quanto simbólica, pode estar presente no imaginário masculino. $\mathrm{O}$ toque, que envolve penetração, pode ser lido como violação e isso quase sempre se associa a dor. Mesmo que o homem não sinta a dor, no mínimo, experimenta o desconforto físico e psicológico de estar sendo tocado, numa parte interdita.

A interdição de partes do corpo pode indicar que, culturalmente, há uma regulação do que pode e do que não deve ser permitido em relação ao contato corporal. $\mathrm{O}$ fato de ser penetrado pode fazer com que homens expressem resistências e constrangimentos, já que a imagem do masculino está ligada ao penetrador, ativo, e não ao penetrado, passivo; a condição passiva, desse modo, vai de encontro ao modelo vigente de masculinidade.

Outro medo masculino é que o toque retal possa ser interpretado pelo médico como indicativo de prazer. Ocorrida a excitação, indicada pela ereção do pênis, emerge o grande medo de que o médico pense que o homem esteja gostando de ser tocado, o que colocaria a sua masculinidade em xeque (GOMES; NASCIMENTO; REBELLO, ARAÚJO, 2008).

Ainda a respeito de situações masculinas, Marcos assinala que há situações que também podem acontecer com as mulheres, mas que o que as diferencia é que os homens criam condições e buscam que elas ocorram:

O cara vai e sai e consegue transar com duas mulheres ao mesmo tempo, isso pode acontecer com homem e com mulher, só que a mulher não procura, mas o homem procura.

Aluísio e Fábio ainda destacam que as mulheres de hoje estão muito parecidas com os homens, e como se sentem em relação a isso: 
O que pode ser só de homem? Não sei, eu acho que as mulheres hoje tão muito próximas dos homens, tá até chato, viu, elas tentam parecer muito com a gente... [...] A mulher hoje tenta sair em rodinha e ir no bar tomar cerveja, ficar falando dos homens como a gente sempre faz, como isso foi sempre característica do homem... Elas hoje querem independência financeira e ao mesmo tempo elas exigem um cuidado, assim, uma atenção [...]

E existem mulheres que tão nessa também, de chegar pros caras e falar que num momento de amor, ou de sexo, vai ser aquilo ali e não vai ser mais nada daquilo. E os caras se chocam, né, porque eles vêem o igual. E aí eu acho que é direitos iguais, tanto de homem quanto de mulher quanto a isso, pô, não dá pra ser machista nesse ponto. (Fábio)

O que se pode notar é que muitas vezes torna-se difícil para os jovens responderem sobre o que é exclusivo dos homens, uma vez que os papéis masculinos e femininos estão muito próximos e muitas vezes se confundem. Aluísio traz em seu discurso o aparente paradoxo entre uma mesma mulher que sai para beber cerveja com as amigas - um comportamento considerado tipicamente masculino - e quer ser cuidada pelo parceiro, o que pode indicar que ainda seja complicado para alguns homens realizarem a união da imagem de uma mulher que é independente e de uma mulher que também precisa de atenção e carinho.

\subsection{As melhores (e as piores) situações da vida de um homem}

Cara, parece bobo, mas uma coisa que é boa, assim, é a questão de direção, de dirigir carro, eu acho que é uma das melhores coisas pros homens, porque a maioria dos homens, desde a adolescência, já começa a aprender a dirigir o carro e mulheres, não. (Lucas)

[...] O meu padrinho, tio, madrinha, eles criavam situações em que eles duvidavam da minha masculinidade $e$, se bobear, eles duvidam até hoje, entendeu? Porque eles sempre me comparavam demais com o meu primo [...] Então sempre foram situações super constrangedoras, em que eu me senti um nada, sabe? (Aluísio) 
Para a maioria dos entrevistados, as melhores situações na vida de um homem estão relacionadas às conquistas pessoais, profissionais, materiais, afetivas ou sexuais, e também aos contextos masculinos, principalmente quando se está com os amigos:

Eu vejo as conquistas, né, de várias formas, as conquistas, conquistar alguma coisa, eu vejo como uma coisa bem, uma das coisas mais interessantes pra chegar em algum lugar, cê ter um objetivo e conseguir chegar. (Sérgio)

[...] A minha vida seria praticamente completa se eu tivesse todos os meus brinquedos [...] um quadriciclo que eu já tenho, meu jet-ski que é um sonho que eu vou realizar ainda, são brinquedos mesmo, são coisas que... O meu carro, eu tenho, mas não é ainda o que eu quero, mas eu vou chegar lá, minha casa com o meu próprio playground, que significa churrasqueira, piscina [...] (Guilherme)

Ah, cara, eu acho que a gente tem muito guardado emotivamente as transas que a gente já teve. Assim, por exemplo: eu fecho os olhos assim, inconscientemente eu fico lembrando de umas. São transas inusitadas, em lugares $\mathrm{X}, \mathrm{Y}$, que acontecem, eu acho que isso tem valor pra gente (Fábio)

A gente fez um ménage, tipo, eu, ela e uma amiga dela, porque eu queria fazer, o caralho, tal, ela topou e a gente fez. (Bernardo)

Sabe uma coisa que é muito boa? Eu acho que sair com amigo, tomar cerveja, sem mulher nenhuma. Eu acho que isso é necessário pra todo mundo. (Marcos)

As piores situações para um homem, segundo os participantes, estão ligadas a fracassos pessoais e profissionais, a dificuldades em relacionamentos e que também trazem à tona a imagem de perda da virilidade masculina, de traição e de impotência sexual:

Puta, a pior situação pra um homem é ter que terminar com a menina. Porque geralmente quem termina é o homem, raras vezes a mulher termina com o cara [...] Terminar pra mim é um processo muito, muito, muito, longo, tipo, quando eu digo muito longo é que não é de semana ou mês, é coisa que se arrasta, às vezes, seis meses pra conseguir terminar com alguém. (Bernardo)

Frustração, é você não conseguir atingir seu objetivo, é você ter que se reerguer de novo. Ansiedade eu também vejo como uma situação bem horrível. (Sérgio)

Eu acho que é não ter recurso, às vezes, eu acho que é ficar sem grana, pra gente é horrível ficar em grana. (Fábio) 
Não conseguir uma profissão legal, ser descontente com isso, ser infeliz com isso, ter sempre um monte de dívida porque não tem um trabalho legal, entendeu? Conhecer a pessoa errada, a mulher errada, ser traído, ou ser impotente, né, ter um filho doente [...] Não conseguir realizar os seus sonhos. (Glauber)

Broxar, né? Tem pior que isso? E isso não inclui a mulher, é só o cara mesmo. Se o cara não dá conta, a mulher não perdoa, né? A não ser que for sua namorada, sua esposa, sua noiva. Se você tá com uma outra mulher, cê vai achando que vai dar certo, chega lá e cê broxa, a mulher vai te zoar pro resto da sua vida. Aquilo lá é inesquecível. (Marcos)

[...] As piores situações que podem acontecer na vida de um homem é ele ser traído, pra mim, na minha opinião, principalmente se ele vê a traição. (Lucas)

Nas respostas acima emerge novamente o modelo ideal de masculinidade e, quando não se consegue cumpri-lo a contento, as consequências são frustração e sofrimento:

Ser forte, confiante, ativo, destemido, determinado, realizador, independente, objetivo, pragmático, racional, emocionalmente equilibrado, profissionalmente competente, financeiramente bem sucedido e sexualmente impositivo são algumas das descrições pertinentes a um modelo ideal de masculinidade (WANG; JABLONSKI; MAGALHÃES, 2006, p.56)

Percebe-se, desse modo, a força que os estereótipos de gênero ainda possuem no cotidiano desses homens inseridos no mundo contemporâneo, em que valores e identidades são tão voláteis e provisórios. O modelo patriarcal de homem ideal pode ser visualizado aí mais uma vez, especialmente na ênfase sobre o desempenho profissional e sexual.

Esse modelo acaba limitando as possibilidades de realização masculina, uma vez que se encontra relacionado principalmente à esfera do trabalho, ao acúmulo de bens e à vida sexual tão diversificada e intensa quanto possível. Desempenho profissional ou sexual pouco satisfatórios são fracassos de difícil elaboração e em alguns casos, o homem pode buscar na violência um meio de defesa contra seus sentimentos de inferioridade e frustração. (WANG, 2004) 


\subsection{Inadequado?! Eu?!}

Outra questão colocada aos participantes foi se eles já haviam vivenciado alguma situação em que se sentiram inadequados enquanto homens. A grande maioria afirma nunca ter experienciado tal situação, alguns dizem não se lembrar. Leandro diz que já passou por situações em que falou demais o que não deveria e se sentiu totalmente inadequado e também coloca o início de namoro na adolescência como um momento em que muitas vezes não sabia como agir:

Acho que no começo mais era ter uma idéia de ser tímido, cara, acho que era algo mais... De você não saber, vamo dizer, ter essa timidez de, dependendo, porra, essa menina beija todo mundo, vai lá, ela quer te beijar! E cê não saber realmente o que faz, cara, entendeu?

É necessário observar que, apesar de muitos entrevistados não afirmarem diretamente o seu sentimento de inadequação, os jovens também trazem ao longo das entrevistas momentos em que se sentiram em dificuldades por serem como são e situações constrangedoras diante de homens e mulheres. Bernardo e Glauber chegam a descrever a mesma situação: a possibilidade de ter que ficar nu na frente de outros homens. A nudez, como pode ser apreendida em depoimentos a seguir, não significa apenas a exposição do corpo; mais importante do que isso é o desnudamento psicológico, da interioridade, da subjetividade, daquilo que não se deseja revelar e tornar público.

Ah, cê xavecar uma mulher, por exemplo, seus amigos só olhando "Ah, ele vai conseguir, ele vai conseguir", a menina fala não, aí você fica constrangido. Receber um fora de uma menina muito feia na frente dos seus amigos também, você vai ficar muito constrangido... (Eduardo)

Quando eu era mais novo, como eu sempre joguei bola, quando eu era mais novo, eu jogava num time, que eu peguei reserva. E pra mim, isso foi super constrangedor, porque na época eu era... Eu achava que eu jogava mais do que os outros, né? (Marcos)

Ah, meu, eu não gosto de ficar pelado e aí, tipo, aqueles bagulho de exército, que fica todo mundo, tipo... Nossa, aquilo é uma merda, cara! Eu não cheguei a ter que ficar pelado, mas eu tive que ficar de cueca, mas, puta, eu não gosto, me incomoda, cara. Me incomoda bastante, eu sou bastante reservado (Bernardo) 
É aquele negócio, que nem quando eu fiz Tiro de Guerra, mas eu acho que a maioria dos homens fica, né? Porque é aquele negócio, o cara vai lá e fala: "Ih, cara, cê vai ter que tirar a calça lá na frente de um monte de soldado lá pra fazer o exame do coisa...", né? [...] "Mas que foda, hein, ter que tirar a calça lá, ficar... né, na frente dos cara pros cara fazer exame, tal" (Glauber)

Aluísio é quem revela mais diretamente o seu sentimento de inadequação diante de certas ocasiões no contato com as mulheres:

[...] Sabe quando eu me sinto inadequado enquanto homem? Quando, às vezes, eu tô perto de uma mulher muito bonita, eu tenho a autoestima baixa e eu não sei o que falar [...] Aí, naquela hora eu não consigo ser homem, entendeu? Naquela hora, às vezes, eu acabe falando coisas nada a ver, eu me sinto o último ser humano na face da terra.

Aluísio ainda ressalta que é muito difícil se aproximar de mulheres que "se impõem”, ou seja, que são muito ricas, muito bonitas ou muito instruídas. No caso de mulheres instruídas, por exemplo, como ele estudou em uma universidade pública de qualidade, afirma que consegue lidar bem com uma mulher inteligente, já que utiliza a sua graduação como uma "muleta”. Entretanto, quando essa “muleta” não serve para outras situações, Aluísio afirma que realmente não consegue ser homem:

Eu me sinto muito perdido e a mulher vira um monstro perto de mim. Então, nessas situações de flerte mesmo, de paquerar, nessas situações de paquerar, aí eu não consigo ser homem.

Ao tratar das mulheres belas e atraentes, Gikovate (2004, p.124) assinala que essas são as causam maior sensação de inferioridade nos homens. E, se também forem inteligentes, cultas, de caráter, o homem se sente mais apavorado ainda e não consegue se sentir à altura delas. $\mathrm{O}$ autor citado acima também afirma que há uma tendência em muitos rapazes de se unirem a mulheres que não estão no mesmo nível intelectual e moral que eles, uma vez que

Quando existe igualdade de condições, eles se sentem por baixo devido ao fato de desejarem com mais intensidade do que se sentem desejados. Os homens se sentem dessa forma independentemente do que se passa na mente feminina. Não se trata de quanto a mulher deseja o homem e sim de quanto o homem se sente desejado.

Fábio, por sua vez, traz o seu sentimento por ter sido traído pela ex-namorada: 
Eu me senti inadequado quando eu já tive momento de traição, eu já fui traído, então... Cê fala: "Tava tudo lindo, porra! A mina foi lá e... Putz, o que eu fiz de errado?" Isso você se sente muito inadequado, entendeu, você fica sem chão, você tem o trabalho, você tem dinheiro, mas... Aí, então, isso é pior do que não ter dinheiro, porque mesmo com o dinheiro, você se sente o cara mais corno do mundo.

\subsection{As delícias e as dificuldades da relação entre homens $e$ mulheres}

\begin{abstract}
Outro dia eu tava até brincando, né, apareceu na TV comida japonesa, e ela: "Hummmm...", enquanto assistia TV, né? Ai depois de uns 20 minutos, ela: "A gente precisava sair um pouquinho, né, ir comer alguma coisa". Aí eu: "É, a gente pode fazer isso depois. Onde cê quer ir?" Ela: "Sei lá, um lugar que eu goste". Eu: "Como eu vou saber o lugar que cê gosta?" Aí eu virei pra ela: "Por que você não fala direto que você quer ir comer comida japonesa que eu pego o carro e a gente vai comer comida japonesa?" (Guilherme)

O homem é uma pessoa mais dada, assim, o homem é uma pessoa que tá mais aberta a se relacionar com outras pessoas, amigos, até amigas, mesmo, ou até no caso de jogo de sedução, alguma festa, uma pessoa que tá mais aberta a se relacionar do que a mulher. A mulher, geralmente, ela fica mais resguardada, mais na dela. (Lucas)
\end{abstract}

A mulher é o termômetro, eu acho, é ela que decide se vai rolar ou não (Marcos)

Perguntados acerca da diferença entre homens e mulheres, os participantes apontam como a principal diferença o lado racional, característico dos homens, em contraposição ao lado emocional feminino. Aluísio e Guilherme pontuam que os homens são mais impulsivos em suas atitudes do que as mulheres:

Eu acho que o homem, ele é bem mais racional que uma mulher, ele consegue ser mais prático em tudo, nas coisas, no trabalho, até nas relações... [...] É mais explosivo [...] É confuso pra mim, mas eu acho que, assim, socialmente homens e mulheres são muito próximos. [...] Eu vejo mais as diferenças mais nesse aspecto, de personalidade, de o homem ser mais prático e a mulher mais enrolada, o homem saber 
mais o que quer, ou achar que sabe o que quer e a mulher ser mais indecisa, o homem tomar as decisões $\operatorname{logo}$ e a mulher ficar mais confusa. (Aluísio)

Eu acho que a mulher tem mais responsabilidade do que o homem, assim, o homem trabalha, ganha o dinheiro dele, se ele quer alguma coisa, ele paga por aquilo. A mulher não, a mulher, além disso, ela tem que ter responsabilidade de, se ela engravidar, com outra vida, então assim, a responsabilidade da mulher é maior. [...] $\mathrm{O}$ que diferencia o homem da mulher é que elas têm mais capacidade, mais força, mais possibilidade que o homem. E é o que vem acontecendo, né? (Eduardo)

O homem é esse cara que vai pensar mais com a razão, a mulher é mais com a emoção. Só que assim: o homem vai ver detalhes que a mulher não vê, só que a mulher vai ver coisas que o homem não tem nem condição de ver. A mulher consegue observar o todo em detalhes e o homem, ele enxerga no horizonte: "Ah, é aqui". Então a mulher ela leva pra um lado mais emocional, equilibra o relacionamento com o homem, né? Então é ela que amamenta, é ela que tem a força pra ter o parto, é ela que procria, é ela que cuida do ninho, né? (Glauber)

Eu acredito que a mulher é muito mais forte do que o homem, vamos dizer assim, generalizando, quem é mais forte, homem ou mulher? Mulher, cem vezes mais forte, tem uma garra, um quê a mais. Depois que você acompanha alguém da sua família muito próximo ter filho também, cê fala: "Brincadeira o que essa mulher faz!" (Leandro)

Fábio ressalta a diferença entre o lado público, ligado ao domínio masculino, em contraposição ao lado doméstico e do cuidado dos filhos, ligado ao universo feminino:

A relação com o corpo dela mostra o que ela é, a mulher, ela precisa premeditar mais, ela precisa se programar mais, ela precisa fazer planos. Porque ela se preocupa com a cria. Ela é pra dentro, né? Vai nascer alguma coisa lá dentro dela, ela vai ter que proteger aquilo e ela não pode caçar, ela não pode pescar, ela não pode ficar o tempo todo lavrando. [...] O homem é pra fora, entendeu?

\subsubsection{A objetividade masculina $x$ os "rodeios" femininos}

Guilherme assinala que uma diferença fundamental entre homens e mulheres é a objetividade masculina contrastando com o "fazer rodeios" feminino:

Se eu tenho uma coisa contra você, eu vou chegar pra você e falar: "Olha, eu tenho tudo contra você. E não vou falar com você, não vou 
querer papo com você, não vou querer nada com você, entendeu?" Eu vou falar: "Não chega perto de mim, senão eu vou te dar uma bolacha!" A mulher não, a mulher, ela faz rodeio com as pessoas, ela não tem essa coragem de bater de frente.

O que parece ser comum nas respostas de alguns dos jovens, ao assinalarem as diferenças entre homens e mulheres, é que o fato de os homens, em geral, dizerem o que sentem em relação ao outro faz com que eles guardem menos rancor das relações fracassadas. As mulheres, por não se comportarem dessa forma e não demonstrarem seus sentimentos acabam entrando naquilo que Lucas chama de "jogo meio falso":

[...] A mulher às vezes ela odeia uma mulher, só que ela vai lá, cumprimenta, faz aquele jogo meio falso. O homem não, se o cara não gosta do cara, ele não vai lá, não fala e às vezes faz até questão de demonstrar que não gosta do outro cara.

[As mulheres] defendem mais, elas guardam mais, elas acham que... Eu acho que a mudança pra mulher é muito mais drástica do que pro homem, eu acho. Como elas são ligadas mais a emoção, então a emotividade delas não deixa elas esquecerem do passado com mais facilidade do que os homens. (Glauber)

Guilherme utiliza uma estória para expor essa diferença dos comportamentos masculinos e femininos:

O homem, por natureza, ele se sente mais agressivo, aí ele chega, por exemplo: um homem chega em outro homem: "E aí, seu filho da puta, seu desgraçado, como vai? E aquela piranha que cê namora?", já chega chutando o balde, né? Aí vira as costas e fala: "Aquele cara é gente boa pra caralho, né?" Aí quando chegam duas mulheres pra conversar: "Oh, que cabelo lindo, que coisa maravilhosa! Onde você cortou?" Quando vira as costas: "Nossa, que baranga! Onde ela cortou aquele cabelo?"

Fábio, entretanto, é o único dos entrevistados que diz que os "rodeios" também fazem parte do mundo masculino:

[...] O homem é nômade por natureza, cara, entendeu? Agora, o homem, eu acho que ele erra quando ele não fala isso pra mulher declaradamente, quando ele fica tendo que dar voltas pra poder viver uma relação. Ele tem que chegar e expor o que acontece. 


\subsection{2. É a mulher quem decide? A mulher atual, pela voz deles}

Outro ponto levantado por Eduardo, Glauber, Marcos e Guilherme refere-se ao poder de escolha da mulher na paquera. Todos afirmam que, em última instância, é a mulher quem decide se algo pode acontecer entre os envolvidos ou não:

Como [a mulher] conquistou a liberdade, ela tem a possibilidade de ficar com quem ela quiser, da forma que ela quiser, a mulher que controla isso, se ela vai pra cama ou não com o homem, é ela. Não é o homem que vai pra cama com uma mulher, é a mulher que vai pra cama com o homem. [...] Se ela falar não, é não e acabou! Se ela fala sim, é sim e vão os dois. (Eduardo)

[...] O homem, ele não escolhe o que ele quer. Ele vai lá, ele tá numa balada, tem um monte de menina, ele pega qualquer uma. Se apareceu pra ele, se for pra pegar todas, ele pega todas. Com a mulher, não, a mulher vai pegar aquele que ela quer, ela escolhe. (Glauber)

Pra mulher, por exemplo, a mulher, se ela for bonita, tal, se ela chega numa balada e ela quer ficar com alguém, ela fica com quem ela quiser. O homem já não é assim, por mais bonito que o cara seja, se ele chegar, é ele que vai ter que ir atrás, é ele que vai ter que conseguir alguma coisa. Agora a mulher não, a mulher chegou, se o cara chega nela e ela quiser, ela fica, né? (Marcos)

A escolha do parceiro normalmente recai sobre a mulher, é ela que escolhe, a gente hoje tem que batalhar bastante pra conseguir a parceira que quer, entendeu? A mulher tem mais facilidade, é só apontar e falar: "Eu quero aquele ali", já é bem mais simples. Apesar de ter menos homens no mundo, eu não entendo isso! (risos) Se pela lei de oferta e de demanda, era pra ser o contrário, né, a gente que deveria escolher, né? (Guilherme)

As falas acima subvertem os estereótipos masculinos e femininos, expressando o poder da mulher sobre suas escolhas e o destino dos parceiros. evolução que as mulheres tiveram, foi o fato de elas serem muito mais conscientes de se firmarem profissionalmente primeiro e depois 
sim, vir a constituir uma família, se firmarem sentimentalmente, com um relacionamento com outra pessoa. (Lucas)

Eu acho que talvez, um dia, o homem e a mulher sejam iguais. Mas hoje em dia não são [...] A sociedade é assim, ela vem mudando, mas a mudança é muito devagar e a mulher tá passando a ter os mesmos direitos de um homem. Hoje em dia cê vê na balada, por exemplo, uma mina chegar, te agarrar e querer te beijar, que é uma coisa que eu não sei, mas, porra, há cinco anos atrás eu não via isso acontecer. Então eu vejo que elas tão se liberando, que elas tão, tipo, indo atrás do direito que elas deveriam ter. (Bernardo)

Segundo Goldenberg (2001), não é muito claro o que é considerado norma ou desvio no que se refere aos modelos de masculinidade e feminilidade atuais. Para a autora acima, nunca homens e mulheres foram tão parecidos em atitudes, valores e desejos como o são hoje, ainda que existam muitas diferenças entre eles, especialmente no espaço privado.

Uma argumentação que talvez ajude a explicar a dificuldade na convivência entre homens e mulheres reporta-se à maior autonomia e independência femininas, fruto da inserção da mulher no mercado de trabalho. E é evidente que todas essas transformações têm suas repercussões na vida dos homens, na forma como se dão os relacionamentos e na convivência entre homens e mulheres. Os jovens entrevistados também se posicionaram a respeito da imagem que têm da mulher atual e também refletem o panorama de transformações vivenciadas pelas mulheres:

[...] Tem vários tipos de mulher: tem mulher puta, galinha [...] vai chegar aos 40 anos perdidaça, dando pra todo mundo. E essas, às vezes, servem pra gente bem, quando cê só quer isso. Tem as mulheres que são as perfeitinhas, bonitinhas, que servem pra você trazer em casa, apresentar pro pai e pra família [...] Só que essas daí são entediantes [...] E tem as do meio, eu acho que eu tenho que encontrar uma do meio. (Aluísio)

A fala de Aluísio ilustra alguns modelos de mulher ainda presentes na sociedade brasileira: o modelo da mulher "esposa-mãe", nomeada por ele próprio como "Amélia" (em referência à canção composta por Ataulpho Alves e Mário Lago) e o modelo da mulher mais independente e liberada sexualmente. Nas próprias palavras do 
entrevistado, parece difícil encontrar uma mulher que possua ambos os atributos, que trabalhe e que também seja voltada ao espaço doméstico. Aluísio ainda pontua que deseja encontrar uma mulher que seja "uma dama de dia e uma puta de noite".

A última vez que uma menina tentou me agarrar, tipo, era um menina feia, eu não queria beijar ela, dei uma puta desculpa, eu me senti uma mulher, tá ligado? Eu dei uma desculpa: "Não, moça, eu não posso te beijar, eu tenho namorada e a minha namorada tá aqui na festa". E era mentira, é aquilo que a gente ouve as minas falando pra gente quando a gente chega nelas, então, eu achei engraçado isso, elas tão realmente empatando o jogo, tão alcançando a gente. (Bernardo)

Ainda se nota nos discursos de alguns entrevistados a coexistência entre esses modelos de mulher, mas todos são unânimes em reconhecer o quanto as mulheres alcançaram seus direitos e sua auto-suficiência, ainda que alguns dos jovens afirmem que elas não saibam o que fazer com todas as suas conquistas:

Cara, eu acho que elas tão crescendo, eu vejo elas como tipo uma criancinha pequena, o universo feminino como... Sei lá, uma préadolescente, assim. Elas já sabem o que elas querem, elas só não têm coragem de fazer tudo que elas querem. Eu acho legal, eu acho bonito. (Bernardo)

Cara, eu acho que as mulheres são mais feministas do que os homens [...] Tem determinadas coisas, determinadas leis [...] que elas querem ter o mesmo direito que os homens. Na hora que chega pra realmente pra acontecer, elas pulam pra trás: “Ah, não, mas isso é negócio de homem!" [...] Como elas subiram rápido demais, elas não tiveram noção ainda do que é realmente ter isso na mão delas [...] (Glauber)

[...] Elas têm uma busca por um padrão de beleza físico, elas buscam também um homem que tenha um perfil financeiro superior, ou no mínimo igual a elas, né?[...] Mas por outro lado também tem mulheres que se interessam também pela qualidade do homem, a qualidade de conversa, a qualidade [...] (Sérgio)

Lucas, Fábio e Marcos levantam uma temática bastante presente no cotidiano masculino: as condições desejadas para se estabelecer um relacionamento afetivo, em uma época em que a mulher está mais liberada sexualmente:

[...] Hoje eu vejo que as mulheres, pelo fato de elas se tornarem muito mais independentes, elas são muito mais precavidas de um relacionamento do que antes. Antes a mulher era muito mais preocupada em ter um namorado pra constituir família e casar do que hoje. Hoje não, as mulheres são muito mais independentes, você vê 
muitas mulheres com 30 anos solteiras, indo pra festa, ficando com outros... (Lucas)

Elas tão mais objetivas, elas sabem o que elas querem, elas são autosuficientes, graças a Deus, que bom! E elas tão tendo as experiências delas igual nos já tivemos várias das nossas, se relacionando com vários homens, várias condições desses homens, elas tão mapeando. Igual a gente mapeia pra chegar no objetivo final, que é de repente, de repente, ter uma mulher só. Elas tão na mesma, na mesma coisa (Fábio)

A mulherada tá doida, né? Eu acho que o que os outros falam é verdade, acho que deve tá faltando homem, não é possível, porque tem mulher fazendo umas coisas meio absurdas, né? A mulher não tem mais censura pra nada, ela vai e pega o cara na frente de todo mundo, depois fica com outro na frente de todo mundo, sabe? (Marcos)

O que se nota nas falas dos jovens, e que também é analisado por Goldenberg (2001) é que as mulheres passaram a fazer maiores exigências em seus relacionamentos afetivos e sexuais, escolhendo também que tipo de relação querem vivenciar com seus companheiros. Não querem mais casar a qualquer preço, preferem viver sozinhas a enfrentar uma relação que não as satisfaça, têm mais medo da solidão vivida a dois do que a falta de um parceiro amoroso. Podem ter relacionamentos esporádicos com frequência e também "ficar” com vários parceiros ao mesmo tempo, o que já as torna, na visão masculina, uma “biscate”, como afirmam alguns sujeitos.

E, nesse sentido, é possível constatar que homens e mulheres mudaram substancialmente nos últimos anos, mas ainda muitos estereótipos permanecem no imaginário social. Alguns dos entrevistados argumentam que acham injusto o fato de o homem que tem várias aventuras sexuais ser considerado um garanhão, o que é considerado simbolicamente positivo no universo masculino, ao passo que a mulher que faz o mesmo é taxada de "puta" ou "biscate" pelo conjunto da sociedade.

De fato, argumentam que ambos deveriam ter os mesmos direitos no plano do relacionamento sexual e que não deveriam ser qualificados em função de critérios moralizantes.

Entretanto, ao se referirem às mulheres que têm vários parceiros sexuais, suas falas as denominam da mesma forma pejorativa, o que demonstra que a dupla moral sexual ainda esta muito presente nos discursos dos entrevistados, como se vê na fala de Marcos e Bernardo:

A sociedade que é machista, né, que fez virar isso. Eu acho que todo mundo tem direito igual, né, se o homem pode, por que a mulher não 
pode? Eu acho que a nossa cabeça, ela já tá feita pra isso, se a gente vê uma mulher fazendo isso, todo mundo vai pensar isso, eu vou acabar pensando isso justamente por causa da sociedade. Mas eu acho que é errado. (Marcos)

[...] O homem não tem limite, né, cara? Se eu ficar com uma menina hoje, outra amanhã e for viajar pra casa de uma amiga no final de semana, algumas pessoas vão achar isso do caralho, outras vão achar que eu sou besta, mas ninguém vai achar, tipo, que eu sou galinha, ou que eu sou piranha, ou que eu não posso fazer isso. Então isso é uma coisa que eu acho vantagem. (Bernardo)

Essa permanência de valores antigos convive lado a lado com uma nova condição, onde os papéis masculinos e femininos já não se delimitam de modo claro e preciso, evidenciando a dificuldade no relacionamento com as mulheres e nas representações que ainda estão associadas ao sexo feminino.

\subsubsection{O "ficar"}

Dentre as novas formas de relacionamento amoroso, especialmente no que diz respeito aos adolescentes, o chamado "ficar" é uma modalidade de relação que vem se tornando cada vez mais comum a partir da década de 1980. Por ser relativamente recente, o "ficar" ainda não foi totalmente compreendido como outras formas de relacionamento tradicionais, como o namoro, o noivado e o casamento.

O "ficar" tem como base fundamental a ausência de compromisso entre os envolvidos, que visam à obtenção de prazer, por meio do exercício da sedução. $O$ envolvimento pode se dar desde uma simples troca de beijos e abraços até a ocorrência de uma relação sexual. Há nessa modalidade de relação um espaço para a intimidade, entretanto, ao mesmo tempo nota-se um relativo afastamento entre os parceiros.

Segundo Chaves (2001), o "ficar" tem sua razão de ser na sociedade contemporânea na medida em que o que o importante é a auto-satisfação e a evitação da frustração que poderiam ocorrer dentro de um compromisso com o outro. Desse modo, nega-se a alteridade, em troca de objetivos narcísicos, em que o outro se torna “descartável”, substituível, se não corresponder a determinadas expectativas.

Ao se posicionarem a respeito do "ficar", os entrevistados afirmaram que esse tipo de relacionamento pode ser benéfico para um maior conhecimento do outro e, a partir dessa convivência, pode ocorrer o aprofundamento da relação, como o 
estabelecimento de um namoro. Também argumentam que compartilham da visão de que o "ficar" é algo transitório e passageiro, onde não há compromisso entre os envolvidos; nesse sentido, pontuam que ser o "pegador", ou seja, "ficar" com muitas mulheres é algo valorizado, mas que a partir dessa postura não se constrói uma relação consistente com ninguém:

Antigamente as famílias eram meio que encomendadas, né, você não tinha um jeito de conhecer outras pessoas, era uma família com a outra e acabavam casando pessoas que não se gostavam ou acabavam se gostando no decorrer da vida. O ficar eu acho que é uma arma aí hoje, é uma arma pra gente conhecer as pessoas [...] (Glauber)

Aí esse ano meio que... Putz, foi muito diferente, eu já beijei, sei lá, umas quatro mulheres e eu sou muito tímido, entendeu? Já transei com duas, não tô mais ligando se, tipo... Porque eu saí com fulana, se eu vou namorar ou não. Porque antes eu achava assim: "Não, eu vou namorar e eu vou casar!", sabe, achava que eu tinha que arranjar uma mulher que eu começasse a namorar, que ia vir na minha casa, que ia casar... Eu tinha um desespero por causa disso e isso inviabilizava qualquer relação. (Aluísio)

Eu acho que é uma putaria que eu adoro, é uma putaria maravilhosa, mas eu acho um absurdo, eu acho que é uma coisa que não deveria existir, mas se a regra é essa a gente aproveita. (Bernardo)

Eu acho que é bacana, é fundamental, principalmente pra conhecer outras pessoas, pra se destacar na sociedade, assim...com relação a namoro... Destacar não, pra crescer, pra você amadurecer, é importante. (Eduardo)

Dentro dessa temática, emergem mais uma vez os estereótipos contemporâneos de homens e mulheres mais liberados sexualmente e suas relações fluidas. Entretanto, dentro do próprio "ficar" torna-se difícil delimitar os espaços e as responsabilidades de cada parceiro. Esse aspecto fica mais claro na fala de Leandro, ao tratar de a relação com uma "ex-ficante":

[...] Aí é aquela situação chata, eu fui xavecar outra mulher e... Falei: "Eu não sou nada, eu não tenho que te dar satisfação", e uma conhecia a outra e uma foi falar pra outra, meio que "Ah, tá vendo, cê ficou, mas ele queria eu", uns papos... Falei: "Eu não tenho que dar satisfação nenhuma", liguei pra outra: "Desculpa se eu te chateei" [...] [Ela disse]: "Pô, achei que tivesse rolando alguma coisa legal". Eu falei: "Ó, infelizmente, às vezes tá rolando pra você, mas pra mim não tá" $[\ldots]$ 
Percebe-se por essa fala que o "ficar" envolve certa intimidade entre os indivíduos, mas também traz consigo um afastamento, em que comportamentos, desejos e expectativas não são convergentes, já que muitas vezes os limites do relacionamento não são estabelecidas entre os parceiros.

Mais uma vez as condições para a continuidade da relação são levantadas pelos participantes, como se visualiza na fala de Leandro:

Eu acho que é uma maneira de conhecer, só que lógico, é aquele ponto, é uma maneira de conhecer assim, se você fica com uma menina, beija ela, já sai, já transa com ela, pra mim, sinceramente, a não ser que ela seja o amor da minha vida e Deus falou: "É ela", né, eu nunca mais vou sair com ela, dificilmente eu vou sair com ela de novo, ou vou sair só com essas intenções, de sair e fazer o que for.

Para a maioria dos entrevistados, o "ficar" não foi considerado como o tipo de relacionamento favorito, pois, ainda que envolva muita sedução e prazer, a ausência da exigência de compromisso não traz as vantagens de um namoro, como a cumplicidade e a profundidade da convivência. Esse ponto vai ao encontro da pesquisa de Justo (2005), que afirma que o "ficar", apesar de ser conhecido como uma forma de relação adolescente, não é enxergado como o relacionamento desejado, aquele em que o jovem gostaria de viver ao longo da vida.

\subsubsection{O namoro}

Dos dez homens entrevistados, cinco tinham namoradas (Eduardo, Glauber, Lucas, Marcos e Guilherme) e cinco estavam sozinhos (Aluísio, Bernardo, Leandro, Sérgio e Fábio) na época da realização da entrevista. Todos eles, inclusive aqueles que afirmaram estar sozinhos, já haviam namorado pelo menos uma vez. E todos os cinco jovens que namoravam não estavam em seu primeiro relacionamento.

Os participantes relataram como foi e é vivenciar a experiência do namoro, contando inclusive como foi o início de relacionamentos:

Ah, cara, foi uma merda, porque foi assim: eu nunca transei com ela, aliás... Eu namorei a Sophia quando eu tinha 24 anos e, aliás, eu era virgem com uma mulher. Porque, pra falar a verdade, eu não dava conta de transar com uma mulher, sabe? Não tinha vontade de ir na zona, sei lá... Eu fui perder a virgindade [...] Esse ano, entendeu, aos 26 anos. Depois disso, eu melhorei bastante, sabe, eu me senti mais homem. (Aluísio) 
Aí um dia eu encontrei com ela no trabalho, numa agência de publicidade, peguei o telefone dela, também sem maldade nenhuma, por amizade, só que um dia me deu uma coisa, né? Falei assim: "Vou ligar pra ela, tô solteiro, tal, vou sair". Aí convidei ela pra sair, aí acabou rolando, foi meio que natural, assim. (Glauber)

O máximo, máximo, máximo foram três, quatro anos. Assim, eu sou muito acelerado, digamos assim, se tivesse um gráfico aí de envolvimento versus tempo, eu começo muito acelerado, depois eu começo... Depois esse gráfico, ele faz uma montanha russa. Então é difícil, eu gosto muito de tá apaixonado, então cê trabalha muito com a parte de paixão, com a parte de envolvimento forte, assim. Tirando isso, aí complica um pouco. (Sérgio)

Eu conheci ela numa festa da igreja, eu bati olho... Eu nunca tinha visto, eu conheci, o meu cunhado conhecia ela, aí eu conversei com o meu cunhado pro meu cunhado ir conversar com ela pra mim, né? E aí, nossa, naquele dia nem rolou nada, nem conversei com ela aquele dia. Mas aí ela tinha me visto também, tinha se interessado por mim, aí acabei combinando de conversar com ela. E até a gente começar a ficar foi um mês conversando, isso porque eu imaginei que fosse dar no que deu mesmo, né? Então demorou um mês pra gente acabar ficando, né? Mais ou menos por aí. (Marcos)

Os jovens afirmam que alguns fatores são fundamentais para um bom relacionamento, como confiança, diálogo, respeito e cumplicidade. Entretanto, parece ficar claro que a maioria dos entrevistados concebe que um relacionamento satisfatório não envolve pessoas com interesses e gostos muito discrepantes; afirmam não dar muito crédito ao ditado "Os opostos se atraem". Em vez disso, eles elegeram como imprescindível a afinidade entre os parceiros e, inclusive, a afinidade sexual:

Agora fundamental mesmo é você tá na mesma sintonia, no mesmo objetivo de vida, entendeu, querer a mesma coisa, constituir família, por exemplo. Acho que isso é fundamental, querer tá junto com a pessoa. (Eduardo)

Eu acho que tem que ser lealdade, verdade, cê tem que contar a verdade, falar o que realmente sente, tentar manter a harmonia sempre... (Glauber)

Ah, confiança, cara, eu acho que você tem que ter afinidade com a pessoa, não adianta... $\mathrm{E}$ afinidade vem de entendimento de pensamento... (Leandro)

Respeito, envolvimento... Tem que ter interesses em comum, eu não acho que opostos se atraem, eu não sou dessa linha, eu acho que opostos se repelem totalmente. Confiança, e sempre ter paixão, cê tem que ter... (Sérgio) 
Cara, sem hipocrisias, é fundamental a afinidade sexual, química, né, honestidade é fundamental, e respeito. Eu acho que são os três fatores fundamentais pra um namoro dar certo. (Lucas)

As vantagens de um relacionamento afetivo repousam principalmente sobre ter uma parceira que seja companheira para todos os momentos da vida e com ela dividir o cotidiano e suas alegrias, problemas, dificuldades, planos e sonhos. É a possibilidade de estabelecer um relacionamento de maior intimidade e profundidade, que envolva compartilhar opiniões, ideias, sentimentos, de se sentir ouvido e acolhido:

Mais a cumplicidade e o fato de um poder ajudar o outro, acho que ajudar em tudo, desde a casa até escutar, ouvir, o positivo eu acho que é isso. (Eduardo)

Agora é bom, porque você tem uma pessoa, um porto seguro pra poder te dar opiniões importantes, entendeu, opiniões maduras sobre o que você deve fazer, ela ajuda você às vezes a se concentrar, focar no seu trabalho, ajuda você a manter a seriedade, a imparcialidade, me ajuda, principalmente. (Lucas)

A afinidade entre os parceiros, citada especialmente por Eduardo, Bernardo, Sérgio e Guilherme, quando se dá, é eleita como uma das maiores vantagens do relacionamento. Abre-se espaço também para a ampliação da capacidade de entendimento entre os companheiros e também aparece a comunicação não-verbal, por meio de expressões corporais como olhares e gestos executados entre ou para os parceiros, em determinadas situações. Tais expressões demonstradas, segundo Guilherme e Marcos, teriam o mesmo significado para ambos os namorados e seriam compreendidas pelo interlocutor sem que fosse necessária sua explicação verbal:

E eu acho que não é só no sentido da conversa falada, eu acho que muitas vezes o casal chega ao ponto [...] de conversar sem precisar falar uma palavra, entendeu? Eu vejo isso com a minha namorada atual [...] você conseguir, só de olhar pra cara da outra pessoa, ela saber tudo o que você tá pensando. (Guilherme)

[...] Eu acho que o ponto mais positivo é que ela, quando eu penso, ela sabe o que eu tô pensando, e quando ela pensa, eu sei o que ela tá pensando, tem uma sintonia muito boa. (Marcos)

Outro aspecto bastante valorizado pelos entrevistados quando se referem ao namoro é a postura da parceira frente à independência deles em alguns espaços da sua vida. É quase que unânime a condição do respeito ao espaço privado masculino, sem a 
presença ou interferência feminina, para a continuidade da relação. Nesse sentido, um ponto levantado por alguns entrevistados está intimamente ligado a como a namorada se porta frente à amizade deles com os amigos do sexo masculino.

Alguns dos participantes ponderam que em certas situações, eles têm de abrir mão de um contato maior com os amigos para preservar o namoro e que nesse sentido a relação de amizade é afetada.

Os depoimentos dos jovens demarcam que a amizade com os amigos e o namoro são esferas separadas - ainda que estejam sobrepostas por vezes, o que por si não é algo negativo - porém o espaço de convivência exclusiva com os pares do mesmo sexo é fundamental em suas vidas cotidianas. E que uma relação em que o contato estabelecido com os amigos não é fonte de problemas para o namoro traz muita tranquilidade a eles:

São vários fatores, tá, eu não deixei de viver a minha vida como eu não vivia antes, antes eu ficava enfurnado só na vida do meu relacionamento. Hoje eu vivo a minha vida, faço as coisas que eu gosto, do jeito que eu gosto, eu tenho uma independência um pouco maior do relacionamento, né? (Glauber)

Ah, ela me ajuda bastante, ela cuida quando eu preciso ser cuidado [...] me trata bem, não briga, não briga por bobagem, sabe? [...] Ela não é ciumenta, então, tipo, saio com os meus amigos numa boa, não me enche o saco, é mais ou menos assim: "Vou andar de moto", "Beleza, vai lá". (Guilherme)

A convivência com a parceira também tem desvantagens: as diferenças de opiniões e posturas, como solucionar certos impasses no namoro, o ciúme da namorada, a perda de espaços com amigos e família, como se pode ver em depoimentos a seguir:

É que fica muito próximo da pessoa, divergência de opinião talvez seja muito difícil, não escutar a pessoa talvez seja muito difícil também, talvez aquele caso de, como tá sempre junto, talvez você não preste atenção na pessoa. (Eduardo)

Ela é filha única e ela é mal acostumada com algumas coisas, porque você sabe como filho único é: é tudo pra ele, né, então o ego dele é na frente de todo mundo, né? Então é muita frescura, muita coisinha, picuinha, sabe, que às vezes se torna chato. (Glauber)

Os ciúmes, né? Os ciúmes é uma coisa que às vezes gera algumas brigas, tal... [...] Eu acho que o que segurou [...] foi a questão carnal mesmo, física, porque foi um namoro muito conturbado, a gente brigava muito, devido aos ciúmes dela, tudo que eu falava ela via os pontos negativos apenas, entendeu? Foi um namoro muito conturbado, 
assim, apesar de ter um bom relacionamento com a família dela, tudo. (Lucas)

Por exemplo: a mulher tem TPM. Não, é sério, cara, é muito mais sério do que as pessoas imaginam. Eu aprendi isso no meu segundo namoro, a mapear isso. Eu, agora, a primeira coisa que eu descubro sobre a minha namorada é o ciclo menstrual dela. Por que, o que eu faço: eu já me preparo psicologicamente pra aqueles três dias fatídicos, onde elas vão tá chutando tudo o que tiver pela frente, cê entendeu? Nesses dias eu fico quietinho [...] (Guilherme)

\subsubsection{A infidelidade}

A infidelidade amorosa pode ser definida como um segredo romântico, sexual ou envolvimento de caráter emocional que transgride o compromisso de um relacionamento exclusivo (ALMEIDA, 2007). Pode ser classificada em duas modalidades. Para Ahrndt (2005), a infidelidade sexual é qualquer comportamento relacionado a um contato sexual, como beijos, carícias íntimas e qualquer tipo de relação sexual. A infidelidade, para a mesma autora, diz respeito à formação de um vínculo emocional para com o afeto de outra pessoa e pode envolver os comportamentos de paquerar, marcar encontros, conversas íntimas, ou se apaixonar por outra pessoa que não o (a) atual parceiro (a).

Qualquer que seja o tipo de infidelidade, frequentemente gera no parceiro traído a raiva, a surpresa, desapontamento, rebaixamento da auto-estima, dúvidas acerca de si mesmo e depressão (ALMEIDA, 2007).

Dos dez entrevistados, apenas Leandro e Fábio afirmaram que suas exnamoradas foram infiéis. Leandro, em seu primeiro namoro, quando era adolescente e Fábio, em um de seus relacionamentos, que na época contava seis meses. Os dois jovens esclarecem também como se sentiram frente à infidelidade sofrida:

Ah, chorei pra caramba, eu não esperava, tal, via telefone, não sei... Eu devia ter... 13 anos mais ou menos, ela era mais velha, devia ter 16. E era algo que eu não esperava de ouvir assim, na cara dura, por telefone: "Ah, a gente vai namorar? Eu fiquei com um menino lá..." Assim, não tinha sentimento, eu acho que, na época, dessa namorada era algo mais... E eu ia namorar uma menina mais velha, "Pô, mais velha!", dentro da escola, do colégio, eu tava na sexta, ela na oitava, cria-se um ambiente, né? Mas aí chorei, sofri barbaridade, mas passou 
também, não demorou muito não, acho que foi coisa mais de ser novo, de ser mais moleque, assim... (Leandro)

Eu não esperava, a pessoa chegou e me contou. Ela podia ter chego e terminado antes, isso que foi foda, né? Eu acho que não foi honesto, ela achava que ela foi super honesta de contar. Eu falei: "Pô, você teria sido mais honesta se você tivesse terminado antes!" [...] Eu fiquei com vontade de bater nela, só que eu nunca bateria numa mulher. Eu falei pra ela assim: "Você vai ficar no quarto, você vai dormir aí senão eu vou sentar a mão na sua cara! Eu vou dormir na sala... [...] Demorou um pouco pra essa mágoa acabar. (Fábio)

Fica claro pelos depoimentos dos dois participantes o sentimento de surpresa frente à traição sofrida, expresso pelo trecho "Eu não esperava”, idêntico nas duas falas e os sentimentos de tristeza e mágoa experimentados por eles. Fábio se posicionou contra a traição em qualquer circunstância, o que justificava o término de seus namoros anteriores, como se visualiza no trecho abaixo:

Por que terminou? Porque eu vi que eu não ia comer só aquela mulher, cara, entendeu? O desejo não tava só mais pra aquela mulher, aí eu prefiro terminar, quando eu via que eu não ia dar conta de tá só com uma pessoa, terminava mesmo, era desse jeito. (Fábio)

Leandro, por sua vez, pontua que em seu segundo namoro residia em outra cidade e somente encontrava a namorada nos finais de semana. $\mathrm{Na}$ época, vivia com amigos em uma república estudantil e estava no início da faculdade, deixando claro em sua fala que foi infiel por diversas vezes. Entretanto, no namoro seguinte, a questão da fidelidade era algo de extrema importância, já que não via razões para ter outros relacionamentos:

Eu tive três namoradas na vida. A primeira eu fui chifrado, a segunda... A primeira durou um mês. A segunda três anos e eu não fui um cara honesto com ela, nem um pouco, em termos assim, de fidelidade. E a terceira, eu tava totalmente tranquilo, nunca traí ela, namoramos dois anos, acabou porque tinha que acabar. Então pra mim isso também já foi um crescimento, eu já enxergo isso um crescimento, cê tá entendendo? (Leandro)

Para Béjin (1987), houve uma mudança na concepção de infidelidade nas últimas décadas. Nesse período, observava-se a presença de uma dupla moral: a exigência de uma fidelidade absoluta por parte da mulher e a aceitação de uma fidelidade relativa por parte do homem. Para o autor citado, atualmente não se pode falar em uma norma de fidelidade universal. Os casais se mantêm fiéis para respeitar 
seus compromissos e porque também é de seu interesse permanecer desse modo. Correse o risco de sofrer represálias do parceiro e de ver destruída a relação caso se seja infiel.

Os discursos de Leandro e Fábio, quando relatam a infidelidade da parceira, parecem indicar que, ainda que eles reconheçam que a infidelidade feminina ocorre tão comumente quanto a masculina, têm de arcar com uma postura adotada pelas mulheres que ainda é considerada fortemente por eles como um traço masculino. É, na fala de Fábio, "se deparar com o igual" (sic).

De acordo com o IBGE (2003), 71\% dos pedidos de separação realizados por mulheres têm como principal razão a traição masculina. O Instituto Datafolha, em 2007, perguntou a 2093 entrevistados: “O que é mais importante no casamento?” A fidelidade aparece em primeiro lugar, com 38\%, seguida do amor (35\%), honestidade (15\%), filhos (5\%), vida sexual satisfatória $(2 \%)$ e dinheiro (2\%). Praticamente a mesma porcentagem de homens e mulheres elegeram esse valor como o requisito mais importante para um casamento feliz - 38\% e $40 \%$, respectivamente.

A mesma pergunta, respondida em 1998, obteve a mesma resposta de $23 \%$ dos participantes, porcentagem bem inferior à da pesquisa de 2007. Nesta, o amor foi elencado em primeiro lugar (41\%), seguido pela honestidade (24\%). Para Goldenberg (2010), a fidelidade se tornou um valor ainda mais básico para os casais ao longo dos anos.

\title{
4.7. A relação com os amigos
}

\begin{abstract}
A gente passou por um momento aí que foi bem louco, vamos dizer assim: faleceu um pai de um amigo nosso [...] E ele mandou, falou: "Pô, faleceu o meu pai", mandou a mensagem, "Rezem por ele", tal, tal, tal, tal. E nisso já começou a movimentação, pô, como é que nós vamos, quem vai, que horas que a gente vai. Pô, chegamo lá, tavam os oito lá, cara, em outra cidade. (Leandro)
\end{abstract}

Todos os entrevistados afirmam ter amigos homens e valorizarem muito esse tipo de vínculo, especialmente a sociabilidade que podem vivenciar com tais amizades. 
De forma geral, a relação dos participantes com esses amigos está ligada à realização de atividades como sair para beber, conversar, jogar futebol, jogar videogame e ir a festas.

Essa modalidade de relação adquire uma importância significativa na vida desses jovens na medida em que se abre a possibilidade de constituição de relacionamentos duradouros e verdadeiros, encarados por eles como fundamentais para sua vida cotidiana. Apreende-se em algumas entrevistas um destaque especial dado às amizades de longa data, estabelecidas na infância e adolescência:

[...] Alguns não sei por que, mas esses relacionamentos mais antigos, da época da adolescência, normalmente perduram por mais tempo (Guilherme)

Os temas mais conversados entre os participantes e os amigos são, predominantemente, trabalho, futebol e mulheres. Outros assuntos como política, tecnologia, economia e sociedade também foram citados por alguns dos jovens, mas de forma menos enfática:

\begin{abstract}
Ah, meu, homem só conversa sobre mulher, cerveja e futebol. Tipo, tem uns assuntos periféricos, assim, mas o principal é cerveja, mulher e futebol. A gente discute política, discute um pouco de dinheiro, de economia, fala um pouco de filosofia, fala sobre a sociedade, mas cinco minutos depois o assunto volta ou pra mulher, ou pra futebol, ou pra "Vamo buscar mais cerveja". (Bernardo)

A gente conversa muito de trabalho, de projeto de trabalho, muito, muito, a gente pensa o tempo todo em trabalho, pra ganhar dinheiro, o tempo todo. De mulher também, fala de mulher pra caramba, fala de relacionamento, como é que tá, reclama um pro outro, fala: "Preciso trocar uma idéia, preciso desabafar". É com o amigo que vai falar mesmo, né? [...] (Marcos)
\end{abstract}

Ainda nesse sentido, observa-se também que um espaço de compartilhamento de informações e opiniões é visto como muito positivo, possibilitando o aprendizado e a troca de experiências entre eles e os amigos:

Ao serem perguntados se dividiam suas experiências pessoais e seus sentimentos com os amigos do mesmo sexo, os entrevistados trouxeram as mais diversas respostas.

Leandro, por exemplo, destaca a transparência existente entre ele e os amigos, no que se refere à exposição pessoal e também ao posicionamento frente ao que se ouve do amigo: 
[...] Ele entende quando é só pra ele te ouvir, ele sabe quando ele tem que falar, ele sabe quando ele não tem que falar nada [...] "Pô, o Leandro quer vir aqui pra falar hoje". Eu sei que ele quer falar, eu vou ficar quietinho, deixa ele falar. Hoje ele veio aqui pra ouvir mesmo, sabe, hoje ele veio aqui pra apanhar na cara... "Cê é burro, cara? Cê é idiota? Cê não entende?", entendeu? Então esse negócio é muito aberto, é preto no branco mesmo, pra falar mesmo, em todas as situações, o que precisar, vai falar, não tem muito senão assim.

Houve aqueles que afirmaram que compartilham certos assuntos mais superficiais, ligados aos relacionamentos amorosos, ou à família, ou ao trabalho, entretanto não se sentem à vontade ou têm receio de expor sua subjetividade, dividindo sentimentos, aflições e preocupações, por não confiarem na discrição do amigo e serem mal interpretados ou incompreendidos por este. A fala de Aluísio vai ao encontro desse aspecto:

[Meus amigos] não têm capacidade de compreender isso, eu só divido hoje com... Parte dos meus sentimentos com a minha família, quando eu acho que dá pra dividir, com o meu irmão e com a minha analista. Aliás, 90\% dos meus sentimentos eu divido com a minha analista [...] Eu sempre fui um cara que quis entender tudo, até demais, então não compartilho com eles nada de sentimento, são amigos mais sociais, pra passear, pra jogar conversa fora. (Aluísio)

Esse depoimento talvez reflita a dificuldade do compartilhamento, de exposição da subjetividade, uma vez que, quando ocorre, se dá em um contexto analítico - mais reservado de julgamentos e preconceitos. Levanta também o receio e a desconfiança em relação às próprias amizades e que o diálogo de assuntos e vivências mais superficiais o faz sentir mais protegido ou menos invadido.

Sérgio, por exemplo, pontua que não se abre muito com os amigos, por ser muito reservado e "guardar para si" seus sentimentos. No entanto, enfatiza a utilidade do espaço do compartilhar:

[...] Compartilhar é bom porque você descarrega, você tira um negócio do seu ombro e coloca um pouco no dele, né? Então é você compartilhar energia, eu acho compartilhar, se for energia positiva, positiva, se for negativa, compartilhar energia negativa, é desafogar o homem, talvez desafogar o peso das costas, né? Então eu vejo como impossível não existir isso, impossível, impossível.

Bernardo, por sua vez, pondera que, ainda que enxergue a utilidade em partilhar, não se sente bem ao se abrir com os amigos: 
Eu não me sinto bem fazendo isso, já aconteceu, como eu te falei, de falar assim, de conversar, mas aí no outro dia eu me arrependia de ter falado: "Mas por que que eu falei? Não é da conta dele!" E isso tá errado, porque, pô, o amigo se importa com você, ele quer te ajudar, ele quer conversar com você, mas eu não gosto. Tipo, faz mais mal do que bem, faz bem, mas faz mais mal do que bem. (Bernardo)

Por outro lado, outros jovens como Glauber e Lucas pontuam que "falam de tudo" com os amigos, não demonstrando dificuldades, receios ou ressalvas em fazê-lo:

A relação é muito boa, são pessoas que eu convivo, tem vezes que a gente se afasta, tem vezes que a gente tá muito perto, eu me abro pra eles, falo de tudo e eles falam de tudo, entendeu? A gente é confidente de algumas coisas, são pessoas legais, tal... Então são pessoas que são companheiras, se você tiver numa situação difícil, com certeza ela vai tá lá pra te ajudar, como sempre teve. (Glauber)

[...] É um relacionamento sincero, na hora que eu tô com raiva, até pra mandar eles tomar no cu, eu mando, a hora que é pra dar um abraço que eu tô com saudades deles, eu dou um abraço. Eu tenho um relacionamento muito bom, transparente, com os meus amigos, não tenho aqueles receios de demonstrar sentimentos, não, é muito tranquilo [...] Então a gente conversa de tudo, cara, de mulher, futebol, das atualidades que estão ocorrendo no mundo, de besteira, de relacionamento de amigos [...] (Lucas)

O que parece ser comum entre todos os entrevistados é que se torna mais fácil dividir com os amigos conteúdos mais superficiais, que não envolvam tantos aspectos íntimos, referidos à sua interioridade.

Nesse campo da superficialidade, alguns dos entrevistados ainda destacam que é muito fácil se constituir uma amizade com homens, visto que estes são muito sociáveis e abertos a esse primeiro contato.

Outros ainda destacam que há amizades circunscritas a certos contextos e finalidades, como pode ser visualizado nos depoimentos de Sérgio e Guilherme:

[...] Você tem vários perfis e tipos de amigos: tem amigo que cê é confidente, tem amigo que é o baladeiro, tem amigo que é o cara que você discute o trabalho, tem perfis e perfis. Cê tem cada um com uma certa inteligência, digamos assim. Cada um com uma certa afinidade, tem certos amigos que você tem que você gosta de observar ele, tipo, como ele faz, pra onde ele vai, pra você seguir os passos, como se ele fosse um... Um guru, vamo dizer. Tem outros que é de igual pra igual, enfim.. (Sérgio) 
[...] Não, é que depende o amigo e o assunto. Porque tem amigos que entendem melhor um assunto, tem amigos que entendem melhor outro, talvez uma pessoa que tenha um ou dois amigos seja muito mais fácil. (Guilherme)

Guilherme e Fábio ainda descortinam outros aspectos da relação de amizade entre homens: a dificuldade de falar sobre relacionamentos e o receio de ser considerado homossexual ao partilhar certos assuntos mais íntimos:

Eu vejo que os homens conversam muito pouco sobre relacionamento, assim, conversar de fato. Às vezes a gente comenta uma coisinha ou outra, tal, mas conversa muito pouco. Homem, eu acho que conversa mais quando quer contar vantagem de alguma coisa pra outro do que conversar de fato, discutir alguma coisa séria com o amigo [...] (Guilherme)

Mas tem um distanciamento de homem, que sempre existe assim. $\mathrm{O}$ homem sempre tem medo de parecer veado pro outro quando vai conversar de algumas coisas, eu acho. O homem tem medo disso [...] (Fábio)

Para os entrevistados, os pontos positivos das amizades com homens repousam especialmente sobre ter companheiros com os quais dividirem momentos de diversão, distração, ter em quem confiar para contar alguns assuntos e ser aceito da forma como se é:

Ah, pontos positivos você tem companhia pra sair no sábado, um dia da semana pra se distrair, pra paquerar, pra um dia que você tá com uma garota, tem um amigo pra ir junto, ou só acompanhando, um casal... É gostoso, são colegas com quem eu falo sobre trabalho, com quem eu falo sobre faculdade, com quem eu passo uma hora pra relaxar mesmo, é quando cê não tá querendo pensar muito, entendeu? (Aluísio)

Ah, o ponto positivo é você poder compartilhar, é você poder aprender, se divertir, [...] Ser um tijolo numa casa. Então os amigos eu vejo como uma casa, como uma estrutura, o alicerce eu vejo como a família, digamos assim e os amigos são a parede, né, o tijolo. (Sérgio)

Glauber, Leandro e Lucas destacam ainda o conhecimento que têm sobre os amigos e a honestidade existente nesses relacionamentos:

[...] Um amigo é aquele cara que tá sempre do seu lado [...] Então ele sabe como você é sem um relacionamento, ou sem um problema, ou sem emprego, ou com emprego, ou com namorada, ele sabe como você é, sabe o seu jeito de agir, né? Então ele é uma pessoa que vai 
falar a verdade na sua cara: "Se toca desse relacionamento porque não é pra você”, né? (Glauber)

Então eu acho que são irmãos que cê vai falar de tudo: cê vai falar de mulher, de futebol, disso, daquilo, e cê sabe o que cada um gosta, o que cada um quer conversar, se você quer agradar o cara, se você liga no aniversário do cara, se você precisar levar um presente pro cara, cê sabe que cê vai levar, que o cara vai gostar, coisa assim, de amizade grande mesmo, sabe? (Leandro)

Acho que principalmente a transparência e honestidade que esses meus amigos têm, e afinidades, cara [...] O que prevalece pra mim determinar quais são esses amigos são principalmente a afinidade e a honestidade, né? [...] (Lucas)

Os pontos negativos citados pelos jovens estão relacionados às diferenças de opinião entre eles e os amigos e o modo como buscam solucionar as divergências. Alguns entrevistados mencionam que uma situação ruim que ocorre às vezes são os amigos tentarem impor uma opinião da qual eles discordam:

Às vezes esse amigo pode tentar, dependendo da característica dele, te impor o que ele acha, né? Então às vezes um amigo fala: "O que é certo pra mim pode ser pra você", impor o que é certo pra você. Eu acho que isso é às vezes um ponto negativo, tentar impor uma opinião dele pra você, né, a imposição. (Glauber)

Leandro faz referência ao fato de que a intimidade abre um espaço para que sejam feitas críticas difíceis de serem ouvidas, inclusive em situações de conflito ou dificuldade:

[...] Do mesmo jeito que os caras sabem de tudo, eles sabem seu podre também, que às vezes numa situação que cê não tá legal, o cara pega e solta alguma coisa que cê não quer ouvir naquela hora e se ele falar o que cê não quer ouvir, cê vai falar o que ele não quer ouvir. Cê sabe todos os pontos bons, todas as coisas, mas cê sabe todos os podres também, cara, entendeu? E num momento ali, cê vai acabar soltando. (Leandro)

Lucas e Marcos, por sua vez, relativizam o aspecto acima, aludindo ao fato de que dizer certas "verdades" aos amigos pode em um primeiro momento gerar mágoa e ressentimento; entretanto a situação geralmente se resolve em um momento posterior e a relação é retomada: 
[...] Amigo é o cara que às vezes você vai criticar ele ali, falar alguma coisa, por mais que você fale até num tom, sei lá, cê seja meio veemente, se o cara é seu amigo, ele pode até ficar bravo ali na hora, mas depois ele vai entender que você tá falando aquilo pro bem dele. (Lucas)

Acho que de repente um ponto negativo é que a gente fala as verdades mesmo na cara do outro, pode causar uma mágoa, mas depois a gente resolve e tá tudo certo. (Marcos)

Os jovens foram indagados também a respeito do que é necessário para se constituir uma amizade com homens. Alguns participantes destacam a facilidade de estabelecer contatos - ainda que superficiais - por parte do homem, o respeito, a confiança e a objetividade como critérios para se formar uma amizade. Todavia, o que é quase unânime para a formação desse vínculo, para os entrevistados, é a afinidade de interesses, de gostos e opiniões:

Cara, pra construir uma amizade com um homem não precisa muita coisa não, viu? Homem é bem diferente de mulher. Amizade mais superficial, vamo falar de coleguismo, qualquer um você constrói. Se você começar a falar de futebol, juntar numa rodinha... Isso que é legal de homem, cê vai num churrasco, tem uns caras lá, começa a tomar cerveja, todo mundo começa a conversar, a se entrosar, tal. (Aluísio)

Objetividade é uma das coisas, eu acho que cê não consegue construir uma amizade com homens sem ser muito objetivo, muito franco. Porque o homem cobra esse tipo de franqueza, né, eu prefiro que um amigo meu venha virar pra mim e falar assim: "Olha, nós tamo afim da mesma mina, vamo decidir com quem ela vai ficar", por exemplo, do que eu descobrir depois que ele tava lá, correndo por fora... Entendeu, eu ia ficar muito puto! (Guilherme)

Achar pessoas parecidas com você, pessoas que pensam mais ou menos como você pensa, que dêem mais ou menos o mesmo valor pra mais ou menos as mesmas coisas, cê tá mais ou menos com pessoas parecidas. (Bernardo)

E também um pouco de, acho que afinidade com a pessoa, né, tipo assim, ela tem mais ou menos o mesmo tipo de ideia, entendeu? Talvez até ideias diferentes, também ajude a concretizar essa amizade, porque é uma troca de informação entre essas pessoas. (Eduardo)

Afinidade, afinidade, seja lá qual for, afinidade de trabalho, afinidade de cerveja, afinidade de mulher, afinidade de tudo, qualquer coisa que você faça e que cê goste. (Sérgio)

Interessante observar que mais uma vez a afinidade é citada como um critério muito importante para o estabelecimento de relacionamentos, na opinião desses jovens. 
Esse aspecto também foi mencionado como fundamental para a constituição de um namoro e foi reiterado neste tópico.

Os entrevistados atribuem à afinidade um papel quase que indispensável para que eles possam lidar de forma satisfatória com o outro, ainda que a alteridade também apareça em algumas falas como um ingrediente a enriquecer a relação, tanto com amigos quanto com namoradas ou "ficantes". O que se pode questionar é como esses jovens lidam com as diferenças entre eles e seus interlocutores, de que forma procuram solucionar conflitos e divergências.

Dos dez jovens entrevistados, quatro afirmam fazer parte de atividades constituídas somente por homens: Bernardo e Lucas jogam futebol semanalmente, Sérgio é membro de um grupo de emails e Guilherme anda de jipe e quadriciclo com os amigos. Marcos e Eduardo mencionam que jogaram futebol durante um tempo, mas não o fazem mais. A esse respeito, Eduardo faz referência ao clima de competição presente entre os participantes:

Tinha uma disputa muito grande, tipo assim... Uma disputa natural de quem ia ganhar, aquela disputa de querer ser melhor, tal, isso me irritava [...] Eu acho um negócio muito vil, muito baixo, entendeu? Cê tá lá pra se divertir e vira, assim, uma disputa e acaba-se até brigando, entendeu? Não era um ambiente legal, não era um ambiente de amizade, era um ambiente de disputa, né? [...] Era uma disputa de talento, de força, de resistência [...]

\subsection{A relação com as amigas}

Teve até uma propaganda da Sprite que fala do João Gordo, com um menino e uma menina que são bons amigos, tipo assim: tudo o que cara vê na amiga, ele é seduzido por ela a qualquer momento, então que não existiria amizade entre homem e mulher. Por quê? É aquele negócio: um homem e uma mulher, se uma sua amiga te chama pra chincha, como eles falam, te chamam pra ir pra cama, só se o cara for muito amigo mesmo, se for completamente diferente do que o cara vai negar, negar ir pra cama com a menina, entendeu? Então a gente sempre pensava: "Será que existe mesmo uma relação ou se na hora que falam da questão sexual se a mulher atrai o cara, será que o amigo vai resistir a essa tentação?", entendeu? A gente sempre discutiu 
sobre isso e a gente nunca chegou numa opinião... (Glauber)

A relação com as amigas foi trazida pelos jovens com uma forma de sociabilidade, marcada por uma variedade significativa de contrastes e intensidades. Talvez tenha sido o tema em que emergiram as mais diversas respostas, opiniões e posições por parte dos entrevistados.

Todos os dez participantes mencionam ter amigas e esse vínculo foi constituído especialmente no trabalho, durante a faculdade ou ainda na época do colégio. Ao tratarem desse tema e da forma como a amizade se construiu e se mantém, os jovens apresentam mais uma vez o contraponto entre homens e mulheres, mencionando inclusive limites dessa modalidade de relação ou a dificuldade em estabelecê-los:

Por exemplo, eu não ligaria pra uma amiga: "Vamo tomar uma cerveja?" Mas, por exemplo, na faculdade, a relação é de trabalho, é muito profissional também, ou seja, é muito as coisas que elas fazem. (Eduardo)

[...] Mulher gosta de ser ouvida, a mulher gosta que você fique quieto e elas contam a história que tá acontecendo delas, com os paqueras, não sei o quê. E como não são assuntos que normalmente interessam pro meu perfil, eu tenho que tá com um certo nível de paciência pra fazer isso. (Guilherme)

Os assuntos mais tratados com as amigas são predominantemente relacionamentos e trabalho; os jovens mencionam que o falar sobre relações se dá especialmente por iniciativa das amigas, que compartilham suas questões e suas experiências. Aparece ainda, como se vê no depoimento de Glauber, a referência a assuntos "banais" femininos, como aspectos estéticos:

A gente fala bastante sobre relacionamento, fala bastante sobre namorada, elas falam mal de homem, eu concordo: "É isso mesmo, homem é tudo uns filho da puta" e... Porra, é verdade, mulher fala muito mais sobre relacionamento do que homem. (Bernardo)

Mas a maioria das mulheres, elas ficam conversando de coisa banal, né, "É porque o cabelo, porque não sei o quê, por causa do brinco, por causa da unha, e não sei o quê da novela, cê viu aquilo outro?", sabe? Aí surge um papo interessante, aí às vezes eu falo alguma coisa. [...] Porque homem não tem paciência, eu não tenho paciência pra essas coisas. Ai homem vai lá e dá uma patada, né, e às vezes "Larga mão, tá bonito esse cabelo". (Glauber) 
A maioria delas conta os problemas da vida delas, esse é o papo típico que as mulheres gostam. Eu vejo assim, uma diferença dos meus amigos pra quando eu tô com as minhas amigas: elas gostam de conversar sobre a vida delas e da vida dos outros. E os meus amigos gostam de conversar de assuntos diversos, mas raramente envolve a vida dos outros, entendeu? (Guilherme)

Os pontos positivos da amizade com mulheres estão ligados especialmente à perspectiva feminina que as amigas podem oferecer diante de situações vividas por eles. Nesse sentido, para os entrevistados, a sensibilidade feminina é considerada como uma vantagem, uma vez que, a partir da troca, esses jovens podem aprender mais sobre o mundo feminino e como agir com as mulheres. Além disso, ter amigas significa a possibilidade de conhecer mais mulheres e, com isso, expandir o leque de contatos - e, por conseguinte - de conquistas:

\begin{abstract}
Além de ela ser uma pessoa muito imparcial nas opiniões dela, ela tem o lado feminino ali, entendeu? Então às vezes, ela consegue me fazer enxergar uma coisa que o homem não enxergaria, por exemplo, pelo fato de ele ser homem. (Lucas)

Amigas trazem amigas, se ela é minha amiga, vai ter uma amiga ali que... Mulher atrai, mulher sempre anda com mulher. (Fábio)

[...] Ela tem uma sensibilidade diferente da do homem, às vezes ela vê de uma maneira diferente. Então o meu relacionamento com as meninas é assim: eu troco, de trocar idéias de coisas que você não troca com outro cara e elas se abrem quando falam. Então você consegue ver uma sensibilidade diferente. E outra: elas conhecem outras mulheres (Glauber)
\end{abstract}

Outro tema, enfatizado por Aluísio, refere-se à exposição dos sentimentos às amigas, a qual parece se dar de forma menos vergonhosa ou intimidadora, o que pode sugerir que, diante de mulheres, mais abertas a questões referentes ao universo de sentimentos e emoções, os homens sintam-se mais à vontade e menos temerosos em expor facetas de sua própria subjetividade:

[...] Parece que mulher te julga menos que o homem. A mulher parece que te condena menos [...] Parece que, com mulher, a minha desculpa serve um pouco mais, então com mulher eu consigo mostrar que não deu certo... Pra uma amiga minha, mostrar que não deu certo com fulana é mais aceitável do que eu dizer isso com um amigo meu. Então, parece que eu sinto que é mais acolhedor, entendeu? (Aluísio) 
A fala de Aluísio permite constatar que os homens sentem-se mais à vontade com amigas, pois não estão competindo com elas, o que ocorre no relacionamento com outros homens. Esse aspecto da sociabilidade com mulheres próximas pode ser acrescentado ao comentário anterior e reforça a suposição de que os homens sentem-se menos vulneráveis quando se relacionam com mulheres, diante das quais as amarras que freiam a expressão de sua subjetividade são, momentaneamente, postas em suspensão.

Por outro lado, pontos negativos, como ciúmes por parte dos informantes - e das amigas também - também foram mencionados:

A mulher é muito ciumenta, né? Tanto as amigas são ciumentas, quanto a namorada é ciumenta, então... Cê tem que medir o que cê fala justamente por isso, pra você não arrumar problema, né? (Marcos)

Se eu dei um beijo na mina ontem, a gente sai de novo hoje porque a gente é amigo e ela fica com outro cara, eu fico... Eu não, não exteriorizo, não passo a menor pista disso, mas por dentro eu fico com ódio [...] Fico com ciúme mesmo, ciúme igual de namorado, sabe quando você vê um cara xavecando a sua mina? (Bernardo)

A oscilação presente na fala de Bernardo, que sente ciúme mas que procura não exteriorizá-lo, bem como as demais falas, mostra o tênue limite entre amiga e "ficante" e como a primeira pode tornar-se eventualmente mais do que amiga.

Para alguns dos entrevistados, o interesse deles em relação às amigas foi considerado uma situação bastante delicada:

[...] Em relação de amizade homem e mulher é foda, porque às vezes rola um interesse de um lado, não rola do outro, às vezes rola só uma vontade sexual e não de se envolver e aí você tem que controlar isso, isso é difícil, entendeu? (Aluísio)

O ponto negativo é quando você começa a se interessar a ponto de querer ter um relacionamento, um relacionamento mais emocional, mais... Não um relacionamento mais físico, mas mais emocional, aí pode atrapalhar. (Sérgio)

Relacionado a este último tópico, uma das perguntas feitas aos entrevistados foi: "É possível a amizade entre um homem e uma mulher?" A maioria dos jovens respondeu que sim, mas uma amizade entre os sexos é possível com a ausência de um componente: a atração sexual. Quando não há interesse por parte deles, parece ficar mais fácil para construir e manter o vínculo sem sofrer tantos prejuízos. 
Sobre diferenciar a amizade com mulheres e as relações afetivo-sexuais, como uma "ficante" ou uma namorada, algumas falas mencionam que com a namorada há a presença da atração física e intimidade sexual, elemento de diferenciação importante em relação às amigas. Além disso, a namorada é considerada uma grande amiga, com quem se pode compartilhar mais:

Primeiro, pelo fato de ser namorada, né, você tem uma liberdade bem maior. Agora, amizade em sim, cê tem tanto com amiga, quanto com ela, a namorada. Acho que a diferença seria mesmo... Não sei te falar... Talvez a falta de interesse físico... (Eduardo)

Ah, são diferentes, porque com as amigas não tem uma intimidade, eu não vou conversar de coisas com as minhas amigas ou falar sobre determinados assuntos, ou tocar de uma maneira diferente numa amiga minha que eu faço com a minha namorada [...] (Glauber)

A amiga consegue manter uma neutralidade sobre a situação que às vezes uma namorada não consegue manter, pelo sentimento de homem e mulher, carnal, e não pelo sentimento de amizade, que é o sentimento de irmão, por exemplo, entendeu? Eu acho que o principal fator é esse, é manter a neutralidade, a imparcialidade em determinados assuntos. (Lucas)

[...] A sua namorada, por definição, é uma grande amiga sua, tá? E tem que rolar aí uma certa cumplicidade, tal, como rolaria com uma amiga, senão... Só que tem, lógico, tem os aspectos sexuais envolvidos aí na brincadeira, que você não tem com as amigas, mas tem com as namoradas [...] (Guilherme)

Contudo, em seus depoimentos, os jovens trazem uma dificuldade em discriminar os limites entre uma amizade e um possível envolvimento com as amigas.

O interesse físico e/ou afetivo surge nos depoimentos como um elemento que traz bastante ambivalência aos jovens: por um lado, muitos deles afirmam que ter interesse por uma amiga carrega consigo uma situação incômoda, uma vez que a amizade pode ser danificada por um envolvimento que talvez seja temporário e superficial. Além disso, eles precisariam se "controlar" para não investirem sobre a amiga. Por outro lado, o desejo pela amiga é algo que eles também querem concretizar.

Ah, eu misturo bastante, viu? Ih, eu começo a ter tesão por amiga minha, tem umas aí que eu transaria numa boa [...] Às vezes eu sinto sim uma vontade de homem de ter aquela mulher que cê tá vendo ali do teu lado. E aí, lógico, cê tem amizade, a coisa fica um pouco mais difícil e às vezes você vê que você nem quer namorar com aquela garota ou continuar tendo algo mais concreto. Então, isso é um pouco difícil de se controlar. (Aluísio) 
Eu tive meninas que eu comecei sendo amigo, me relacionei e depois acabou, não deu certo, conseguimo levar numa boa a amizade, como teve mulheres que eu comecei como amigo, me relacionei e depois, da maneira que acabou, como acabou, não conseguimos mais manter a amizade por causa disso, por causa do sentimento que teve, carnal, homem e mulher [...] (Lucas)

É muito raro você ver uma amizade entre um homem e uma mulher que já houve uma atração entre os dois, né? As próprias meninas falam: "Ah, se acontecer, se rolar entre a gente, acaba a amizade". As meninas falam isso, os homens nem pensam, rolou, rolou, a amizade continua a mesma. Porque ele pensa com a cabeça de baixo, entre aspas, né? (Glauber)

[...] Eu vejo assim: uma coisa que pode dificultar isso, essa amizade entre homem e mulher é o interesse, o interesse em ficar com a pessoa. Se você tem interesse, pode atrapalhar, pode atrapalhar o seu posicionamento, pode atrapalhar o seu comportamento. Agora, se você não tem interesse, pode realmente levar uma amizade como se fosse homem mesmo, aí tanto faz o sexo. (Sérgio)

Só que são amigas, mas parece que nunca são amigas, amigas, né? Assim que eu digo, como um amigo, sempre se deixar, a gente gostaria que acontecesse alguma coisa, né, principalmente as bonitas, né? Então isso existe. (Fábio)

Todos os jovens afirmam já terem se interessado por amigas. Para Sérgio, quando o "ficar" se restringe à atração física, a amizade pode ser preservada; entretanto, quando a relação extrapola para o nível sentimental, pode ser mais difícil continuar a amizade. Já Marcos aponta que, ainda que tivesse interesse da sua parte, a amizade acabou se constituindo como um impeditivo para que ele tentasse algo com a amiga:

Ah, muito louco, né, acabou não dando certo, nem fui atrás, né, cê acaba: "Não, não tem nada a ver, né, é minha amiga". Mas o negócio é meio que platônico, né, cê queria, mas cê não podia, né? É mais ou menos por aí.

Eduardo, Sérgio e Marcos ponderam que se sentem mais à vontade para compartilhar com amigos do que com amigas, ao passo que Aluísio, Leandro e Fábio afirmam o inverso:

Ó, com as minhas amigas eu até compartilho mais do que com os meus amigos, até falo mais o que tá acontecendo, porque eu sinto que a mulher ouve bem mais do que o homem. Então com elas, eu até compartilho, não amiúde, entendeu, não profundamente, porque aí eu acho que não dá. Então eu conto: "Ó, eu tô saindo com fulana, aconteceu isso, isso e aquilo..." E por ventura eu ligo pra uma: 
"Nossa, o quê que eu faço? Eu não sei se eu convido pra sair..." (Aluísio)

Para os informantes, respeito, cumplicidade e afinidade são pedras fundamentais para a construção de amizades com mulheres.

Glauber diz comentar sobre relacionamento com amigas, porém de forma superficial, pouco profunda, sem tantos detalhes nem exposição de sentimentos. Para Lucas e Marcos, a transparência é um elemento importante para a formação de amizades com as mulheres, porém os jovens pontuam que não conversam alguns assuntos considerados de cunho "masculino", especialmente no que diz respeito à sua sexualidade. Tal postura parece indicar que ser transparente com as amigas deve estar inscrito dentro de certos limites estabelecidos, é uma transparência relativa, sem exposição tão pronunciada:

Então é um relacionamento também de bastante transparência, claro, tirando determinados assuntos de cunho masculino, o resto é normal, é o mesmo relacionamento com um amigo. (Lucas)

Um ponto a ser ressaltado é a distinção feita entre o comportamento das amigas e dos amigos diante de situações em que os entrevistados estão com problemas de relacionamento, por exemplo. Alguns jovens apontam que as amigas têm uma postura de acolhimento e receptividade às dificuldades vividas por eles, muitas vezes levandoos a se expressar e a pensar sobre a situação; entretanto, outros participantes enfatizam a "praticidade" masculina em tocar a vida sem dar tanta importância ao fato:

[...] Eu acho que a mulher é mais sensível, ela tem uma sensibilidade maior, ela trata de uma maneira diferente, às vezes ela sente mais, tipo, é uma injeção a mais, pô, sei lá, o cara tá precisando de um carinho, a mulher sente melhor isso [...] Já vem, te abraça, quer às vezes te pôr no colo mesmo, falar: "Fica aqui, chora, deita, fica aqui"" [...] (Leandro)

Eu acho que a diferença entre amigo homem e a mulher é que o amigo homem dá mais força pra você levantar do que uma, uma mulher. Eu acho que ela dá força, mas é uma força diferente, elas vão... Como elas vão pela emoção, elas vão até à última gota, até o último dia pra saber se é aquilo mesmo que tá acontecendo na sua vida ou não, pra você passar pra frente, elas são mais cautelosas. O homem não, joga pra trás e bola pra frente. (Glauber)

Eu vejo que o homem é muito mais prático, ah, cê tá com um problema com uma mulher, cê tá com um problema de relacionamento, o cara vai ser mais prático: "Ah, vamo tomar uma 
cerveja, vamo beber, vamo ficar com outras e vamo fazer putaria!" A mulher não, a mulher eu acho que vai pro lado mais emocional, vai procurar entender, vai pensar mais pelo lado da mulher que você tá do que na sua cabeça. (Sérgio)

Tais depoimentos encontram eco em Goldenberg (2010, p.205):

Os homens querem esquecer [os problemas], as mulheres relembram incessantemente. Eles querem resolver o problema, de preferência muito rapidamente. Elas querem refletir sobre o problema, sem necessariamente resolvê-lo. Os familiares e amigos íntimos são fundamentais para reforçar tanto a postura de esquecer como a de refletir sobre os problemas.

A respeito da postura masculina de querer "esquecer" os problemas, emergem alguns questionamentos: ao agir do modo como Glauber e Sérgio assinalam nas falas acima, os homens também expressam suas dificuldades em expor seu sofrimento, suas dores, sua subjetividade. Ou o espaço da amizade com os amigos não está tão aberto para o compartilhamento desse tipo de assunto?

O que indicam as falas é que há uma dificuldade em expressar de forma profunda o que eles de fato sentem em relação às amigas e também aos amigos. $O$ compartilhamento é parcial e, com os amigos, os relatos parecem trazer um componente sentimental e afetivo ainda menos pronunciado, sob o risco de serem considerados "sensíveis" demais, característica considerada eminentemente feminina.

\subsection{Ser solteiro}

[...] Quando eu terminei meu namoro, era uma situação: "Puta, e agora, solteiro? Como é que vai ser?" Demorei pra engrenar e agora eu penso: "Puta e agora como é que vai ser namorando de novo?" Sabe, ligando, dando satisfação... (Leandro)

Os entrevistados, de forma total, disseram se sentir muito bem sendo solteiros. As maiores vantagens residem em ter menos responsabilidades a serem assumidas, menos despesas a serem pagas - especialmente para aqueles que ainda moram com pelo 
menos um dos pais - o que possibilita juntar mais dinheiro para ser investido em planos futuros, como a formação profissional, bens materiais e o próprio casamento.

Dos dez entrevistados, seis moravam com pelo menos um dos pais: Aluísio, Bernardo, Marcos, Glauber, Leandro e Guilherme. Destes seis, os quatro primeiros nunca haviam saído da casa paterna. Lucas e Fábio moravam com amigos, Eduardo morava com a namorada e Sérgio morava sozinho.

O ato de saída da casa dos pais, sob a perspectiva ocidental, demarca a porta de entrada para o mundo dos adultos. A geração canguru, descrita dessa forma pela mídia por sua analogia com o mamífero marsupial australiano cuja fêmea dá abrigo aos filhos em sua bolsa ventral - se caracteriza pelo adiamento da saída da casa paterna e do prolongamento da convivência com a família de origem (HENRIQUES; JABLONSKI; FÉRES-CARNEIRO, 2004). Deixar a casa dos pais e se instalar em uma casa própria requer independência financeira e também emocional, abrindo a possibilidade da expansão da rede social para além do núcleo familiar.

A geração canguru, formada no seio da família de classe média urbana brasileira, se expressa por incluir jovens que estão aptos para a vida profissional, mas que parecem não estar prontos para a vida fora da casa paterna.

Interessante pontuar que os seis jovens que ainda residiam com os pais teriam condições de se sustentar sozinhos, pois são independentes do ponto de vista financeiro, mas mesmo assim preferem continuar residindo com a família. Essa situação parece não trazer prejuízos a eles, pelo contrário, morar com os pais traz suporte emocional e conforto. Um questionamento pertinente seria se estes jovens escolhem permanecer na casa paterna frente ao mundo de inseguranças no trabalho, nos relacionamentos afetivos e sociais, evitando assim sua exposição à difícil realidade fora do domínio familiar.

Outro fenômeno observado por meio das entrevistas e apontado por Paul (2003), nos Estados Unidos, é a geração boomerang. Neste caso, os jovens deixam a casa paterna por volta dos 18 anos e vão para as universidades, em outras cidades; após a conclusão dos estudos, retornam para a casa dos pais. Esse quadro pode ser visualizado nos casos de Leandro e Guilherme.

Os entrevistados ainda atribuíram um valor fundamental à liberdade do solteiro, de fazer o que quiser e não ter a obrigação de dar satisfações de seus atos a uma companheira, por exemplo. 
Outro aspecto benéfico da solteirice, para eles, é a possibilidade de buscar suas conquistas profissionais de forma mais livre, tendo mais tempo, energia e disposição para investir em sua carreira - o que se torna difícil quando se está casado e com filhos:

Você não dá satisfação pra nada, pra ninguém, é o ciúme inverso. Ninguém apita nada, você decide, você é dono das coisas boas e dos espinhos que você tem também. (Fábio)

Ser solteiro é bacana, entendeu? Assim, desde quando eu me tornei maduro, eu venho vivendo uma vida solteiro, principalmente por não morar mais com os meus pais, é uma coisa muito boa. Só que agora que eu tô conquistando o meu sucesso profissional, eu já to começando a planejar a vida matrimonial, eu já tô começando a planejar isso. (Lucas)

A vantagem de tá solteiro é de poder fazer o que eu quiser, sem dar satisfação pra ninguém, se eu for onde eu quiser e fazer o que eu quiser fazer, eu vou fazer, sem arrependimento nenhum. (Leandro)

Para os entrevistados, ainda existe uma diferença entre ser solteiro com e sem namorada, como se pode ver pelo depoimento de Eduardo:

Solteiro sem namorar, assim, cê tá livre pra fazer o que cê quiser, com outras pessoas, conhecer outras mulheres e tal, cê não tem essa responsabilidade, por exemplo, de tá com uma pessoa só. Solteiro namorando? Talvez cê não tem a responsabilidade de manter uma casa, de manter uma família, cê tá curtindo uma parte boa do relacionamento, sem chegar ainda na tormenta.

Eu acho que esse é um ponto positivo dos homens que... Não cobram muito da gente, a gente pode chegar nos 30 e poucos anos solteiro que ninguém fala muita coisa, a mulher já não... Eu acho que hoje eu sou solteiro não é... É por uma condição interna minha. Eu vivo bem, eu acho que eu ainda preciso ser solteiro um tempo (Aluísio)

Ao tratar das desvantagens de estar solteiro, alguns dos entrevistados se referem à solteirice sem namorada, pontuando que às vezes é ruim não ter uma companheira para dividir sua vida cotidiana, as conquistas e as tristezas diárias. Glauber menciona que um ponto negativo são os gastos excessivos com diversão, como festas. Lucas ainda assinala que vivenciar momentos especiais ao lado de alguém de quem se gosta é "infinitamente melhor" (sic) do que com uma companhia casual:

Uma namorada faz falta, às vezes, assim, vamo dizer assim: tem tipo, sei lá, cê tá afim só de ficar abraçado com alguém, ou reclamar de alguma coisa, conversar [...] Bernardo 
[Quando está sem namorada], a gente gasta demais, a gente gasta muito com balada, com coisa fútil, supérflua, entendeu? Coisa que você não precisa, o desejo é mais aflorado porque você não tem tanta responsabilidade, então você joga tudo pro alto, né, vamo aí, você vai como a onda leva, né?(Glauber)

[...] Eu acho que a desvantagem é você não ter aquela companheira ali, numa hora que você precisa, ou pô, numa hora de alegria também, não é só numa hora... Pô, às vezes você tá num lugar show de bola, aí cê fala: "Puta, queria que ela tivesse aqui comigo desfrutando desse lugar maravilhoso, desse sentimento de felicidade", que às vezes você quer dividir ele com a sua companheira ali, eu acho que tem essas desvantagens de ser solteiro. (Lucas)

No caso de estar solteiro com namorada, a maior desvantagem é não poder se aproximar de pessoas que eles consideram interessantes a fim de ter um envolvimento:

Quando você tá namorando solteiro, você pode ter... Sei lá, vontade de conhecer outras pessoas, acho que é isso. Essa falta de liberdade também... (Eduardo)

Esse depoimento de Eduardo ilustra um dos valores de alguns dos entrevistados frente ao relacionamento com a namorada: a seriedade do pacto de fidelidade entre os parceiros. Essa fidelidade é considerada pedra fundamental para a manutenção da relação e muitas vezes exerce um papel inclusive de restrição a certos comportamentos diante de outras mulheres. A fala supracitada indica que, ainda que surja o desejo em conhecer outras pessoas, essa vontade deve ser abandonada em prol da continuidade do namoro, pois pode levar à infidelidade.

\subsection{Falando sobre o casamento...}

Pra cada casal que cê me falar que tá junto há dez anos, eu te falo cinco que se separaram em menos que isso [...] Eu sei que um dia eu vou querer, mas não é uma coisa que eu penso, não faz parte do cotidiano (Bernardo)

[...] O casamento é uma coisa importante, muito importante, eu acho, que não é qualquer um que casa, que pode casar, como diz a minha vó: “Casar não é casaca”, ela fala. (Glauber) 
A primeira questão dirigida aos participantes no tocante a essa temática foi " $O$ que vem à sua mente quando ouve a palavra casamento?”. Eis algumas das respostas:

Uma responsabilidade que você vai assumir, entendeu, com outra pessoa, mas uma responsabilidade perante a sociedade civil. (Eduardo)

Casamento pra mim é dinheiro, eu sou advogado, eu faço um divórcio por mês. E cada divórcio é 600 pau, então... É verdade, cara, a galera casa pra separar! Só quem se dá bem com casamento hoje em dia é advogado (Bernardo)

O que chamou a atenção na resposta de Bernardo e foi anotado em diário de campo, após a entrevista, foi não apenas a frase inicial, mas a forma como a emitiu, dando a impressão de uma resposta quase automática.

Necessário ressaltar que o depoimento de Bernardo acerca desse tema se destaca dos demais pelo valor dado ao casamento, aproximando-o de uma negociação financeira. Entretanto, essa associação se dá ao se referir ao divórcio. O casamento parece, segundo essa fala, estar intimamente ligado ao dinheiro pelo seu fracasso - o divórcio - uma vez que advogados recebem honorários quando da dissolução da união. Lembrando também que Bernardo foi o único entrevistado cuja formação acadêmica é Direito.

Um ponto comum que aparece nas respostas de Glauber, Leandro, Lucas e Guilherme é o casamento ligado diretamente à constituição de uma família, com a chegada de filhos:

Uma coisa natural, que vai acontecer, é uma fase da vida de respeito, porque você tá fazendo, você tá se unindo a uma pessoa por um bem comum, e casamento significa filho também, né? Então você tá unindo com uma pessoa, com um outro ser, que tem pontos de vista diferentes que o seu, pra formar um novo ser que vai vir pro mundo e tentar passar o que ele conhece pras outras pessoas e aprender aqui também. (Glauber)

Eu acho que eu vou casar, vou ter filho, pretendo casar, ter filho... Acho que vai ser mais uma etapa da minha vida... (Leandro)

Casamento, o primeiro de tudo é você começar a constituir uma família, então eu vejo casamento, eu vejo você ser uma pessoa, que, a partir dali, você não tem uma vida mais sozinho, você tem uma vida com outra pessoa [...] Casamento é muito isso, você pára de pensar só em você e você começa a pensar em duas pessoas, que é você mais a pessoa que você casou. (Lucas)

Eu não tenho nenhuma aversão, é o que eu te falei, eu planejo até, eu planejo ter um filho, tá nos meus planos de vida isso. No momento, 
não é a hora, é isso que passa pela minha cabeça, ainda não tá na hora, mas eu quero [...] (Guilherme)

Dados semelhantes foram encontrados por Féres-Carneiro (2001) em pesquisa sobre a construção da identidade conjugal no casamento contemporâneo.

Outro aspecto levantado por Lucas, Marcos e Fábio é o caráter vitalício do casamento, que na opinião deles deve acontecer uma vez só:

[...] Eu acho que o casamento pra mim é uma vez só, se não der certo, beleza, tem as suas exceções, mas hoje eu penso em casar porque eu quero ficar com aquela pessoa o resto da minha vida. (Lucas)

É uma experiência única, casamento pra mim é assim, cara: eu acho que tem que ser muito bem premeditado, porque é uma vez só. Eu não casaria pra me separar, por exemplo. Eu nunca me casaria pensando: "Ah, tudo bem, se eu não gostar, eu vou separar". (Fábio)

Eu acho que casamento é um negócio pra sempre. Então, cê falar: "Eu vou casar, eu vou casar", tem muita gente, o cara: "Ah, fica dois anos..." Oito meses com a mulher, dois aninho com a mulher, já vai: "Oh, vou casar!" Eu, pelo menos, eu acho, eu falo: "Nossa, cê vai casar já?", né? Porque eu acho que é um negócio muito sério pra você tomar uma decisão tão rápida, né? Eu acho que dois anos é pouco pra você namorar. Então casamento é um negócio pra sempre. Se você não planejar, se você não tiver certeza de quem que cê quer... Porque não adianta cê casar e depois largar, né? Casamento é uma vez só, né? (Marcos)

As falas acima são interessantes, uma vez que o número de separações e divórcios vem aumentando na sociedade brasileira ao longo dos anos. Podem indicar também o desejo de que os relacionamentos sejam bem sucedidos, independentemente dos fatos se apresentarem de outro modo. Rodrigues (1984) cunha o termo "otimismo ingênuo", de acordo com o qual há uma superestimação da capacidade de resolver coisas, ainda que estejam relacionadas a acontecimentos ou atividades inalcançáveis ou irrealizáveis. O que pode estar embutido nesse sentido é um mecanismo de defesa para, de certa forma, negar a realidade adversa que os rodeia.

Os três depoimentos ainda indicam que, para um casamento acontecer, é fundamental muita reflexão, a fim de que a decisão por se unir a outra pessoa seja madura. O sofrimento e a frustração pela dissolução do matrimônio são encarados como muito intensos. As falas convergem para a força que o casamento ainda possui não só nos discursos, mas também nas práticas de jovens de camadas médias, como eles. Para Lucas e Marcos, por exemplo, o casamento se configura como um projeto a ser 
construído paulatina e cotidianamente, até ser concretizado. E essa construção é permeada, necessariamente, por um aprofundamento no conhecimento do parceiro.

Bernardo, por sua vez, discorda dos depoimentos anteriores:

[...] Se eu viver mais dez anos, se eu sobreviver até uns 70, 80 anos, eu sei que eu vou ter casado, sei lá, umas três vezes. Eu tenho certeza.

Eduardo, que namora há um ano e três meses e estava morando com a namorada há cerca de um mês, afirma que se casaria para realizar o desejo da parceira, mas não o dele próprio. Pontua também que já se sente casado com a namorada por morarem juntos e um cuidar do outro.

Os participantes também expressam o seu desejo - ou sua recusa - em relação ao casamento, tanto civil quanto religioso:

Sabe que é engraçado, até uns anos atrás, eu tinha um sonho de casar, de entrar na igreja. Eu sonhava com isso, hoje eu não sonho não [...] Eu tenho vontade, assim, assim, de morar com uma mulher. Eu não tenho vontade, eu não vejo o porquê entrar numa igreja pra casar, pra mostrar pros outros. Eu acho que eu casaria no civil, depois de tempo, mais por uma segurança, numa questão jurídica, de me proteger. (Aluísio)

[...] Às vezes eu penso, "Será que eu caso? Será que eu não caso?" Hoje nossa vida tá tão complicada! [...] Então eu penso em casamento por quê? Porque eu quero ter o meu espaço, eu posso ter sozinho, mas é muito legal, imagina eu viver velho, com 40, 50 anos e sem nenhuma companheira pra mim? (Glauber)

Eu não me vejo solteiro a vida inteira, na balada, catando uma mulher por semana, mudando, e nessa bagunça que entra... Acho que pra mim faz parte culturalmente, eu venho com isso, e pessoalmente também tenho interesse [...] Eu gostaria de casar, igreja, bonitinho, tal. (Leandro)

Eu só acho que o casamento seria uma vantagem no momento em que eu fosse ter um filho, senão, não vejo porque, entendeu? (Guilherme)

(..) O civil, perante a lei, sim, é importante, mas pra mim o peso do espiritual é maior do que o civil. É o que me importa mais [...] Eu sou muito místico nesse ponto, eu levo muito a sério [...] O caminho da fé, assim, essa lei de Deus pra mim é muito importante, essa coisa invisível, acho que tem que existir. (Fábio) 
Nota de diário de campo:

As falas de Fábio a respeito de sua religiosidade e espiritualidade foram muito enfatizadas ao longo da entrevista. Ele se disse muito católico e que possui muito respeito à religião que professa, buscando seguir os princípios e valores de sua fé. Entretanto, quando se refere ao matrimônio, afirmou que, apesar de seu profundo respeito pelo simbolismo e pelo valor da instituição, não faz planos de se casar. $O$ casamento, um dos maiores sacramentos da Igreja Católica, não é considerado como um projeto de vida do jovem, demonstrando que essa adesão ao catolicismo se mostra parcial, especialmente no tocante à sexualidade e ao casamento.

Em algumas falas dos entrevistados, o casamento também aparece como uma solução para a solidão. Interessante notar que alguns deles, como Glauber, ao se projetarem no futuro, o fazem muitos anos adiante, no início da velhice. Nesses recortes temporais, emerge o medo de ficar sozinho, de não ter uma companhia para dividir os últimos anos de vida. Surge também a valorização de um relacionamento mais estável e profundo que, embora ainda não se queira ou consiga vivenciar - como na fala de Leandro - é desejado. Estes dados também são encontrados na pesquisa de FéresCarneiro (2003), que aponta que a dificuldade de ficar só é mais abordada nas falas masculinas do que nas femininas.

Dos dez jovens entrevistados, somente Bernardo e Fábio não colocam o casamento como um plano de vida, pois não eles dizem não fazer planos. Os outros jovens consideram a instituição matrimonial como muito importante e expressam o desejo de se casar, ainda que não saibam quando isso poderá acontecer. Marcos, o mais novo dos entrevistados, diz estar decidido a se casar em até dois anos com a atual namorada, com quem está junto há nove anos:

Continuo sendo solteiro, mas assim, eu tô buscando as minhas coisas pra eu casar mesmo, eu tô correndo atrás. Eu só não casei ainda, já tenho quem eu quero pra casar, eu só não casei ainda porque eu tô conseguindo a minha casa ainda, tô comprando meu apartamento, entendeu?

Como foi registrado no diário de campo, após a entrevista, é interessante o fato de Marcos expressar convictamente o desejo de se casar e seus investimentos - 
financeiros e emocionais - para o matrimônio. No entanto quando questionado como ele se sentia sendo solteiro, respondeu: Eu, na verdade, tô partindo pra um casamento, né?

Apesar de ser o mais novo entrevistado até então (26 anos), é o que namora há mais tempo, nove anos. Esse período de relacionamento, bastante superior ao dos outros entrevistados que têm namorada, parece dar uma segurança maior à decisão de se unir com a parceira.

Ainda que Bernardo, Eduardo, Leandro, Guilherme e Fábio tenham pais separados, para eles o casamento é encarado como algo de muita importância na vida de um homem. O fato de os pais não estarem juntos parece não influir de forma negativa no desejo desses jovens se casarem; tampouco considerarem o casamento como uma instituição falida ou desnecessária em suas vidas.

Mas eu não sei ainda até que ponto eu tô já preparado pra casar, né, eu acho que eu quero casar, mas eu preciso ainda ter alguma estabilidade, entendeu, pessoal. Eu acho que o homem, enquanto ele não tá seguro com a condição de provedor, ele tem uma certa dificuldade de se casar. (Guilherme)

Apesar de os depoimentos dos participantes não indicarem se eles vão se casar de fato ou não, há de se dar importância a essas falas que denotam uma projeção futura acerca do casamento, o qual está inserido em seus planos de vida. Mesmo reconhecendo que o divórcio se tornou comum e socialmente aceitável, o que indicaria que existem muitas uniões mal-sucedidas que se dissolvem, os jovens parecem considerar que vale a pena investir em um relacionamento com vistas ao casamento e também permanecer casado.

O divórcio é concebido pelos entrevistados como um recurso a ser utilizado em casos onde a relação realmente não está dando certo, uma vez que é melhor se separar do que manter um casamento falido e infeliz. Os jovens pontuam, entretanto, que não gostariam de se casar e se separar e nesse sentido, enfatizam novamente a seriedade da decisão em realizar uma união:

Eu acho que a hora que não tá dando mais certo, é pra divorciar mesmo, sabe? [...] Tem que ser de consenso entre as partes e, se não deu, paciência [...] Eu não acho que tem que se casar a qualquer custo, que é pra não se divorciar a qualquer custo. (Aluísio)

Eu acho uma coisa natural, entendeu, assim, às vezes você casa e acha que aquilo vai ser legal, tudo, você tem chance de errar, como errar de parceiro. É uma coisa natural, não gosta, não adianta ficar junto, tem que divorciar mesmo, fazer o quê, não vai forçar. (Glauber) 
Ele foi feito, né, ele tá feito aí pra você, se quiser acabar com o casamento, fazer algo legal pra terminar com aquilo e recomeçar. Eu, particularmente não pretendo me separar, quero ficar casado. (Leandro)

Cara, eu acho que a pessoa se equivocou em casar, não soube levar essa vida de responsabilidade, ou talvez achou algum interesse por outra pessoa, o que caracteriza que ela foi imprudente, né, antes de pensar mesmo se era isso que ela queria. Eu acho que a pessoa cometeu um erro e a sociedade achou uma brecha pra ela poder, vamos dizer assim, corrigir um erro que ela possa ter, não é que ela considere um erro. (Eduardo)

Nesse sentido, destaca-se a fala de Eduardo, que considera o divórcio como a anulação de um equívoco. O casamento que não deu certo, para ele, é considerado um erro. Essa fala se afasta de outras expressas pelos jovens, que afirmam que a relação pode não ter sido bem sucedida, mas teve seus aspectos positivos e não foi totalmente fracassada, abrindo a possibilidade da reconstrução de outros relacionamentos.

\subsection{Ser macho, ser homem, homossexuais e travestis}

Eu acho que, tipo, que tem cara que é homem, mas que não é macho (Bernardo)

Pra mim, homem que é homem, que é adulto, assume os seus compromissos, assume a sua vida, sabe? É a responsabilidade sobre os seus atos, é deixar de colocar os seus atos nas mãos dos outros, é deixar de culpar os outros pelo que não deu certo na sua vida, é falar: "Eu fiz merda e eu sou assim e eu vou ter que arcar com isso" (Aluísio)

[...] Eu acho que é um tanto quanto Narciso a relação [dos homossexuais], mas eu respeito, porque o cara gosta tanto de si que ele adora tanto ser homem que ele vê o homem no outro, como a melhor coisa do mundo. (Fábio)

O travesti é um homem que não só ele quer agir como uma mulher, como ele praticamente veste um... Ele coloca o hardware, digamos assim, né, de mulher, coloca peito, às vezes, tira pênis, enfim, né? (Sérgio)

Outro aspecto abordado junto aos entrevistados foi se eles percebiam alguma distinção entre ser macho e ser homem. Nos depoimentos, o estereótipo de macho parece ter sido erigido sobre valores como a impulsividade, agressividade e rusticidade, 
ao passo que a constituição do homem é perpassada por valores como a ética e o respeito; entretanto, às vezes esses dois termos também se confundem, já que podem estar presentes em um mesmo sujeito.

Para os entrevistados, o ser macho, de forma geral, é expresso em comportamentos voltados a própria sobrevivência e ao conflito, em que se lança mão da forca física a fim de se estabelecer uma relação de dominância em relação a um outro geralmente do mesmo sexo - ou ao meio circundante. Outro aspecto do "macho" é que ele na maioria das vezes é concebido sob uma perspectiva negativa pelos participantes, muitas vezes associado a um sujeito violento, distanciado afetivamente das pessoas e que tem posturas inadequadas na sociedade.

Interessante notar que a respeito dessa temática há a presença de elementos que vão ao encontro de uma cultura machista, lado a lado com conteúdos que se dirigem em direção oposta a tal referencial. Para alguns desses jovens, essa ambiguidade de valores gera certa confusão de posições a serem assumidas em relação a temas abordados ao longo das entrevistas.

Ser macho e ser homem? Eu acho que tem muito cara macho que não é homem. Um cara muito machista, puramente machista, daquele que não tira o prato da mesa, daquele que não ajuda a mulher em nada, que não quer que a mulher trabalhe... Isso pra mim não quer dizer que ele é homem, isso é um papel que ele tenta reproduzir pra suportar talvez as próprias angústias, sabe? Eu acho que homem de verdade é aquele que assume compromisso. (Aluísio)

[...] Eu tenho uma visão muito biológica, ser macho é nascer com aquilo lá no meio das pernas, ser homem é a construção social que a gente tem da figura masculina Tem os aspectos culturais que eu te falei, viu, mas você vê que até de cultura pra cultura tem uma variação nisso. (Guilherme)

Macho eu acho que é um cara mais ignorante, não tem muito... Vamos dizer assim, muita noção do que é ser homem de verdade, ele acha... Não sei, o macho pra mim é algo muito, muito baixo, uma pessoa que não tem noção do quê que é realmente ser uma pessoa, ser um indivíduo, né? (Eduardo)

Macho também tá ligado aquele negócio do cara ser durão, de ele ser o machão, de ele ir pra balada e pegar todas, de arrumar briga com todo mundo, esse é o machão. Ele é o cara, ele é o que domina, tal, inclusive as mulheres. Então, ele vai mais pro lado... Eu acho que macho vai mais pro lado animal do homem do que o homem mesmo, de ser um homem de caráter, de ser uma pessoa digna, que respeita, tal, essa eu acho que é a diferença. (Glauber) 
[...] E tem gente que, tipo, "Ah, eu sou macho e...", meu, bate no peito e fala que é macho, que é aquele cara mais quadrado do que o último quadrado [...] É que nem dizem: "Homem macho não chora, não sofre", o caramba que não sofre, não chora, viu? [...] Eu acho que é um estereótipo, homem e macho é tudo a mesma coisa, um mais pra um lado, entendeu, começar pelo heterossexual, o outro aqui, é tudo homem. Todo homem tem um pouco de macho [...] (Leandro)

Os depoimentos acima levantam aspectos ligados à possibilidade da vivência de masculinidades alternativas ao modelo hegemônico. Ao tratar do fato de que os "homens machos" também choram e sofrem, alguns participantes assinalam que os homens devem ser sensíveis e exporem sua emoção, mas ao mesmo tempo, a sensibilidade e a passividade ainda são vistas como atributos femininos. Se se portarem como sensíveis demais, podem ser considerados menos homens e menos machos por seus interlocutores; além disso, a sensibilidade deve estar inscrita dentro de certos limites e associada à força e à racionalidade, predicados essencialmente "masculinos".

O caráter viril associado ao macho fica ainda mais claro quando se pergunta se um homossexual pode ser considerado um macho, ao que quase todos os entrevistados responderam negativamente. Pontuaram que, mesmo portando um corpo masculino, o homossexual tem uma característica que o iguala à mulher, como a atração por outros homens e o relacionamento sexual com eles - independentemente se ele assume uma posição ativa ou passiva no sexo. É esse o critério adotado pelos participantes para não o considerarem macho. Para eles, ser macho é, acima de tudo, relacionar-se sexualmente com fêmeas.

Eu acho que a condição da masculinidade não tá ligada só à questão da genitália, ou se ele é comido ou se ele come, sabe, eu acho que é algo muito maior do que isso. (Aluísio)

Ser macho é ser heterossexual, é isso. Homem pode ser homossexual, o macho não, eu não consigo ver, tipo, mesmo que um cara virar e falar que ele é só ativo, o caralho, ele não é macho pra mim, cara. Homem que pega homem não é macho pra mim. (Bernardo)

Olha, no aspecto biológico, eu diria que é um macho, mas eu não sei te dizer ao certo, são coisas que eu nunca parei pra pensar. Eu respeito a opção, mas talvez eu não colocaria como um homem, entendeu, eu colocaria ele em outra posição, talvez um outro espaço. Também não colocaria como um meio termo, como a maior parte das pessoas tentam passar, ele, ela, é uma outra opção de construção cultural, né, dentro desse aspecto. [...] Tem uma conformação cultural diferente, que leve ele a agir de uma forma diferente da que se espera de um homem. (Guilherme) 
Ainda que haja avanços sociais na aceitação da homossexualidade, esta ainda se apresenta como uma interdição. Talvez uma das razões que explique essa condição seja o fato de a heterossexualidade ser um atributo forte da masculinidade para homens e mulheres. Segundo uma pesquisa realizada em 2002 com uma amostra de 2.364 participantes, há forte rejeição ao homossexualismo masculino (89\%) e também ao feminino (88\%) (ALMEIDA, 2005).

Entretanto, nota-se que nem sempre ocorre a ligação direta entre homem e heterossexualidade, o que levanta a possibilidade de essa orientação hegemônica ter também alternativas concorrentes. $O$ fato de que ainda exista a predominância da heterossexualidade não é impeditivo para que outros posicionamentos alternativos apareçam nos depoimentos:

Eu considero que [o homossexual] é um homem, porque ele tem um corpo de homem, mas que a mentalidade dele é diferente, é, ele sente atração... Agora, isso que é engraçado: ele tem hormônio masculino no corpo. O hormônio masculino é que faz você ter desejo sexual por uma fêmea, pensando assim. Ou seja, se o homossexual, ele tem isso no corpo, por que que ele sente atração por uma mulher? Ou seja, é algo da cabeça dele, ele transforma o corpo dele. (Glauber)

Aí vem um pouco do que parte de ser preconceituoso, não querer ouvir, mas a criação é essa, entendeu, a gente não vive nesse mundo, mas o homossexual é um homem. (Leandro)

Os homossexuais, eles, na minha opinião, eles têm corpo de homem, eles conversam como homem, eles têm cargo de homem, só que eles se relacionam com outros homens. Então, assim, fisicamente, ele é um homem, só que como que eu posso dizer? A personalidade não é de um homem, daí é de uma outra coisa que eu não consigo classificar pra você o que é. (Lucas)

Não é porque o cara, ele gosta de homens, que ele não é um homem, né? Ele tem caráter também, ele tem... Ele tem as vontades dele também, não é por isso que ele vai deixar de ser homem, né? (Marcos)

Vê-se nos discursos acima que o homossexual é considerado um homem para a maioria dos entrevistados, não perdendo com a sua opção sexual a marca da masculinidade. Ainda aparece em algumas falas a diferença entre gay (homossexual homem) e "bicha" (homossexual afetado):

Bicha, viado é aquele todo cheio de trejeitos e tal. Agora o gay, não, o gay cê olha e fala "Putz", cê nem desconfia, né, que o cara é bicha, teoricamente. Eu acho que tem muito gay, até bicha que é mais homem do que muito homem. (Aluísio) 
Alguns entrevistados atribuem um caráter muito negativo ao bicha, no sentido de que consideram que a masculinidade está muito "afetada" pelo feminino, por meio do excesso de trejeitos e de sensibilidade. Aluísio, Bernardo e Leandro pontuam que não tem muita tolerância com o bicha, "afetado", que têm amigos ou conhecidos gays, mas que não abrem muito espaço para o compartilhamento da intimidade:

[...] Às vezes a gente tenta trocar uma ideia, mas acaba caindo mais pra brincadeira, quando o cara quer contar um pouco mais, já mando "Guarda essas coisas pra você, cê quer falar que beijou homem, que transou com homem, não vem com detalhe" (Leandro)

Questionados a respeito da sua opinião sobre os travestis, a maioria dos entrevistados considera-os como um homossexual que se veste de mulher; apesar de, às vezes, também manter relações sexuais com mulheres. O que o define é o desejo de ser mulher, de ter um corpo feminino e de se relacionar sexualmente com homens, independentemente se tem uma postura ativa ou passiva:

[...] O travesti, ele quer ser mulher [...] Eu achava que todo travesti era travesti porque tava juntando dinheiro porque queria fazer uma operação de mudança de sexo [...] Alguns são felizes em, tipo, em ter um pinto e que usam e que gostam de comer caras e tal... (Bernardo)

[...] O homem que se veste de travesti, às vezes acaba fazendo a mesma coisa que o homem que é homossexual [...] Às vezes ele chega mais próximo de querer ser mulher do que o cara homossexual simplesmente, pra mim os dois são homossexuais [...] (Leandro)

Travesti pra mim é um homossexual, porque o cara faz relação sexual com outro homem, então... Pra mim ele não é homem. (Lucas)

Pra mim é uma classe também a parte, pra mim um travesti é um homossexual que se assumiu um pouco mais do que os outros, entendeu? (Guilherme)

Interessante pontuar que alguns entrevistados fazem confusão entre travesti e transexual, afirmando que o primeiro por vezes realiza cirurgia de mudança de sexo, característica do transexual. 


\subsection{O homem atual}

Para os informantes, os homens atualmente ainda guardam semelhanças com os de gerações anteriores, entretanto são apontadas várias diferenças. Para dois jovens, por exemplo, os homens de antigamente têm muito mais garra e são muito mais lutadores do que os atuais. Para outros, os homens atuais são mais liberais e evoluíram, sobretudo na relação com as mulheres, lançando-se em direção a uma parceria mais igualitária e considerando os desejos e necessidades da companheira:

Houve uma evolução muito grande dos homens, principalmente com relação às mulheres. [...] Hoje o homem é muito mais preocupado em dar prazer, por exemplo, num relacionamento sexual com uma mulher, do que antes, antes era mais a questão reprodução mesmo. A questão da inserção da mulher no mercado de trabalho também é uma coisa que eu acho que os homens, a mentalidade dos homens evoluiu muito com relação a isso. (Lucas)

Outro ponto destacado é que o homem de hoje é muito mais competitivo e individualista:

$\mathrm{Eu}$ vejo um homem muito ambicioso, muito competitivo... Eu vejo como menos apegado as pessoas, as famílias[...] Eu vejo ele como mais voltado pra ele mesmo, não sendo pejorativo, mas pensando nele como construção de capital, até como saúde, ou seja, cuidar mais dele mesmo, de alguma forma. (Sérgio)

Então tudo ele procura em relação ao desejo dele, é o sonho dele em primeiro lugar. Então, se ele não for assim, eu acredito que ele não consiga nenhum relacionamento, porque as mulheres também se atraem por homens que vão atrás do próprio ego, eu acho que é uma característica da sociedade. (Glauber)

Para Bernardo, contudo, quem mudou foi a mulher, e não o homem:

É tudo igual, cara, antigamente o homem ia pra casa da namorada, sentava do lado do pai, sentava o pai dela aqui, ele aqui e ela ali, ficava vendo televisão e conversando, só segurando na mãozinha dela, assim, aí o pai saía, ele dava um beijinho nela, aí ele saía e ia pro puteiro. Hoje em dia a gente tá em casa, tá com namorada, ficando com a namorada, o caralho, a gente vai embora, sai e vai pra balada e vai beijar outra. Eu acho que o homem, ele quer tantas mulheres quanto ele possa conseguir. 
Um aspecto semelhante entre o homem atual e o homem de antigamente referese a ter condições de prover uma família, muitas vezes sendo o chefe desta. Para alguns informantes, esse ainda é o modelo de homem buscado pelas mulheres, um homem capaz de sustentar os filhos e que por vezes possui um salário maior do que os rendimentos da companheira.

Ó, eu ainda acredito que o modelo da sociedade atual de homem é aquele que provém financeiramente a família, que a mulher cuida dos filhos, que ele ganha mais do que a mulher, que os filhos são criados preferencialmente pela mulher e ao modo da mulher, e não tanto por ele. Um homem que sai pra, no final de semana e não fala que horas volta $[. .$.$] (Aluísio)$

Nesse sentido, é consensual entre os jovens a necessidade de estabilidade financeira e material, sendo este o primeiro tópico apontado à pergunta: "O que o homem de hoje quer?"

Todos os entrevistados levantam e discutem a importância que o dinheiro adquiriu na sociedade atual e consideram-no uma exigência para o estabelecimento profissional e social. Possuir dinheiro para comprar carros, imóveis, vestir-se bem, frequentar bons restaurantes é fundamental para solidificar sua independência e praticamente uma condição sine qua non para também conquistar mulheres:

[...] Eu acho que hoje em dia o pessoal dá importância demais pra dinheiro, eu acho que o dinheiro hoje em dia... Talvez porque dinheiro compre tudo, porque o cara que tem grana tem namorada, o cara que tem grana tem um carro da hora, e com um carro da hora ele tem mais namoradas, e o cara que tem grana tem um apartamento do caralho e com o apartamento do caralho ele tem mais namoradas. (Bernardo)

[...] Ele quer atrair a atenção, cara. Quer atrair a atenção, quer poder ter dinheiro pra ter um puta de um carro, porque o carro já chama atenção e o dinheiro pra ele poder sentar na mesa do bar e pedir o uísque mais caro, e chamar aquela atenção, e comprar roupa de moda pra sair cheiroso e bonito, tal, tal, tal, pegar a mulher mais gostosa, mais bonita. Muitos dos homens de hoje, é o que querem, vamos dizer assim, esses são os valores iniciais. (Leandro)

Interessante destacar que alguns entrevistados assinalam que o homem de hoje se sente "engolido" (sic) frente a uma sociedade que prioriza os bens materiais em detrimento de outros valores. Sérgio, por exemplo, pontua que a lógica do capital vivenciada em empresas, em que valores como competição se sobrepõem ao respeito ao 
outro - foi transposta para os relacionamentos entre as pessoas, gerando um enfraquecimento da importância das relações e levando ao caos:

O valor que se dá a relacionamento, a família, a um monte de coisa, a própria vida é muito baixo, né? Eu acho que antigamente os homens, as pessoas em si eram mais respeitosas de forma geral[...] Quando você vai em cidades maiores, assim, aí vira a lei do caos. Então, o ser humano não tem mais respeito por ninguém.

Outra indagação feita foi "Do que o homem de hoje tem medo?". Os participantes responderam tal questionamento tratando principalmente do relacionamento entre homens e mulheres, em que emergem o medo de se relacionar com uma mulher muito independente, que ganha mais do que o parceiro, o medo de ser traído, de criar um filho que não é seu. Além disso, a incerteza frente à perda do emprego aparece como um elemento que os angustia.

Ainda se nota uma preocupação na manutenção do status quo referente ao poder masculino, ligado especialmente à capacidade de prover e ser potente sexualmente. Não corresponder a essa exigência que eles mesmos se impõem traz sentimentos de desvalia e inferioridade:

Eu acho que o homem hoje tem muito medo da independência da mulher. E a independência de um ser humano tá muito ligada ao dinheiro [...] Me assustaria muito namorar ou casar com uma mulher que ganha quatro vezes o que eu ganho. Eu ia ficar meio perdido, sabe? (Aluísio)

[...] Eu acho que o homem, o que ele tem medo, o homem tem muito medo de ser rejeitado pelo sexo feminino, eu acho que é uma coisa muito importante de se dizer. (Lucas)

Eu acho que o homem de hoje é muito inseguro, com tudo. Tanto com o trabalho, porque ninguém é seguro do seu trabalho mais, a não ser que você... Mesmo quem é dono... [...] É inseguro com relacionamento, que tem mulheres e mulheres hoje, né, de repente cê fica com uma mulher que cê acha que é a mulher da sua vida e a mulher acaba encontrando um cara que tem um carro melhor que o seu e acaba te deixando.(Glauber)

A gente evoluiu do que vinha vindo, né, mas ainda temos vários medos, por exemplo: de não conseguir ser provedor, o medo de criar filho dos outros [...] Eu acho que todo mundo fica com aquela cisminha de "Será que eu tô cuidando de algo que é meu mesmo?", sempre rola essa neurinha, né? (Guilherme) 
[...] Ele tem o medo que todo homem tem, o medo de ser corno, né, medo de perder o emprego, medo de não ser suficiente quando o patrão pede alguma coisa pra ele, medo de ficar sem grana. [...] Eu tenho o maior medo de não corresponder as minhas próprias expectativas. (Fábio)

Nesse sentido, é importante ressaltar a relevância de tais depoimentos, na medida em que os entrevistados puderam encontrar um espaço para expressar suas inseguranças frente à realidade em que vivem, o receio de se sentirem desvalorizados diante de mulheres muito competentes, o temor de serem traídos e abandonados por elas, o receio não conseguirem se estabelecer profissionalmente.

Dois depoimentos ainda trouxeram essa discussão, ainda que em outros momentos da entrevista, afirmem que o homem atual fica muito inseguro diante da banalização da violência, esta diretamente relacionada ao tráfico de drogas.

Nesse sentido, ambos os informantes ainda mencionaram a precocidade com que os adolescentes atuais experimentam drogas e têm suas primeiras relações sexuais, o que gera muitos problemas familiares e sociais. Outro participante ainda assinala que por vezes reflete se vale a pena ter filhos em um momento tão conturbado, onde as condições da própria sobrevivência da espécie humana no planeta estão ameaçadas.

Depreende-se das falas acima que esses homens têm medos e inseguranças também em relação a si mesmos, de não corresponderem às suas próprias expectativas. Todos eles trabalham e dão um valor fundamental a essa atividade, que os auxilia na constituição da própria identidade enquanto homens. Perder o emprego ou não desempenhar seu ofício a contento pode gerar conflitos e contradições acerca do cumprimento do seu desempenho. 



\section{CONSIDERAÇÕES FINAIS}

As mudanças sociais ocorridas no mundo contemporâneo e, especialmente no Brasil, trouxeram consigo novos códigos de interpretação de gênero, para homens e mulheres. As fronteiras entre os sexos tornaram-se permeáveis e fluidas, em valores tradicionais convivem com novos e este relacionamento nem sempre é pacífico.

Nas últimas décadas, impulsionadas pelo aumento de pesquisas sobre masculinidades, a discussão e a reflexão sobre o homem ganharam novas facetas e temas. Noções e práticas sobre os homens concebidas como dadas, sem um processo de reflexão, estão sendo problematizadas. Hábitos, comportamentos, opiniões, afetos masculinos estão sendo repensados, questionados, mantidos, modificados. Cotidianamente. As masculinidades passam atualmente por um processo de constante construção.

Realizar pesquisas cujos sujeitos são homens não é tarefa das mais fáceis. Homens dizem pouco de si, trazem em seus discursos velhos jargões masculinos e machistas que encobrem suas opiniões reais, expõem sua forma de enxergar o mundo de uma maneira pouco esclarecedora, por vezes. Os participantes desta pesquisa assim o fizeram, em alguns momentos da entrevista.

Entretanto, esses dez jovens que contaram um pouco de suas vidas expressaram como se sentem em relação aos amigos, às mulheres, do que têm medo, quais são suas necessidades. Pontuaram o que os fazem se sentir superiores ou inferiores, o valor que dão ao dinheiro, aos relacionamentos, aos seus valores. Assinalaram que assimilar certas mudanças de paradigmas do masculino e do feminino gera confusões e contradições difíceis de serem conciliadas, em uma realidade tão transitória e tão cheia de oposições na qual estão inseridos. Descortinaram planos, sonhos e projeções futuras.

Os depoimentos colhidos ao longo dessa pesquisa refletem a dificuldade que os homens atuais vivenciam em edificar uma identidade masculina que os faça se sentir seguros de si. O processo de negociação dentro dessa construção é extremamente delicado, uma vez que envolve diálogos e confrontos entre diferentes discursos dos quais são interlocutores.

A identidade masculina, segundo eles, ainda precisa ser justificada, provada, por reiteradas vezes. Ainda há o temor de serem considerados homossexuais, contudo estes 
homens querem se sentir mais livres para expressar sua subjetividade, seus sentimentos, suas dúvidas, seus desejos, sem parecerem sensíveis demais.

É difícil, ainda, definir até aonde vai o limite para a exposição de seus afetos. Não querem ser confundidos com mulheres e homossexuais, apesar de incorporarem valores considerados mais femininos, como a sensibilidade e a dedicação afetiva utilizados, inclusive, na conquista das mulheres.

Observou-se, também, um grande receio de serem superados por elas. Superados no tocante ao valor do salário, ao poder, à capacidade para o trabalho, ao número de parceiros sexuais, às realizações pessoais. Entendê-las e aceitar certas posturas delas ainda é algo intricado de ser realizado. São capazes de reconhecer muitas das transformações pelas quais elas passaram, seus efeitos na sociedade e nos relacionamentos. Admiram sua sensibilidade em seu modo de enxergar a realidade. Mas ainda têm problemas em como se comportar diante de mulheres independentes, "descoladas", bonitas, inteligentes e ricas.

Esses jovens, assim como muitos outros, estão em busca de sua masculinidade. Tecem críticas aos modelos tradicionais masculinos, não se identificam com o machista prepotente nem querem ser considerados anti-heróis. O machão, para eles, é um tipo ultrapassado - apesar de, em alguns momentos de seus discursos e práticas, ele reaparecer de forma encoberta e disfarçada. Nem todos se enxergam dentro do modelo tradicional nem no modelo contemporâneo de masculinidade e vão transitando entre estes espaços da forma como podem, conseguem e desejam, dentro de sua singularidade que não é totalmente abarcada por nenhum destes estereótipos.

Para alguns deles, a casa dos pais ainda oferece proteção e protela a assunção de responsabilidades domésticas e conjugais. Permite que a "vida de solteiro" seja mais leve e sem tantas obrigações. O casamento ainda é visto com reservas, com dúvidas e receios. Receios a respeito do relacionamento na vida matrimonial, da assunção de responsabilidades, da perda de espaços, dos prejuízos da liberdade com família e amigos, da construção de uma vida em comum. E de como vão se dar todos esses processos dentro de uma só conjugalidade. Eles também têm desejos. De constituir uma família, de ter filhos, de transmitir seu legado, de construir um bom patrimônio.

Os entrevistados ainda lutam por responder a um ideal de homem, ancorado em valores viris, no desempenho sexual, no acúmulo de dinheiro, status e fama. Segundo eles, não passam muito tempo em academias se exercitando exaustivamente, não utilizam esteróides e anabolizantes, não tomam Viagra para manter relações sexuais. A 
respeito da "pílula azul”, somente Sérgio referiu ter feito uso dela. Os demais negaram, alguns deles disseram que usariam por curiosidade - e não por necessidade. A maioria deles associa o uso do Viagra por jovens da mesma faixa etária a uma insegurança sobre a própria capacidade sexual, uma falta de confiança em si mesmo e no seu potencial viril.

Essa insegurança, tão presente no cotidiano masculino, apareceu revestida por racionalizações, justificações e contradições. A maioria deles estabeleceu uma relação entre mulheres e dinheiro, em que ter dinheiro é igual a ter mulheres,ou seja, possuir um bom carro, um bom apartamento, um bom salário é sinônimo de possuir mulheres.

Essas e outras falas dos pesquisados indicam que, mesmo tentando subverter certos paradigmas masculinos, eles acabam, muitas vezes, se rendendo ao modelo vigente de comportamentos e hábitos.

Os comportamentos sexuais podem ter se transformado, aproximando-se de uma igualdade entre os gêneros, mas o discurso sobre o sexo resiste a mudanças. Os discursos dos jovens pesquisados afirmam e reiteram as diferenças de gênero, apesar de muitas vezes seus comportamentos negarem esta diversidade. A dupla moral sexual ainda está muito presente nas falas encontradas, em que comportamentos apresentados pelos homens são permitidos, incentivados, elogiados e aplaudidos; as mesmas posturas, realizadas por mulheres, são criticadas, rechaçadas e abominadas.

Para Goldenberg (2010), os homens possuem uma visão prática da intimidade, uma intimidade objetiva; as mulheres, uma percepção reflexiva da intimidade, uma intimidade reflexiva. Os homens se queixam da falta de compreensão de suas companheiras, sentem-se injustamente cobrados por não corresponderem às demandas excessivas das mulheres, as quais estão sempre insatisfeitas; elas, por sua vez, reclamam da falta de intimidade com o parceiro, uma forma mais profunda de comunicação, diálogo, de entrega amorosa e emocional.

A intimidade para esses jovens não é um constructo único, ela tem níveis e condições, dependendo de quem é seu interlocutor e qual a confiança depositada neste. Para cada nível na hierarquia da intimidade, mais diálogo, mais profundidade, mais compartilhamentos. A intimidade também envolve temáticas secretas. Segredos para outrem e, especialmente, segredos para si mesmos. Há assuntos que devem ser resguardados, protegidos, ditos somente para eles próprios. A intimidade consigo mesmos também abrange coisas que interessam somente a eles. 
E, paulatinamente, eles vão estabelecendo contornos mais definidos de sua identidade, sua subjetividade, suas concepções sobre relacionamentos. As relações pessoais podem se constituir como espaços de intimidade, possibilitando a reflexão sobre si mesmos. Ainda que esta reflexão ocorra de forma muito incipiente em alguns aspectos, permite que eles se reconstruam, se reavaliem e revisem as escolhas que realizam diariamente em suas vidas. 


\section{REFERÊNCIAS BIBLIOGRÁFICAS ${ }^{1}$}

ABERASTURY, A. Adolescência. Porto Alegre: Artes Médicas, 1983.

AHRNDT, S. Distress in response to infidelity: an examination of the evolutionary perspective. University of Winsconsin, Milwaukee. Thesis Proposal, 2005.

ALMEIDA, A. Marido: quando você vai fazer sexo anal comigo? Mulher: vou pensar no assunto. Inteligência, n. 29, p. 67-78, 2005.

ALMEIDA, T. Ciúme romântico e infidelidade amorosa entre paulistanos: incidências e relações. 2007. Dissertação (Mestrado em Psicologia) - Instituto de Psicologia, Universidade de São Paulo, São Paulo.

ANUÁRIO ESTATÍSTICO DO RIO DE JANEIRO. Centro de Informações e Dados do Rio de Janeiro. Rio de Janeiro: Fundação Cide, 2004.

ARAÚJO, M. F. Diferença e igualdade nas relações de gênero: revisitando o debate. Revista de Psicologia Clínica, v. 17, n. 2, p. 41-52, 2005.

AUGÉ, M. Não lugares: introdução a uma antropologia da supermodernidade. Campinas: Papirus, 2005.

BADINTER, E. XY: sobre a identidade masculina. 2. ed., Rio de Janeiro, 1993.

BEAUVOIR, S. O segundo sexo. Rio de Janeiro: Nova Fronteira, 1980.

BÉJIN, A. O casamento extraconjugal dos dias de hoje. Sexualidades ocidentais. São Paulo: Brasiliense, 1987.

\footnotetext{
${ }^{1}$ De acordo com a Associação Brasileira de Normas Técnicas. NBR 6023
} 
BERQUÓ, E. (1998). Arranjos familiares no Brasil: uma visão demográfica. NOVAIS, F. A. (coord.); SCHWARCZ, L. M. (org.). História da vida privada no Brasil: contrastes da intimidade contemporânea. São Paulo: Companhia das Letras, 1998.

BILAC, E. D., OLIVEIRA; M. C. F. A.; MUSZKAT, M. Homens, mulheres e famílias: reproduzindo imagens. XXIV Encontro Anual da ANPOCS (mimeo), 2000.

BILAC, E. D. Convergências e divergências nas estruturas familiares no Brasil. Ciências sociais hoje. São Paulo: ANPOCS/VÉRTICE, 1991.

BLY, R. João de Ferro. Rio de Janeiro: Campus, 1991.

BOGDAN, R. C.; BIKLEN, S. K. Notas de campo. BOGDAN, R. C.; BIKLEN, S. K. Investigação qualitativa em educação - uma introdução à teoria e aos métodos. Porto: Porto Editora, 1994.

BOURDIEU, P. Razões práticas. Campinas: Papirus, 1996. A dominação masculina. Educação \& Realidade, v. 20, n. 2, p.133-184, 1995. O sentimento da honra na sociedade cabília. PERISTIANY, J. G. Honra e vergonha: valores das sociedades mediterrânicas. $2^{a}$ ed., p. 159-195. Lisboa: Fundação Calouste Gulbenkian, 1988.

Outline of a theory of practice. Cambridge: Cambridge University of Press, 1977.

BORIS, G. D. J. B. Falas masculinas ou ser homem em Fortaleza: Múltiplos recortes da construção da subjetividade masculina na contemporaneidade. 2000. Tese (Doutorado em Psicologia), Universidade Federal do Ceará, Fortaleza, Brasil.

BUTLER, J. Gender trouble: feminism and the subversion of identity. New York and London: Routledge, 1990. 
CAMPOLIM, S.; LIMA, L. T. O. Enquanto as mulheres mandam, os homens fazem o que têm vontade. $2^{a}$ ed. São Paulo: Globo, 1998.

CARRIGAN, T; CONNELL, B.; LEE, J. Toward a new sociology of masculinity. Theory and Society, v. 14, n. 5, p.551-603, 1985.

CASTELLS, M. O poder da identidade. V. 2. São Paulo: Paz e Terra, 1999.

CASTORIADIS, C. Para si e subjetividade. PENA-VEJA, A.; NASCIMENTO, E. P. (orgs.) O pensar complexo. Edgar Morin e a crise da modernidade. Rio de Janeiro: Garamond, 1999.

CONNELL, R. W. Masculinities. University of California Press, Berkeley - Los Angeles, 1995a.

. Gender and power: society, the person and sexual politics. Stanford: Stanford University Press, 1987.

COSTA, J. F. O referente da identidade homossexual. PARKER, R.; BARBOSA, R. M. (Org.). Sexualidades brasileiras. Rio de Janeiro: Relume Dumará, 1986.

DURHAM, E. R. Família e reprodução humana. DURHAM. E. R. et al. Perspectivas antropológicas da mulher 3. Rio de Janeiro: Jorge Zahar, 1983.

ELIAS, N. O Processo civilizador. Rio de Janeiro: Jorge Zahar, 1994.

ERIKSON, E. Identidade, Juventude e Crise. Rio de Janeiro: Jorge Zahar, 1972.

FÉRES-CARNEIRO, T. Conjugalidade dos pais: possíveis influências no projeto de casamento dos filhos. Anais do Simpósio Nacional de Psicologia Social do Desenvolvimento. Vitória: UFES/UNB/UFPE (PROCAD), p. 89-97, 2005. 
Construção e dissolução do laço conjugal na psicoterapia de casal. In FÉRESCARNEIRO, T. (org.) Família e casal: arranjos e demandas contemporâneas. Rio de Janeiro: Nau Editora, 2003.

Casamento contemporâneo: construção da identidade conjugal. FÉRESCARNEIRO, T. (org.). Casamento e família: do social à clínica. Rio de Janeiro: Nau Editora, 2001.

Casamento contemporâneo: o difícil convívio da individualidade com a conjugalidade. Psicologia Reflexão e Crítica, v. 11, n. 2, p. 379-394, 1998.

FOLHA DE SÃO PAULO, 07/10/2007. Casados são a maioria no país, aponta pesquisa. Disponível em <http://datafolha.folha.uol.com.br>. Acesso em 10 de out 2007.

FONSECA, C. Quando cada caso não é um caso: pesquisa etnográfica e educação. Revista Brasileira de Educação, jan/fev/mar/abr, n 10, 1999.

FULLER, N. Identidades masculinas. Lima: Fondo Editorial de la Pontifícia Universidad Católica del Perú, 1997.

GARBOGGINI, F. B. O homem na publicidade da última década. Uma cultura em mutação. Educar, n. 26, p. 99-114. Curitiba: Editora UFPR, 2005.

GARCIA, S. Homens na Intimidade. Masculinidades contemporâneas. Ribeirão Preto: Holos, 2006.

GIDDENS, A. A vida em uma sociedade pós-tradicional. BECK, U.; GIDDENS, A.; LASH, S. Modernização reflexiva: política, tradição e estética na ordem social moderna, p. 73-134. São Paulo: Editora da Universidade Estadual Paulista, 1997.

A Transformação da Intimidade. Oeiras: Celta Editora, 1995. 
As consequências da modernidade. Tradução de Raul Fiker. São Paulo: Editora da Universidade Estadual Paulista, 1991.

GIFFIN, K. A inserção dos homens nos estudos de gênero: contribuições de um sujeito histórico. Ciência e Saúde Coletiva, v. 10 n. 1, p. 47-57, 2005.

GOFFMAN, E. Estigma. Notas sobre a manipulação da identidade. Rio de Janeiro: Zahar, 1978.

GOLDBERG, H. O macho secreto: superando bloqueios no caminho da intimidade. Rio de Janeiro: Rosa dos Tempos, 1994.

GOLDENBERG, M. Novas famílias nas camadas médias urbanas. Terceiro Encontro de Psicólogos Jurídicos. Rio de Janeiro: EMERJ / ESAJ, p. 18-26, 2003.

Sobre a invenção do casal. Estudos e Pesquisa em Psicologia, v. 1, n. 1, p. 89-104, 2001.

- O macho em crise: um tema em debate dentro e fora da academia. GOLDENBERG, M. (org.) Os novos desejos: das academias de musculação as agências de encontros. Rio de Janeiro: Editora Record, 2000.

Ser homem, ser mulher: dentro e fora do casamento. Estudos antropológicos. Rio de Janeiro: Editora Revan, 1991.

GOMES, R. Sexualidade masculina e saúde do homem: proposta para uma discussão. Ciência \& Saúde Coletiva, v. 8, n. 3, p. 825-829, 2003.

GOMES, R.; NASCIMENTO, E. F.; REBELlO, L. E. F. S.; ARAÚJO, F. C. As arranhaduras da masculinidade: uma discussão sobre o toque retal como medida de prevenção do câncer prostático. Ciência e Saúde Coletiva, v. 13, n. 6, p. 1975-1984, 2008.

GOMES, R.; NASCIMENTO, E. F.; ARAÚJO, F. C. Por que os homens buscam menos os serviços de saúde do que as mulheres? As explicações de homens com baixa 
escolaridade e homens com ensino superior. Cadernos de Saúde Pública, v. 23, n. 3, p. 565-574, 2007.

GOMES, R.; NASCIMENTO, E. F. A produção do conhecimento da saúde pública sobre a relação homem-saúde: uma revisão bibliográfica. Cadernos de Saúde Pública, v. 22, p. 901-911, 2006.

GONZÁLEZ-REY, F. L. Pesquisa qualitativa em Psicologia: caminhos e desafios. São Paulo: Pioneira Thompson Learning, 2002.

GRIMBERG, M. Sexualidad y relaciones de género: una aproximación a la problemática de la prevención del VIH/SIDA en sectores populares de la ciudad de Buenos Aires. Cuadernos Médico Sociales, n. 75, p. 65-76, 1999.

HACKER, H. M. The new burdens of masculinity. Marriage and family living, v. 19, n. 3, p. 227-233, 1957.

HARDY, E.; JIMÉNEZ, A. L. Masculinidad y género. Salud y género. Chile, 2000.

HEILBORN, M. L. Dois é par: gênero e identidade sexual em contexto igualitário. Rio de Janeiro: Garamond, 2004.

HENRIQUES, C. R.; JABLONSKI, B.; FÉRES-CARNEIRO, T. A “Geração Canguru”: algumas questões sobre o prolongamento da convivência familiar. Psico, v. 35, n. 2, p. 195-205, 2004.

INSTITUTO BRASILEIRO DE GEOGRAFIA E ESTATÍSTICA. IBGE divulga estatísticas do Registro Civil de 2003. Disponível em $<$ http://www.ibge.gov.br/english/presidencia/noticias/noticia_visualiza.php?id_noticia= 283\&id_pagina=1>. Acesso em 10 out. 2010.

As mulheres no alvo das políticas públicas brasileiras. Disponível em <http://www.ibge.gov.br/home/presidencia/noticias/noticia_visualiza.php?id_noticia=6 05\&id_pagina=1>, acesso em 07 abr. 2010. 
INSTITUTO BRASILEIRO DE OPINIÕES PÚBLICAS E ESTATÍSTICA (IBOPE). Novo Homem é o tema do IBOPE no MaxiMídia 2007. Disponível em <http://www.ibope.com.br/>, acesso em 10 out. 2007.

INSTITUTO DE PESQUISA DATAFOLHA. Família fica ainda mais importante

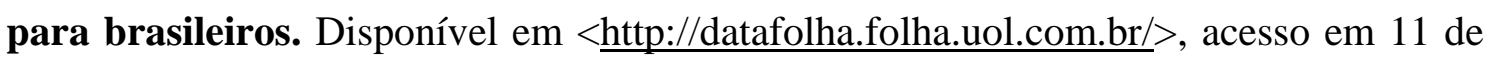
out. 2007.

JABLONSKI, B. Até que a vida nos separe: a crise do casamento contemporâneo. Rio de Janeiro: Agir, 1998.

JUSTO, J. S. O "ficar" na adolescência e paradigmas de relacionamento amoroso da contemporaneidade. Revista do Departamento de Psicologia - UFF, v. 17, n. 1, p.6177, 2005.

KIMMEL, M. S. (ed.). Changing men: new directions in research on men and masculinity. Newbury Park/Beverly Hills/London/New Delhi: Sage Focus Publications, 1998.

KNOBEL, M. A Síndrome da Adolescência Normal. ABERASTURY, A.; KNOBEL, M. A adolescência normal, p. 24-62. Porto Alegre: Artes Médicas, 1981.

KORIN, D. Nuevas perspectivas de género en salud. Adolescencia Latinoamericana, v. 2, p. 67-79, 2001.

KORIN, D. E.; FAGAN, J. What about Men These Days? The Invisibility of Gender. Journal of General Internal Medicine, v. 11, p. 381, 1996.

LASCH, C. Refúgio num mundo em coração. A Família: Santuário ou Instituição Sitiada? Rio de Janeiro: Paz e Terra, 1991.

LÉVI-STRAUSS, C. A família. SHAPIRO, H. L. (org.) Homem, cultura e sociedade. Rio de Janeiro: Fundo de Cultura, 1956. 
LOURO, G. Gênero, sexualidade e educação - uma estrutura pós-estruturalista. Petrópolis: Vozes, 1998.

LYRA, J. Paternidade adolescente: da investigação à intervenção. ARRILHA, H. A. M.; UNBEHAUMS, S.; MEDRADO, B. Homens e masculinidades: outras palavras ECOS, p. 185-214. São Paulo: Editora 34, 1998.

MEDRADO, B. O masculino na mídia: repertórios sobre masculinidade na propaganda televisiva brasileira. 1997. Dissertação (Mestrado em Psicologia) Pontifícia Universidade Católica de São Paulo, São Paulo.

A masculinidade nos comerciais de televisão. Caxambu: XV Reunião Anual da ANPOCS, 1996.

MINISTÉRIO DA SAÚDE E CENTRO BRASILEIRO DE ANÁLISE E PLANEJAMENTO (2008). Pesquisa Nacional de Demografia e Saúde da Criança e da Mulher $2006 \quad-\quad$ Relatório Final. Disponível em $\langle$ http://bvsms.saude.gov.br/bvs/pnds/img/relatorio_final_pnds2006.pdf $>$, acesso em 20 set. 2010.

MUCCHIELLI, A. L'identité. Paris: PUF, 1986.

MUSZKAT, M. E. Violência de gênero e paternidade. ARRILHA, H. A. M., UNBEHALMS, S.; MEDRADO B. Homens e masculinidades: outras palavras ECOS, pp. 215-234. São Paulo: Editora 34, 1998.

NASCIMENTO, E. F.; GOMES, R. Marcas identitárias masculinas e saúde de homens jovens. Cadernos de Saúde Pública, Rio de Janeiro, v. 24, n. 7, p. 1556-1564, 2008.

NEGREIROS, T. C. G. M. A Nova Velhice: uma visão multidisciplinar. Rio de Janeiro: Revinter, 2002.

NEGREIROS, T. C. G. M.; FÉRES-CARNEIRO, T. Masculino e feminino na família contemporânea. Estudos e Pesquisas em Psicologia, ano 4, n. 1, p. 34-47, 2004. 
NOLASCO, S. Identidade masculina: um estudo sobre o homem e classe média. 1988. Dissertação (Mestrado em Psicologia), Pontifícia Universidade Católica do Rio de Janeiro, Rio de Janeiro.

O mito da masculinidade. Rio de Janeiro: Rocco, 1993.

OLIVEIRA, M. C.; BILAC, E.; MUSZKAT, M. It's not my fault I wasn't born a woman: contraception among middle-class brazilian men (mimeo), 2000.

OLIVEIRA, P. P. A construção social da masculinidade. Belo Horizonte: Editora UFMG, 2004.

Discursos sobre a masculinidade. Estudos Feministas, v. 6, n. 1, p. 91-112, 1998.

OLIVEIRA, R. C. Identidade, etnia e estrutura social. São Paulo: Pioneira, 1976.

OLIVEIRA, Z. L. C. A provisão da família: redefinição ou manutenção dos papéis? ARAÚJO, C.; SCALON, C. (orgs.) Gênero, família e trabalho no Brasil. Rio de Janeiro: Editora FGV, 2005.

ORTIZ, R. Cultura brasileira e identidade nacional. São Paulo: Brasiliense, 1985.

ORTNER, S. B. Subjetividade e crítica cultural. Horizontes Antropológicos, n. 28, p. 375-405, 2007.

PARKER, R. Corpos, Prazeres e Paixões: A Cultura Sexual no Brasil Contemporâneo. São Paulo: Best Seller, 1991.

PASCHOALICK, R. C.; LACERDA, M. R.; CENTA, M. L. Gênero masculino e saúde. Cogitare Enfermagem, v. 11, n. 1, p. 80-86, 2006. 
Famílias de classes populares: socialização e identidade masculina. Cadernos de pesquisa NEP, n. 1 e 2, p. 25-34, 1997.

PAUL, P. The Permaparent. Psychology Today, v. 36, n.5, p. 40-53, 2003.

POITEVIN, A. Enfants de familles recomposées. Rennes: Presses Universitaires de Rennes, 2006.

RIOS, I. C. O amor nos tempos de Narciso. Interface, v. 12, n. 25, p. 421-426, 2008.

RODRIGUES, A. Atribuição de Causalidade ao Sucesso e ao Fracasso como Fator Mediador de Reação Emocional e de Expectativa de Comportamento. Arquivos Brasileiros de Psicologia. Rio de Janeiro: FGV, v. 36, n. 4, p. 12-25, 1984.

SAFFIOTTI, H. I. B. Gênero, patriarcado, violência. São Paulo: Fundação Perseu Abramo, 2004.

SALEM, T. O Casal Igualitário: Princípios e Impasses. Revista Brasileira de Ciências Sociais, v. 9, n. 3, p. 24-37, 1989.

SANTOS, B. de S. Os processos da globalização. SANTOS. B. de S. (org.) A globalização e as Ciências Sociais, pp. 25-102. São Paulo: Cortez, 2002.

Pela mão de Alice: o social e o político na pós-modernidade. Porto: Afrontamento, 1994.

SCOTT, J. Gênero: uma categoria útil de análise histórica. Educação \& Realidade, v. 20, n. 2, p. 71-99, 1995.

SILVA, M. A. M; MELO, B. M.; APPOLINÁRIO, A. P. A família tal como ela é nos desenhos de crianças. Ruris, v. 1, n. 1, p. 105-155, 2007.

SILVA, S. G. A crise da masculinidade: uma crítica à identidade de gênero e à literatura masculinista. Psicologia Ciência e Profissão, v. 26, n. 1, p. 118-131, 2006. 
SINGLY, F. Sociologia da família contemporânea. Rio de Janeiro: Editora FGV, 2007.

O nascimento do indivíduo individualizado e seus efeitos na vida conjugal e familiar. PEIXOTO, C. et al. Família e individualização. Rio de Janeiro: FGV, p.13$19,2000$.

TEIXEIRA, E. G. Solidão, a busca do outro na era do eu: estudo sobre sociabilidades na modernidade tardia. Sociologia, v. 35, p. 31-47, 2001.

THÉRY, I. Introduction génerale: le temps des recompositions familiales. MEULDERS-KLEIN, M. T.; THÉRY, I. (orgs.). Les recompositions familiales aujourd'hui. Paris: Nathan, 1993.

TOLSON, A. Os limites da masculinidade. Lisboa: Assírio e Alvim, 1983.

VELHO, G. Subjetividade e sociedade: uma experiência de geração. Rio de Janeiro: Jorge Zahar, 1986.

WANG, M. L. Os últimos românticos? Um estudo sobre masculinidade e expressão do sentimento amoroso. 2004. Dissertação (Mestrado em Psicologia), Departamento de Psicologia, Pontifícia Universidade Católica, Rio de Janeiro.

WANG, M. L; JABLONSKI, B.; MAGALHÃES, A. S. Identidades masculinas: limites e possibilidades. Psicologia em Revista, v. 12, n. 19, p. 54-65, 2006.

WELZER-IANG, L. A construção do masculino - dominação das mulheres e homofobia. Estudos Feministas, v. 9, n. 2, p. 460-482, 2001.

WILM, M. G. A representação masculina em anúncios: uma observação sobre as diferenças na abordagem do gênero. XXV Congresso Brasileiro de Ciências da Comunicação - Salvador/BA - 01 a 05 Set 2002. 
ZELDIN, T. História Íntima da Humanidade. Lisboa: Editorial Teorema, 1994. 


\section{ANEXO A - Roteiro de Entrevista}

Dados pessoais (Nome, Idade, Nível de instrução, Profissão, Ocupação, Renda mensal) Com quem mora?

Há quanto tempo?

\section{Infância e Adolescência}

Como foi a sua infância? (com quem vivia, com quem brincava, as brincadeiras preferidas, o que não gostava de fazer, como era a escola, como era o relacionamento com os pais, irmãos e amigos...)

Como foi a adolescência? (o que fazia, como era o relacionamento com a família, dificuldades, sonhos, paqueras, relacionamento com os meninos e as meninas de sua idade, amigos, amigas, como foi vivenciar essa fase...)

\section{A condição masculina}

O que significa ser homem para você?

O que torna alguém um homem? O que é necessário para se construir um homem?

O que diferencia um homem de uma mulher? Por quê?

Você vê diferença entre ser macho e ser homem? (Se sim, quais? Por quê?) (Se não, por quê?)

Você considera que um homossexual é um homem? Por quê?

Qual é a sua opinião sobre os travestis?

Quais as situações mais comuns que ocorrem com homens? (Por quê, como, onde...)

Há situações que você considera que só aconteçam com homens? Quais? Você já passou por alguma delas? Qual o efeito que elas causaram em sua vida?

Você considera que certas situações são mais fáceis para os homens do que para as mulheres? (Se sim, quais? Por quê?) (Se não, por quê?)

Você considera que algumas situações são mais fáceis para as mulheres do que para os homens? (Quais? Por quê?)

Quais são as melhores situações que acontecem com homens? E as piores?

Você já passou por alguma experiência em que se sentiu inadequado enquanto homem? (Se sim, qual? O que sentiu?)

Você acha que os homens de hoje são diferentes dos homens de antigamente? (Se sim, em quê? Por quê?) (Se não, por quê?) O que contribuiu para essas mudanças?

Que valores você acha que são os mais importantes para sua formação enquanto homem? E os menos importantes? Por quê?

Na sua opinião, como é o homem da sociedade atual? (O que faz, como faz, o que pensa, quais as necessidades, medos, sonhos, desejos...)

Como é para você ser homem no mundo de hoje? (É possível expressar sentimentos, medos e dúvidas com as pessoas com quem convive? O que pensa sobre isso? )

Quais as vantagens de ser homem? E as desvantagens?

Se pudesse mudar algo em você, o que mudaria? E o que manteria em você? 


\section{Relações afetivo-sexuais}

\section{Amigos}

Você tem amigos? Como é a relação com eles? O que fazem juntos? Sobre quais assuntos conversam? Como é a conversa com eles?

Compartilha com eles suas questões pessoais? Por quê? Como é?

Quais são os pontos positivos dessas relações? E os negativos? A que os atribui?

O que é necessário para se construir uma amizade com homens?

Participa de algum grupo ou atividade que sejam constituídos apenas por homens? $\mathrm{O}$ que fazem? Como se sente nesse ambiente?

Já se sentiu constrangido em alguma situação frente a outros homens? Como foi?

Numa festa, por exemplo, você apenas se aproxima mais de grupos masculinos ou femininos? Por quê?

Você acha que seu comportamento é o mesmo quando está em grupos masculinos e quando está em grupos femininos? (Por quê, como...)

\section{Amigas}

Você tem amigas? Como é a relação com elas? O que fazem juntos? Sobre quais assuntos conversam?

Compartilha com elas suas questões pessoais? Por quê? Como é?

Quais são os pontos positivos dessas relações? E os negativos? A que os atribui?

Você percebe alguma diferença de sua relação com as amigas da relação com seus amigos? (Em que consiste esta diferença e a que a atribui)

Você acha que a sua relação com elas se diferencia dos seus relacionamentos afetivosexuais? (Em que há diferenças e como lida com elas)

O que é necessário para se construir uma amizade com mulheres?

Já se sentiu constrangido em alguma situação frente às mulheres? Quando? Como foi?

Você já se interessou por uma amiga? (Como foi, o que sentiu, qual o efeito na amizade... Aconteceu o inverso?)

\section{Mulheres, Namoradas e "Ficantes"}

Tem namorada? (Caso sim, há quanto tempo, como se conheceram, como é a relação com ela, Quais os pontos positivos/vantagens e pontos negativos/desvantagens/ dificuldades da relação)

Já teve outras namoradas? (Como foi o namoro, quais as razões do término, o que ficou do relacionamento)

$\mathrm{O}$ que você considera fundamental para um relacionamento?

Qual a sua opinião sobre o "ficar"? (Já viveu essa experiência? Como foi?)

Que imagem você tem das mulheres atualmente? Elas são diferentes das mulheres de antigamente? (Caso sim, por quê? $O$ que você acha que contribuiu para essas mudanças?)

(Caso não, por quê?)

$\mathrm{O}$ que mais lhe agrada em uma mulher? $\mathrm{O}$ que mais lhe chama a atenção? $\mathrm{O}$ que mais lhe desagrada?

O que você espera encontrar em uma companheira?

Você já teve relações sexuais? Como foi a primeira vez? Como avalia a sua vida sexual atualmente? 
Qual o significado que você acha que as relações sexuais têm na vida de um homem? E na sua vida atual?

O que você acha dos homens jovens que utilizam o Viagra em suas relações sexuais? (Conhece alguém que o fez/faz? O que sabe sobre o tema?)

\section{Casamento}

Como você se sente sendo solteiro? Quais as vantagens da vida de solteiro? E as desvantagens?

O que você pensa, sente, quando ouve a palavra casamento?

Qual o significado que você acha que o casamento tem na vida de um homem? O que representa o casamento?

O casamento faz parte do seu projeto de vida? Por quê?

Quando pretende se casar?

Quais as vantagens que você considera que vida de casado possui? E as desvantagens?

Que valores você espera encontrar em uma companheira? Por quê?

$\mathrm{O}$ que você considera fundamental para tomar a decisão de se casar? O que leva um homem a se casar?

Você acha que há diferenças entre os casamentos de antigamente e os casamentos de hoje? (Por quê, a que atribui)

Você acha que o casamento tem o mesmo valor para homens e mulheres? (Por quê?)

O casamento civil é importante pra você? (Por quê?)

O casamento religioso é importante pra você? (Por quê?)

Qual a sua opinião sobre o divórcio?

O que você acha da situação de um homem ser sustentado por uma mulher? Já passou (ou passa) por essa condição? (Caso sim, como foi (é)?

\section{Filhos}

Você tem filhos? (Caso sim, quantos, qual a idade e sexo de cada um)

Como você caracteriza sua relação com seus filhos?

Como você compara sua relação com seu pai e sua relação com seus filhos?

Eles são mais próximos de você ou da mãe deles?

Como justifica isto?

Você se percebe repetindo ou tenta repetir as atitudes de seu pai com você em sua relação com seus filhos ou tenta agir diferente dele? Por quê?

Na sua relação com seus filhos, há toques e manifestação de carinho?

Houve alguma mudança com o tempo?

Há alguma diferença entre o seu contato com seus filhos e com suas filhas? De que maneira esta diferença se manifesta?

(Caso não, você pensa em ter filhos? Por quê?)

Que valores você considera importantes para um homem ser um bom pai?

Qual a sua opinião sobre técnicas de fertilização in vitro? E a adoção?

\section{Família}

Que valores você julga serem essenciais para a constituição de uma família? Por quê?

Quais são as vantagens de se constituir uma família? E as desvantagens?

Qual a importância de se ter uma família atualmente? 
Qual o papel você considera que o homem deva ocupar na família? E a mulher? Você acha que existem atividades domésticas só de homem ou só de mulher? Você acha que o homem deve ajudar a mulher em tarefas de casa e cuidado dos filhos? Por quê? Como? 
ANEXO B - Aprovação do projeto de pesquisa junto ao Comitê de Ética da Faculdade de Filosofia, Ciências e Letras de Ribeirão Preto 


\section{ANEXO C - Termo de Consentimento Livre e Esclarecido}

\section{TERMO DE CONSENTIMENTO LIVRE E ESCLARECIDO}

Meu nome é Bruno de Paula Rosa, RG MG 12157205 e sou aluno do programa de PósGraduação em Psicologia da Faculdade de Filosofia, Ciências e Letras de Ribeirão Preto da Universidade de São Paulo (USP).

Você está sendo convidado a participar, como voluntário, da pesquisa "Jovens solteiros: identidade, subjetividade e concepções acerca do casamento", que tem como objetivo investigar como homens solteiros de camadas médias, de 25 a 35 anos, concebem sua masculinidade, como vivenciam e expressam seus sentimentos, quais as expectativas a respeito de relacionamentos afetivo-sexuais, como o "ficar", o namoro e o casamento, qual o modelo de mulher desejado como esposa e quais as suas concepções e significados sobre casamento e a constituição de uma família.

Se você estiver de acordo, terá de responder a uma entrevista gravada sobre temas como adolescência, masculinidade, relações afetivo-sexuais, namoro, casamento e lazer. Você terá o total direito de se recusar a responder a qualquer pergunta que lhe for feita, sem o risco de qualquer prejuízo.

Você não arcará com nenhum gasto decorrente de sua participação na realização da entrevista e não receberá qualquer espécie de benefício, pagamento ou reembolso pela participação na pesquisa.

É garantida a sua privacidade quanto aos seus dados confidenciais envolvidos na entrevista, serão divulgados somente dados diretamente relacionados aos objetivos da pesquisa. O resultado final da pesquisa será divulgado em seminários, congressos e publicações locais e nacionais; entretanto, a sua identidade será mantida em sigilo.

No caso de você concordar em participar, favor assinar ao final do documento. Sua participação não é obrigatória: a qualquer momento, você poderá desistir de participar, retirando seu consentimento e isso não lhe causará nenhum prejuízo.

Você receberá uma cópia deste Termo de Consentimento onde consta o telefone do pesquisador principal, podendo tirar dúvidas do projeto e de sua participação, entrando em contato comigo pelos telefones (16) 39645595 e (16) 8147 7050, ou ainda pelo endereço: Rua Álvares Cabral, 1152, ap 34, Centro, Ribeirão Preto - SP.

Nome e Assinatura do Pesquisador ResPonsável: Bruno de Paula Rosa

$\mathrm{Eu}$, RG , declaro que li as informações contidas nesse documento, fui devidamente informado(a) pelo pesquisador dos procedimentos que serão utilizados, custo/reembolso dos participantes, confidencialidade da pesquisa, concordando ainda em participar da pesquisa. Foi-me garantido que posso retirar o consentimento a qualquer momento, sem que isso leve a qualquer penalidade. Declaro ainda que recebi uma cópia desse Termo de Consentimento.

\section{LOCAL E DATA:}

NOME E ASSINATURA: 